\title{
Granitoid plutons in peri-Gondwanan terranes of Cape Breton Island, Nova Scotia, Canada: new U-Pb (zircon) age constraints
}

\author{
SANDRA M. BARR ${ }^{1}$, DEANNe VAN ROOYEN², AND CHRIS E. WHITE ${ }^{3}$ \\ 1. Department of Earth and Environmental Science, Acadia University, Wolfville, Nova Scotia B4P 2R6, Canada \\ 2. Department of Mathematics, Physics, and Geology, Cape Breton University, Sydney, Nova Scotia B1P 6L2, Canada \\ 3. Nova Scotia Department of Natural Resources, Box 698, Halifax, Nova Scotia B3J 2T9, Canada \\ ${ }^{*}$ Corresponding author $<$ Sandra.barr@acadiau.ca $>$
}

Date received: 15 October 2017 Date accepted: 15 January 2018

\begin{abstract}
Granitoid plutons are a major component of pre-Carboniferous rocks in Cape Breton Island and knowledge of the time and tectonic setting of their emplacement is crucial for understanding the geological history of the island, guiding exploration for granite-related economic mineralization, and making alongorogen correlations. The distribution of these plutons and their petrological characteristics have been used in the past for recognizing both Laurentian and peri-Gondwanan components in Cape Breton Island, and for subdividing the peri-Gondwanan components into Ganderian and Avalonian terranes. However, ages of many plutons were assumed on the basis of field relations and petrological features compared to those of the relatively few reliably dated plutons. Seventeen new $\mathrm{U}-\mathrm{Pb}$ (zircon) ages from igneous units reported here provide enhanced understanding of the distribution of pluton ages. Arc-related plutons in the Aspy terrane with ages of ca. 490 to $475 \mathrm{Ma}$ likely record the Penobscottian tectonomagmatic event recognized in the Exploits subzone of central Newfoundland and New Brunswick but not previously recognized in Cape Breton Island. Arc-related Devonian plutonic activity in the same terrane is more widespread, continuous, and protracted (445 Ma to $395 \mathrm{Ma}$ ) than previously known. Late Devonian magmatism in the Ganderian Aspy terrane is similar in age to that in the Avalonian Mira terrane (380 to $360 \mathrm{Ma}$ ) but the tectonic settings are different. In contrast, magmatic activity in the Bras d'Or terrane is almost exclusively arc-related in the Late Ediacaran (580 to $540 \mathrm{Ma}$ ) and rift-related in the Late Cambrian (520 to $490 \mathrm{Ma}$ ). The new data support the terrane distinctions previously documented.
\end{abstract}

\section{RÉSUMÉ}

Les plutons granitoïdes sont des composants importants des roches précarbonifères de l'île du Cap Breton, et il est crucial de connaître le moment et le cadre tectonique de leur mise en place pour comprendre lévolution géologique de lîle, orienter l'exploration de la minéralisation économique liée au granite et établir des corrélations le long de lorogène. La distribution des plutons et leurs caractéristiques pétrologiques ont été utilisées dans le passé pour reconnaître les composants laurentiens et périgondwaniens dans l'île du Cap Breton et pour subdiviser les composants périgondwaniens entre les terranes gandériens et les terranes avaloniens. Cependant, lâge de bon nombre de plutons a été présumé en fonction des observations sur le terrain et de leurs caractéristiques pétrologiques comparativement à celles des plutons datés de manière fiable, relativement peu nombreux. Dix sept nouveaux âges $\mathrm{U}-\mathrm{Pb}$ sur zircon fondés sur des unités ignées et déclarés dans le présent document permettent de mieux comprendre la répartition selon lâge des plutons. Dans le terrane d'Aspy, des plutons liés à l'arc dont les âges se situent environ entre 490 et 475 Ma illustrent vraisemblablement l'événement tectonomagmatique penobscottien reconnu dans la sous-zone de la rivière Exploits dans le centre de Terre Neuve, mais qui n’a pas été reconnu auparavant à l'île du Cap-Breton. Lactivité plutonique Dévonien liée à l'arc dans le même terrane est plus répandue, continue et prolongée (445 Ma à $395 \mathrm{Ma}$ ) qu’on ne le croyait antérieurement. Le magmatisme du Dévonien tardif dans le terrane gandérien d'Aspy est d'un âge semblable à celui du terrane de Mira de l'Avalonien (380 Ma à $360 \mathrm{Ma}$ ); toutefois, les milieux tectoniques sont différents. En revanche, l'activité magmatique dans le terrane de Bras d'Or est quasi exclusivement liée à l'arc dans l'Édiacarien tardif (580 Ma à $540 \mathrm{Ma}$ ) et liée au 
rift dans le Cambrien tardif (520 Ma à $490 \mathrm{Ma}$ ). Les nouvelles données appuient les distinctions documentées antérieurement au sujet des terranes.

\section{[Traduit par la redaction]}

\section{INTRODUCTION}

Cape Breton Island, Nova Scotia, is a granite-lover's paradise. Granitoid plutons constitute more than half of preCarboniferous rocks on the island and more than 120 different plutons, many of them composite, have been named, ranging in age from Mesoproterozoic to Late Devonian (Barr and White 2017a). They formed in a variety of tectonic settings, are compositionally varied, and display diversity in isotopic characteristics (e.g., Barr 1990, 2010; Barr and Hegner 1992; Potter et al. 2008a, b). This granitoid diversity reflects the complex geology and geological evolution of the island. Cape Breton Island is made up of four lithotectonic divisions named (from north to south) the Blair River Inlier and Aspy, Bras d'Or, and Mira terranes (Fig. 1). The Blair River Inlier is interpreted to be of Laurentian affinity whereas the three terranes are of Gondwanan origin (Fig. 1, inset; Hibbard et al. 2006, 2007). The terranes, in themselves composite, were juxtaposed with the Blair River Inlier by the late Devonian because Carboniferous clastic and carbonate rocks correlate across the island (Fig. 1), although faulting (including strike-slip faults, thrust faults, and extensional detachment faults) continued during the Late Paleozoic and likely even into the Mesozoic (Waldron et al. 2015).

Until the mid-1970s, the granites of Cape Breton Island were assumed to be mainly Devonian, like those in southern Nova Scotia (e.g., Geological map of Nova Scotia 1965). The pioneering $\mathrm{Rb}-\mathrm{Sr}$ dating by Cormier (1972) gave strong evidence that such was not the case, although $\mathrm{U}-\mathrm{Pb}$ dating was required (beginning in the late 1980s) to establish a clear pattern, and petrological characteristics alone gave strong hints (e.g., Barr et al. 1982). Williams (1978) included all of Cape Breton Island in his Avalon Zone because his classic map was made before much was known about the geology of the island. Geological mapping, petrological studies, and geochronology subsequently revealed the geological complexity (Barr and Raeside 1989). It is now widely recognized that Cape Breton Island preserves a compressed cross-section of the Appalachian orogen from Avalonia in the southeast to Laurentian (Grenvillian) basement in the northwest (Hibbard et al. 2006), a fortunate circumstance that has been attributed to promontorypromontory collision between elements of Laurentia and Gondwana (Lin et al. 1994).

Differences in age and petrological character of granitoid rocks played a major role in the initial recognition of terranes in Cape Breton Island (e.g., Barr and Raeside 1989; Barr 1990). In some cases (Blair River Inlier vs. Aspy terrane) the differences are glaring; in other cases (Bras d'Or and Mira terranes) the contrast are subtle, with overlaps and similarities in ages and tectonic settings (e.g., Barr and White 1996). Although much progress has been made in knowledge of the ages of granitoid plutons in Cape Breton Island, ages of many plutons have been inferred based on apparent petrological similarity to dated plutons. Hence, geological interpretations continue to be hampered by lack of reliable dates.

The purpose of this paper is to present 17 new $\mathrm{U}-\mathrm{Pb}$ LA-ICPMS (zircon) ages mainly from plutonic units in the Aspy, Bras d'Or, and Mira terranes (Fig. 2) and discuss how they affect our understanding of the geological history of Cape Breton Island and its place in the northern Appalachian orogen. This paper provides an update on the publications by Lin et al. (2007) and Slaman et al. (2017), White et al. (2016), and Willner et al. (2013), the most recent compilations and interpretations of dates in northern, central, and southern Cape Breton Island, respectively.

\section{METHODS}

With one exception, the samples for this study were sent to Overburden Drilling Management (ODM) in Ottawa, Ontario, for electro-pulse disaggregation and initial zircon separation. Zircon grains for dating were then picked from the zircon concentrates at Cape Breton University. Selected grains were mounted in an epoxy-covered thin section at the University of New Brunswick, Fredericton, polished to expose the centres of the zircon grains, and imaged using cold cathodoluminescence to identify internal zoning and inclusions. These images were used to select ablation points (30 $\mu \mathrm{m}$ diameter), avoiding any visible inclusions, cracks, or other imperfections. In the exceptional sample, $11 \mathrm{~F} 16 \mathrm{c}-1115$, zircon grains were dated in situ in a polished thin section following methods described in Archibald et al. (2013).

$\mathrm{U}$ and $\mathrm{Pb}$ isotopic compositions were measured using the Resonetics S-155-LR $193 \mathrm{~nm}$ Excimer laser ablation system connected to an Agilent $7700 \times$ quadrupole inductively coupled plasma - mass spectrometer in the Department of Earth Sciences at the University of New Brunswick, following the procedure outlined by McFarlane and Luo (2012) and Archibald et al. (2013). Data reduction was done in-house using Iolite software (Paton et al. 2011) to process the laser output into data files, and further reduced for $\mathrm{U}-\mathrm{Pb}$ geochronology using VizualAge (Petrus and Kamber 2012). VizualAge outputs included uncorrected $\mathrm{U}-\mathrm{Pb}$ ratios that were used to calculate ${ }^{204} \mathrm{~Pb}$-based corrections (Anderson 2002) and ${ }^{208} \mathrm{~Pb}$-based corrections. Data were filtered using ${ }^{204} \mathrm{~Pb}$ as a monitor 


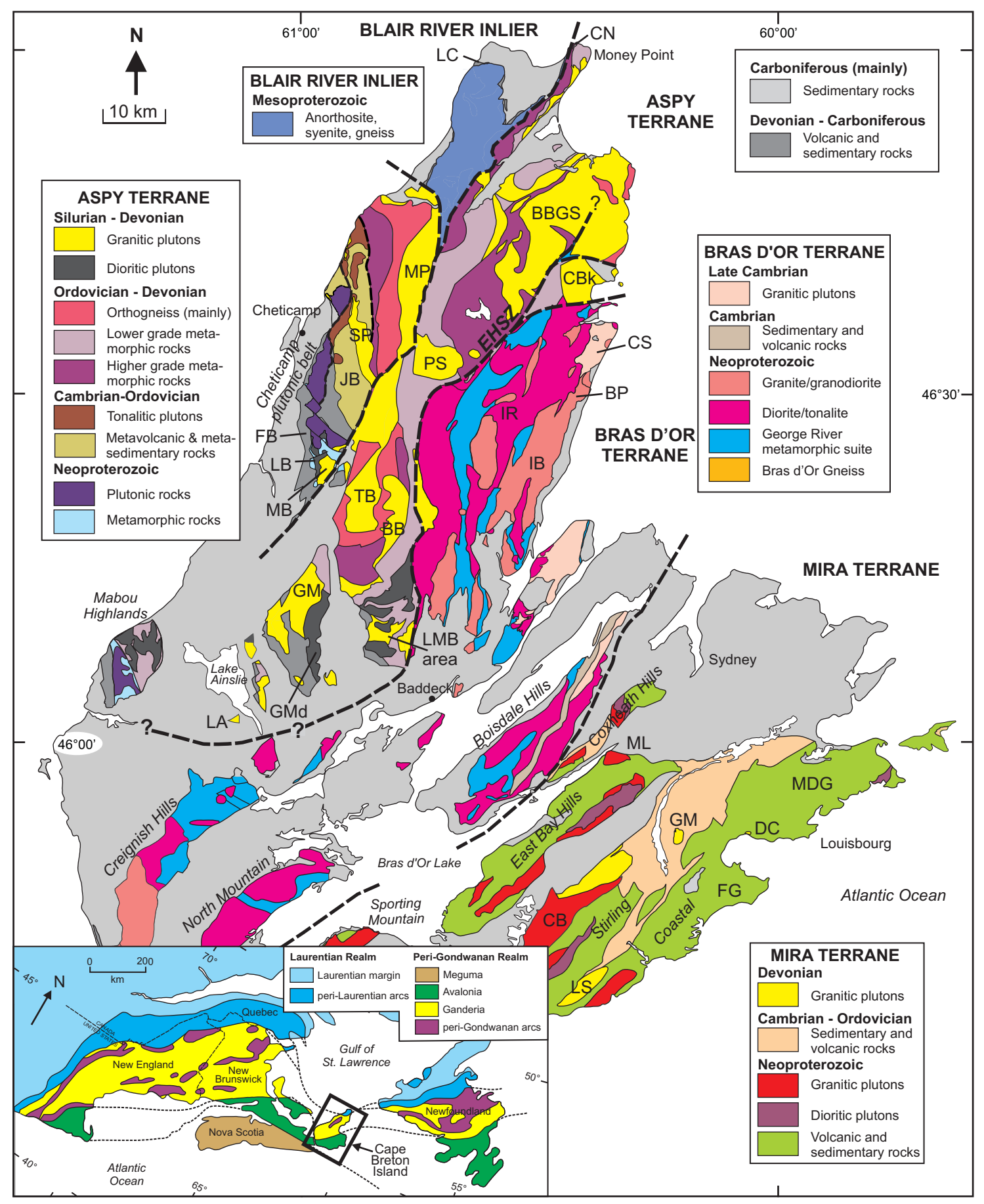

Figure 1. Simplified geological map of Cape Breton Island showing major geological components of the Blair River Inlier and Aspy, Bras d'Or, and Mira terranes. Areas and units referred to in the text are labelled. Abbreviations: BB, Bothan Brook pluton; BBGS, Black Brook Granitic Suite; BP, Birch Plain pluton; CB, Chisholm Brook plutonic suite; CBk, Cameron Brook pluton; CN, Cape North pluton; CS, Cape Smoky pluton; DC, Deep Cove pluton; EHSZ. Eastern Highlands Shear Zone; FB, Fisset Brook Formation; GF, Gisborne Flowage quartz diorite; FG, Fourchu Group; GM, Gillanders Mountain pluton; GMd, Gillanders Mountain diorite; GI, Gillis Mountain pluton; IB, Indian Brook granodiorite; IR, Ingonish River tonalite; JB, Jumping Brook metamorphic suite; LA, Lake Ainslie pluton; LB, Lavis Brook pluton; LC, Lowland Cove rhyolite; LMB, Leonard MacLeod Brook; LS, Lower St. Esprit pluton; MB, MacLean Brook pluton; MDG, Maina-Dieu Group; ML, MacEachern Lake pluton; MP, Margaree pluton; SP, Salmon Pool pluton; SR, Salmon River pluton; TB, Taylors Barren pluton. Inset map shows divisions of the northern Appalachian orogen after Hibbard et al. (2006). 


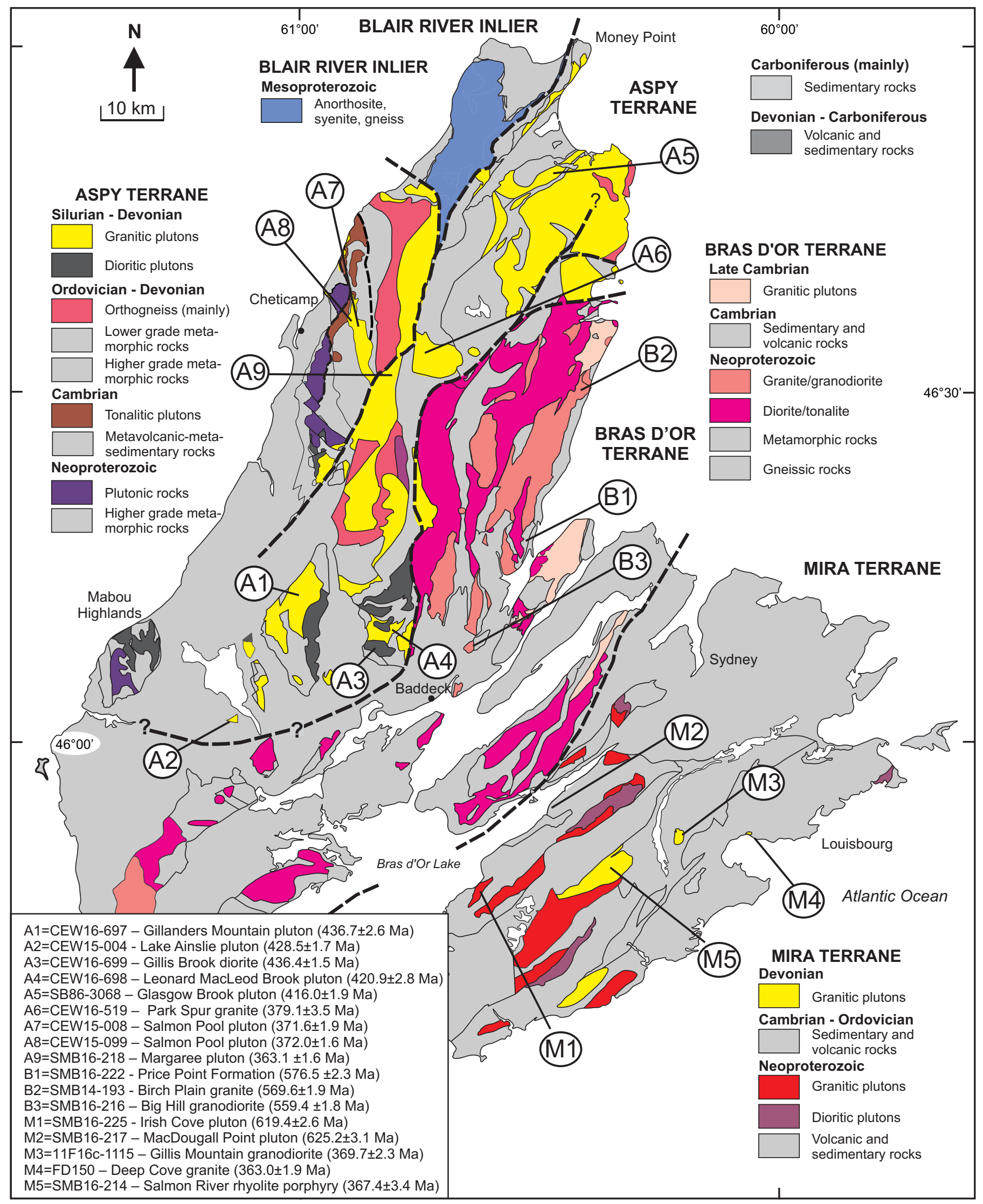

Figure 2. Simplified geological map of Cape Breton Island showing only plutonic units in colour and locations of samples for which ages are reported in this paper. Other units in grey are the same as in Figure 1. Samples are numbered by terrane (A series 1 to 9 for Aspy terrane samples, B series 1 to 3 for Bras d'Or terrane, and M series 1 to 5 for Mira terrane samples). 
For grains with $<80$ counts/s ${ }^{204} \mathrm{~Pb}$, data are uncorrected; for grains where the percentage error on the ${ }^{204} \mathrm{~Pb}$ counts per second was $<20 \%$, we used a ${ }^{204} \mathrm{~Pb}$-based correction (Andersen 2002), and for grains where the percentage of radiogenic $\mathrm{Pb}\left(\mathrm{PB}^{*}\right.$ in file) is less than $98.5 \%$ we used a ${ }^{208} \mathrm{~Pb}$-based correction (Petrus and Kam-ber 2012). After these corrections were applied, data were sorted by concordance $\left({ }^{206} \mathrm{~Pb} /{ }^{238} \mathrm{U}\right.$ versus $\left.{ }^{207} \mathrm{~Pb} /{ }^{235} \mathrm{U}\right)$, and by the percentage of radiogenic $\mathrm{Pb}$ in the grains as calculated using VizualAge. All analytical data are presented in Appendix A and B.

Concordia ages were calculated for clusters of three or more near-concordant points using Isoplot versions 3.75 and 4.15 (Ludwig 2003, 2012), and as many grains as possible that fit the criteria for inclusion in concordia calculations. All ages are reported at $95 \%$ confidence, with decayconstant errors included in the calculations. Data points included in the concordia calculations and reported here are grains that are $98 \%$ to $101 \%$ concordant and do not require a correction for common $\mathrm{Pb}\left({ }^{204} \mathrm{~Pb}<80\right.$ counts per second). The approach in this study was to calculate concordia ages using as many grains as possible, and hence the MSWD (mean square of weighted deviates) which measures the amount of scatter in the points used to calculate concordia and the reported probability of concordance could in some cases be improved by using fewer grains. In all cases the calculated concordia ages overlap with the weighted mean ages for the samples using all near-concordant data. ${ }^{206} \mathrm{~Pb} /{ }^{238} \mathrm{U}$ ages are used in all the probability distribution calculations.

Concordia ages for standard 91500 were $1051.0 \pm 8.1 \mathrm{Ma}$ and $1048.1 \pm 4.8 \mathrm{Ma}$ in two runs, $413.5 \pm 3.3 \mathrm{Ma}$ for the Temora standard in one run, and 694.4 $\pm 4.2 \mathrm{Ma}$ for Tanzania standard in one run. Concordia ages for standard $\mathrm{FC} 1$ were $1099.0 \pm 3.2 \mathrm{Ma}, 1099.1 \pm 3.4 \mathrm{Ma}, 1099.1 \pm 3.2 \mathrm{Ma}, 1098.1 \pm$ $3.4 \mathrm{Ma}, 1099.1 \pm 2.7 \mathrm{Ma}, 1098.8 \pm 2.5 \mathrm{Ma}, 1098.9 \pm 2.1 \mathrm{Ma}$, $1098.9 \pm 2.8 \mathrm{Ma}, 1098.6 \pm 3.7 \mathrm{Ma}, 1098.7 \pm 3.0 \mathrm{Ma}, 1098.9$ $\pm 2.9 \mathrm{Ma}$, and $1099.1 \pm 4.7 \mathrm{Ma}$ during twelve separate runs. Concordia ages for standard Plesovice were $336.9 \pm 2.3 \mathrm{Ma}$, $337.1 \pm 2.1 \mathrm{Ma}, 337.0 \pm 2.1 \mathrm{Ma}, 335.7 \pm 2.0 \mathrm{Ma}, 337.9 \pm 1.6$ $\mathrm{Ma}, 336.1 \pm 2.0 \mathrm{Ma}, 337.03 \pm 0.94 \mathrm{Ma}, 337.0 \pm 1.5 \mathrm{Ma}, 339.5$ $\pm 1.9 \mathrm{Ma}, 339.5 \pm 1.5 \mathrm{Ma}, 339.0 \pm 1.4 \mathrm{Ma}$, and 333.5 $\pm 1.9 \mathrm{Ma}$ during twelve separate runs. NIST610 glass was used as a concentration standard. Standard data are presented in Appendix B.

\section{BLAIR RIVER INLIER}

Although no new ages were obtained from the Blair River Inlier in the present study, a short summary is included here for comparison with the adjacent Aspy terrane. The Blair River Inlier forms the northwestern part of Cape Breton Island (Fig. 2) and consists mainly of several composite orthogneissic units, intruded by less deformed plutons of varied compositions including anorthosite, gabbro, syenite, and granite. Miller et al. (1996) and Miller and Barr
(2000) reported $\mathrm{U}-\mathrm{Pb}$ ages confirming that major units in the inlier are Mesoproterozoic, including the Sailor Brook gneiss (>1217 Ma), Lowland Brook Syenite $(1080+5 /-3$ Ma), Red River Anorthosite Suite ( $>1095 \mathrm{Ma})$, and Otter Brook gneiss $(978+6 /-5 \mathrm{Ma})$. They also showed that highgrade metamorphism of the Sailor Brook gneiss occurred at $1035+12 /-10 \mathrm{Ma}$, and that the Red River Anorthosite Suite was metamorphosed at 996+6/-5 Ma. The Mesoproterozoic units of the Blair River Inlier are distinct in both age and composition from rocks in other parts of Cape Breton Island and in northern Appalachian outboard terranes in general. They contain rock types and ages similar to those typical of the Grenville Province of Laurentia and similar to those in other Grenvillian basement inliers in the Appalachian orogen, such as the Steel Mountain, Indian Head, and Long Range inliers in western Newfoundland (e.g., Heaman et al. 2002). Thus, the Blair River Inlier is interpreted to be an exposure of Laurentian Grenvillian basement that was deformed, metamorphosed, and intruded by granite during Appalachian orogenic events (Miller et al. 1996; Barr et al. 1995, 1998).

Minor Paleozoic igneous activity in the Blair River Inlier is indicated by the presence of a small granite pluton with an age of $435+7 /-3 \mathrm{Ma}$ (Miller et al. 1996). In addition, Paleozoic amphibolite-facies metamorphism is reflected in ca. $425 \mathrm{Ma}$ titanite ages from the Proterozoic units, and subsequent cooling through hornblende, muscovite, and phlogopite $\left({ }^{40} \mathrm{Ar} /{ }^{39} \mathrm{Ar}\right)$ and rutile $(\mathrm{U}-\mathrm{Pb})$ closure temperatures continued until ca. $410 \mathrm{Ma}$ (Barr et al. 1995; Miller et al. 1996). A later, probably Devonian, greenschist-facies overprint is most intense near chlorite-grade shear zones and brittle fault zones. The inlier is fringed by Late Devonian volcanic and sedimentary rocks of the Lowland Cove Formation, rhyolite from which has yielded a $\mathrm{U}-\mathrm{Pb}$ (zircon) age of $365 \pm 2 \mathrm{Ma}$ (Dunning et al. 2002). Mylonitic fault zones separate the Blair River Inlier from the adjacent Aspy terrane (Raeside and Barr 1992).

\section{ASPY TERRANE}

\section{Geological setting}

The Aspy terrane contains widespread low- to high-grade metavolcanic and metasedimentary rocks and large areas of orthogneiss and less abundant paragneiss, all metamorphosed in the late Silurian to early Devonian (ca. 420-400 Ma) (Dunning et al. 1990; Reynolds et al. 1989; Barr et al. 1998; Horne et al. 2003; Lin et al. 2007). Older plutonic and metamorphic rocks with ages of ca. 620,567, and 480-490 Ma occur in the western part of the terrane (Lin et al. 2007; Slaman et al. 2017). These older rocks have difficult-todemonstrate relationships with the younger mid-Paleozoic metamorphic rocks (and associated plutons) that dominate in the rest of the terrane, but are likely to constitute their basement. The younger metamorphic rocks include metavolcanic, metasedimentary, and gneissic rocks of Or- 
dovician and Silurian (ca. 450-430 Ma) age. They were involved in high-pressure amphibolite-facies metamorphism in the late Silurian - early Devonian (Plint and Jamieson 1989; Reynolds et al. 1989; Price et al. 1999). The protolith ages for these metamorphic rocks are somewhat uncertain, but they appear to include both Neoproterozoic and Ordovician-Silurian components (Lin et al. 2007; Slaman et al. 2017). They have been subdivided into map units that are separated by plutons, faults, and/or Carboniferous rocks and assigned local names because of the difficulty of making correlations throughout the area (e.g., Barr and Jamieson 1991; Lin et al. 2007). Lin (1993) and Chen et al. (1995) reported detrital zircon ages from metaconglomerate in the eastern part of the Aspy terrane and suggested that the presence of grains with ages of ca. $495 \mathrm{Ma}$ suggests an original depositional link with the Bras d'Or terrane which contains plutons of late Cambrian to early Ordovician age (Barr et al. 1990; Dunning et al. 1990).

The metamorphic rocks in the Aspy terrane have been intruded by abundant plutons with ages based on earlier work of ca. $440 \mathrm{Ma}, 430 \mathrm{Ma}, 400 \mathrm{Ma}$, and 375-365 Ma (Dunning et al.1990; Barr et al.1990; Horne et al. 2003). Such plutons are mainly absent from the Bras d'Or terrane, although the location of the boundary is uncertain in its eastern part, where the Eastern Highlands Shear Zone is inferred to branch; one branch appears to be stitched by the ca. 375 Ma Black Brook Granitic Suite (Yaowanoiyothin and Barr 1991) but branches to the south split around the mid-Devonian Cameron Brook pluton (Fig. 1).

In simplistic terms, Aspy terrane plutons include all of Itype, S-type, and A-type (Barr 1990). The oldest plutons are orthogneissic and foliated dioritic, tonalitic, and granitic plutons with ages of ca. 440 to $425 \mathrm{Ma}$ and petrological features consistent with formation in a subduction zone setting. Together with volcanic rocks of similar ages, they are inferred to have formed in a volcanic-arc setting offshore from the Bras d'Or terrane and on Bras d'Or terrane crust (e.g., Barr et al. 1996a; Price et al. 1999). Younger ca. 400 Ma plutons such as Cameron Brook mainly occur within branches of the Eastern Highlands Shear Zone (Fig. 2) and may have formed in conjunction with early stages of juxtaposition with the Bras d'Or terrane. They also have volcanic-arc characteristics (Barr 1990). In contrast, the Black Brook Granitic Suite with an age of ca. 375 Ma has S-type characteristics and likely formed in a syn-collisional setting (Yaowanoiyothin and Barr 1991). At a similar time but elsewhere in the Aspy terrane, large A-type plutons were emplaced, apparently related to extension and the opening of rift basins in which bimodal volcanic rocks were formed, as well as nonmarine sedimentary successions (e.g., Dunning et al. 2002). The bimodal volcanic rocks have within-plate characteristics (e.g., Barr et al. 1995; Barr and Peterson 1998), as do the related granitic plutons which include the megacrystic Margaree pluton with its distinctive Rapakivi texture (O’Beirne-Ryan et al. 1986).

\section{New ages from the Aspy terrane (Appendix A)}

\author{
A1. Sample CEW16-697 - Gillanders Mountain pluton \\ $(436.7 \pm 2.6 \mathrm{Ma})$
}

Sample CEW16-697 is medium-grained biotite monzogranite from the Gillanders Mountain pluton. This rock unit previously yielded a Devonian Rb-Sr age (French 1985). The dated sample consists of approximately equal amounts of plagioclase, microcline, and quartz, and less than $10 \%$ biotite. As is typical of the pluton (French 1985), the quartz is interstitial and recrystallized into a mosaic of small anhedral grains. The zircon grains in this sample are mostly elongate euhedral crystals and bipyramidal terminations and a 3:1 to 5:1 aspect ratio. The grains are typically cloudy and stained brown. Ten grains yield a calculated concordia age of $436.7 \pm 2.6 \mathrm{Ma}$, interpreted as the main age of crystallization with an MSWD of 0.46 , and probability of concordance of 0.50 (Fig. 3a). Younger ages from 6 grains do not make an overlapping cluster, and are interpreted as resulting from $\mathrm{Pb}$ loss.

The age of $436.7 \pm 2.6 \mathrm{Ma}$ is similar to early Silurian ages reported by Slaman et al. (2017) for the MacLean Brook and Lavis Brook plutons in the Cheticamp plutonic belt to the north (Figs. 1, 2), and confirms that Silurian plutonic rocks are widespread in Aspy terrane. It is somewhat older than the previously dated Silurian Gillanders Moun-tain diorite (428.6 $\pm 1.9 \mathrm{Ma}$; Lin et al. 2007), and is significantly older than rhyolite of the adjacent Fisset Brook Formation dated at $373 \pm 4$ Ma by Dunning et al. (2002).

A2. Sample CEW15-004 - Lake Ainslie pluton (428.5 $\pm 1.7 \mathrm{Ma}$; older grains at $440.3 \pm 1.9 \mathrm{Ma}$ )

Granite occurs in a small area southwest of Lake Ainslie (French 1985). Outcrop is limited but logging roads have provided new outcrops which confirm the presence of both monzogranite and flow-banded rhyolite (C. White, unpublished data, 2015). The dated sample is medium-grained pink biotite-hornblende monzogranite with a distinctive texture of subhedral plagioclase, biotite, and less abundant amphibole with interstitial orthoclase and quartz. This sample contains abundant clear, euhedral zircons from 20 to $150 \mu \mathrm{m}$. Most of the grains are rectangular with bipyramidal terminations but some are more rounded. Most are inclusion free. In CL the grains show oscillatory zoning.

The probability distribution for this sample shows a large peak of ages between 425 and $430 \mathrm{Ma}$, and a secondary peak between 435 and $445 \mathrm{Ma}$ (Fig. 3b). The younger peak has a calculated concordia age of $428.5 \pm 1.7 \mathrm{Ma}$ with an MSWD of 0.83 , and a probability of concordance of 0.36 using 11 grains in the calculation (Fig. 3c). The older population has a calculated concordia age of $440.3 \pm 1.9 \mathrm{Ma}$ with an MSWD of 2.8, and a probability of concordance of 0.093 using 5 grains in the calculation (Fig. 3d). We interpret the younger age of $428.5 \pm 1.7 \mathrm{Ma}$ as the main age of crystallization of the monzogranite, and the older age of $440.3 \pm 1.9 \mathrm{Ma}$ as representing inherited or anacrystic grains. 

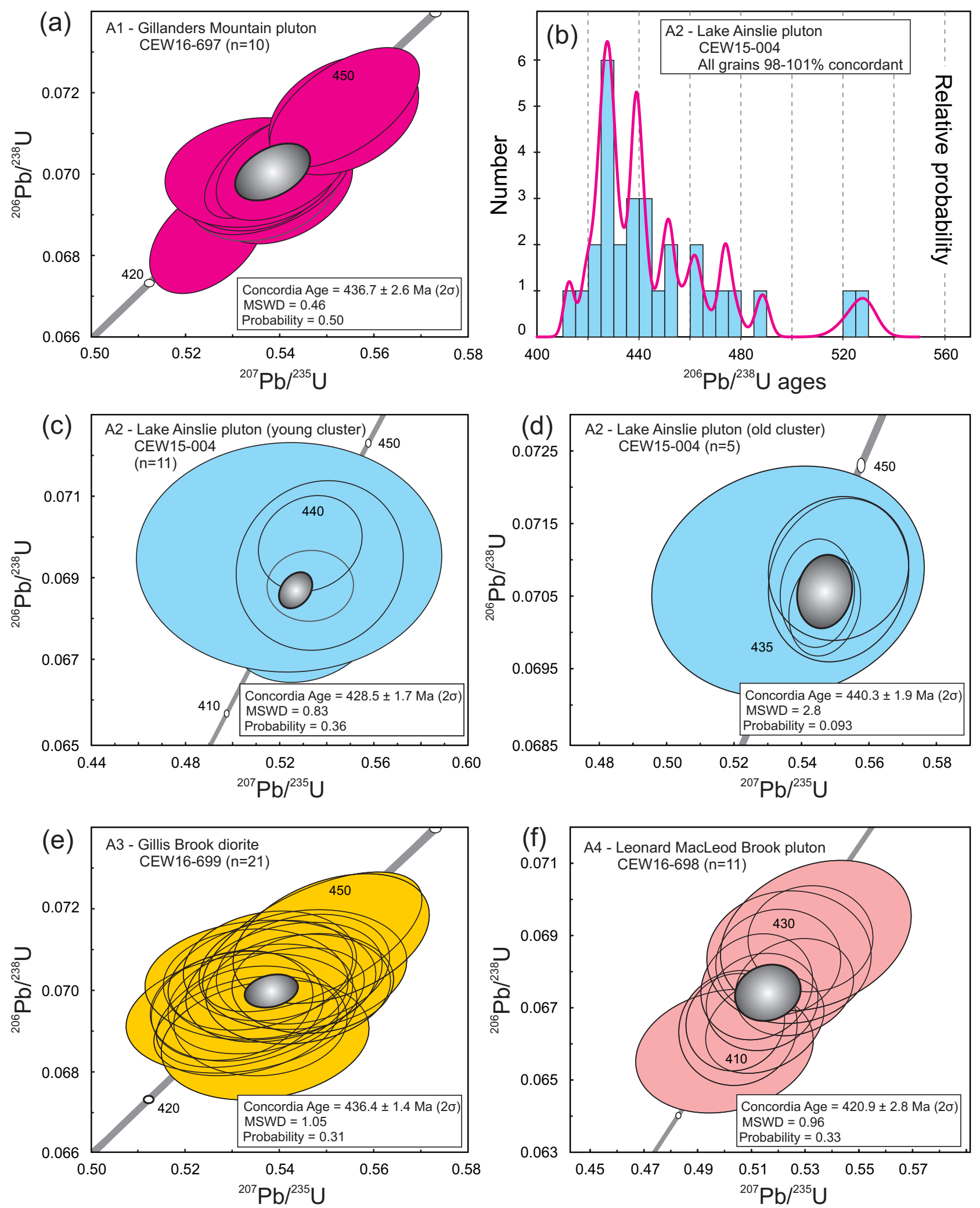

Figure 3. Concordia diagrams and probability plots for plutons in the Aspy terrane: (a) concordia diagram for zircon from monzogranite of the Gillanders Mountain pluton; (b) probability plot and histogram for monzogranite of the Lake Ainslie pluton; (c) concordia diagram showing the youngest 11 concordant and near-concordant zircon grains from monzogranite of the Lake Ainslie pluton; (d) concordia diagram showing 5 older concordant and near-concordant zircon grains from monzogranite of the Lake Ainslie pluton; (e) concordia diagram for zircon grains from the Gillis Brook diorite; (f) concordia diagram for monzogranite of the Leonard MacLeod Brook pluton. 
The similarity of the younger crystallization age to that of the Gillanders Mountain diorite (428.6 $\pm 1.9 \mathrm{Ma}$; Lin et al. 2007) and Taylors Barren pluton ( $430 \pm 2 \mathrm{Ma}$; Horne et al. 2003) and the older age to that of the Gillanders Mountain monzogranite (A1; Fig. 3a) supports the interpretation that this small area of granite and rhyolite is indeed part of the Aspy terrane, and hence lies north of the boundary with Bras d'Or terrane (Fig. 2). The position of the terrane boundary is otherwise poorly constrained in this area due to Carboniferous cover rocks.

As shown in the probability distribution (Fig. 3b), sample CEW15-004 also contains even older inherited grains in the 460 to $480 \mathrm{Ma}$ range and 520 to $530 \mathrm{Ma}$ range. These ages are all represented by igneous events documented elsewhere in the Aspy terrane (e.g., Slaman et al. 2017).

\section{A3. Sample CEW16-699 - Gillis Brook diorite (436.1 $\pm 1.4 \mathrm{Ma})$}

The Gillis Brook diorite was mapped by O'Neill (1996) as a separate component within the area of the Leonard MacLeod Brook complex of Barr et al. (1992). He described the unit to consist of fine- to medium-grained dioritic rocks. The dated sample is from the southern part of the unit and is more gabbroic than dioritic. It consists of medium-grained plagioclase and relict clinopyroxene with abundant secondary minerals including biotite, chlorite, epidote, iron oxides/hydroxides, sericite, and carbonate minerals.

Zircons in this sample are transparent, inclusion-free, and tabular, with rounded edges. Some are subhedral and have clear facets. Some grains show brownish-red surface staining. In CL most grains show oscillatory zoning. Twenty-one grains yielded a calculated concordia age of $436.1 \pm 1.4 \mathrm{Ma}$, interpreted as the main age of crystallization (Fig. 3e), with MSWD of 1.05, and a probability of concordance of 0.31. The age of $436.1 \pm 1.4$ Ma shows that the diorite is Silurian, similar in age to the Lavis Brook diorite and MacLean Brook granite in the Cheticamp belt reported by Slaman et al. (2017) and somewhat older than the nearby diorite at Gillanders Mountain $(428.6 \pm 1.9$ Ma; Lin et al. 2007). However, it is similar to the age of Gillanders Mountain monzogranite sample CEW16-697 (436.7 \pm 2.6 Ma; A1, Fig. 3a). It is older than the Leonard MacLeod Brook monzogranite with which it is closely associated (see A4 below), and 70 million years older than the nearby Bothan Brook pluton dated at $376 \pm 3 \mathrm{Ma}$ (Horne et al. 2003).

\section{A4. Sample CEW16-698 - Leonard MacLeod Brook monzoganite $(420.9 \pm 2.8 \mathrm{Ma})$}

Several types of granite occur in the enigmatic Leonard MacLeod Brook complex of Barr et al. (1992). O'Neill (1996) mapped and named the component plutons, as well as recognizing volcanic rocks which he assumed to be Silurian. Dated sample CEW16-698 is a fine-grained monzogranite from the Leonard MacLeod Brook plutonic suite of O'Neill (1996), which he inferred to be Devonian, like the associated Bothan Brook pluton which has an age of $376 \pm 3$
Ma (Horne et al. 2003). The sample consists of a fine- to medium-grained mosaic of recrystallized K-feldspar and plagioclase; quartz is much less abundant than feldspar and is fine-grained and recrystallized in the interstices. Flakes of green biotite are also present, as well as scattered phenocrysts of plagioclase.

Zircon grains in this sample are all small, between 30 and $50 \mu \mathrm{m}$, and are short and stubby with euhedral shapes. About half are transparent and colourless and half are cloudy with inclusions. The larger grains show oscillatory zoning in CL but the smaller ones do not have distinct zones. Eleven grains yield a calculated concordia age of $420.9 \pm 2.8 \mathrm{Ma}$ (Fig. 3f) interpreted as the main age of crystallization (Fig. 3f) with an MSWD of 0.96 , and a probability of concordance of 0.33 .

This age shows that the granite is Silurian, but younger than both the associated Gillis Brook diorite (436.1 \pm 1.4 Ma; Fig. 3e) and the nearby diorite at Gillanders Mountain (428.6 $\pm 1.9 \mathrm{Ma}$; Lin et al. 2007), as well as monzogranite samples CEW16-697 (436.7 \pm 2.6 Ma; Fig. 3a) and CEW15004 (428.5 \pm 1.7 Ma; Fig. 3c) from the Gillanders Mountain and Lake Ainslie plutons, respectively. The Leonard MacLeod Brook granite is also younger than the Taylors Barren pluton to the north which has an age of $430 \pm 2 \mathrm{Ma}$ (Horne et al. 2003). Thus, Silurian plutonism in this part of the Aspy terrane appears to be both more widespread and more protracted than previously recognized.

A5. Sample SB86-3068 - Glasgow Brook pluton (416.0 $\pm 1.9 \mathrm{Ma}$ )

The Glasgow Brook pluton is an elongate intrusion located near the northwestern margin of the Devonian Black Brook Granitic Suite. The extent of the pluton as defined by Wiebe (1975) was essentially confirmed by Raeside and Barr (1992). On its northern margin the pluton intruded schist of the Money Point Group, in which it occurs as sheets adjacent to contacts. A narrow band of mica schist separates the pluton from the Black Brook Granitic Suite. Dioritic and semipelitic xenoliths are locally abundant in the pluton, which consists of strongly foliated medium- to coarse-grained hornblende-biotite tonalite to granodiorite. The rock is gneissic in appearance, with mafic minerals concentrated on foliation planes, separated by quartzofeldspathic layers with augen of feldspar and quartz. The relative proportions of hornblende and biotite vary from dominantly hornblende to exclusively biotite. More biotite-rich rocks contain abundant myrmekite. Feldspars are oligoclase-andesine and microcline. Apatite, titanite, and zircon are variably abundant accessory minerals, together with minor opaque minerals. Garnet is rarely present. Epidote is an abundant secondary mineral. The dated sample is tonalitic, with only minor K-feldspar and amphibole.

This sample contained abundant zircons, generally acicular to elongate and euhedral. Most of the grains are $<30$ $\mu \mathrm{m}$, but many are in the 50 to $100 \mu \mathrm{m}$ range. Most of the grains are transparent and inclusion free but some are more yellow. In CL the grains show clear oscillatory zoning and 
bright fluorescence. The sample has a calculated concordia age of $416.0 \pm 1.9 \mathrm{Ma}$ with an MSWD of 8.0, and a probability of concordance of 0.005 when 13 grains are included in the calculation (Fig. 4a). The MSWD and probability of concordance could be improved by using fewer grains to calculate them, but as noted in the Methods section, our procedure is to calculate ages with as many near-concordant grains as possible. The probability distribution (Fig. 4b) for this sample shows two indistinct peaks with very little separation between them, both between 410 and 420 Ma. Because there is no clear separation between the peaks (with larger bin sizes the two peaks become one) we interpret the crystallization age of the sample to be the 416.0 $\pm 1.9 \mathrm{Ma}$ age presented above, which overlaps with the weighted mean age of all the 98 to $101 \%$ concordant grains at $412.4 \pm 3.9$ at $95 \%$ confidence level.

This early Devonian age is a new one for the Aspy terrane, except for a $\mathrm{U}-\mathrm{Pb}$ (zircon) age of $414 \pm 3$ interpreted to be the igneous crystallization age of a small granitic pluton in the Cape North Group near Money Point reported by Keppie et al. (1992).

\section{A6. Sample CEW16-519 - Park Spur granite (379.1 $\pm 3.5 \mathrm{Ma})$}

The Park Spur granite is located in the Aspy terrane close to the Eastern Highlands Shear Zone, the bound-ary between Aspy and Bras d'Or terranes. It is a fine- to medium-grained granite with both muscovite and biotite. It was previously undated but assumed to be mid-Devo-nian and related to the Black Brook Granitic Suite (Rae-side and Barr 1992). The dated sample is medium-grained monzogranite with minor $(<5 \%)$ muscovite and biotite. Quartz is polygranular and interstitial to feldspar, which includes both plagioclase and microcline.

The sample contains few zircon grains and every grain that could be picked was analysed. Grains vary in shape from euhedral to rounded. In CL the grains do not show bright fluorescence but zoning is visible in the larger grains. The calculated concordia age of $379.1 \pm 3.5 \mathrm{Ma}$ is interpreted as the main age of crystallization (Fig. 4c) with an MSWD of 0.084 , with a probability of concordance of 0.77 . In this case only three grains are in the concordia age calculation, but they overlap, and make a peak in the frequency distribution. No other clusters occur in the dataset, which includes very few concordant grains. The age of $379.1 \pm 3.5 \mathrm{Ma}$ confirms the inferred Late Devonian age based on petrographic similarities previously proposed (Raeside and Barr 1992), and is within error of the $\mathrm{U}-\mathrm{Pb}$ zircon ( $375+5 /-4 \mathrm{Ma})$ and monazite (372 to $373 \mathrm{Ma}$ ) ages from the Black Brook Granitic Suite (Dunning et al. 1990).

\section{A7. Sample CEW15-008 - Salmon Pool quartz monzonite $(371.6 \pm 1.7 \mathrm{Ma})$}

The Salmon Pool pluton consists of granite and gabbro; new mapping has shown that the pluton extends farther south than previously mapped and cross-cuts the Western Highlands (Pigeon Cove) shear zone (White et al. 2017). It has also shown that the gabbro and granite component can be mapped as separate units, although they are mingled in some outcrops. The pluton intruded the eastern margin of the Cambrian(?) Jumping Brook Metamorphic Suite. The Salmon Pool pluton has long been known to be Devonian based on an imprecise $\mathrm{U}-\mathrm{Pb}$ (zircon) age of $365+10 /-5 \mathrm{Ma}$ reported by Jamieson et al. (1986). The pluton is well exposed in Cheticamp River where two varieties of granite - quartz monzonite and monzogranite - are mingled with and/or contain xenoliths of varied mafic rocks, including gabbro, diorite, and amphibolite. Both the quartz monzonite and monzogranite were dated to check whether or not they are the same age.

Dated sample CEW15-008 is quartz monzonite with abundant amphibolitic xenoliths likely derived from the Faribault Brook Formation of the Jumping Brook Metamorphic Suite. The dated sample is medium-grained and consists of abundant subhedral plagioclase and less abundant interstitial K-feldspar. Interstitial quartz is less abundant than K-feldspar and forms less than $10 \%$ of the rock. Green amphibole and minor bioitite form about $10 \%$ of the rock, and accessory titanite is abundant.

This sample contains abundant zircons in the 50 to 120 $\mu \mathrm{m}$ size range. All grains are short, rectangular, and euhedral, and most have bipyramidal terminations. They are reddish to brown or cloudy with inclusions; only a few grains are transparent. In CL the grains fluoresced clearly showing oscillatory zoning in most grains, although some of the smaller grains are not zoned. The analyzed grains yielded a calculated concordia age of $371.6 \pm 1.7 \mathrm{Ma}$ with an MSWD of 3.7, and a probability of concordance of 0.053 with 12 grains included in the calculation (Fig. $4 \mathrm{~d}$ ).

These data provide a more precise age for the pluton than the date by Jamieson et al. (1986) which has large errors. The age is consistent with a comagmatic relationship of the pluton with the mafic and felsic volcanic rocks of the ca. 374 Ma Fisset Brook Formation (Barr and Peterson 1998).

\section{A8. Sample CEW15-099 - Salmon Pool monzogranite $(372.0 \pm 1.6 \mathrm{Ma})$}

A second sample from the Salmon Pool pluton was also dated to determine if the petrographically different felsic components of the pluton are of similar age. The dated sample consists of approximately equal amounts of quartz, $\mathrm{K}$-feldspar, and plagioclase, and is the most abundant rock type in the felsic part of the pluton. The ferromagnesian mineral is biotite which forms about $5 \%$ of the rock.

This sample contains abundant zircons in the 50 to 100 $\mu \mathrm{m}$ range, with more small grains than in the quartz monzonite sample CEW15-008. All grains are short, rectangular, and euhedral, and most have bipyramidal terminations. Most grains are reddish to brown or cloudy with inclusions, and clear grains were very few. In CL the grains fluoresce less well than the grains in CEW15-008, but still show oscillatory zoning in most grains except for smaller grains which are not clearly zoned. 

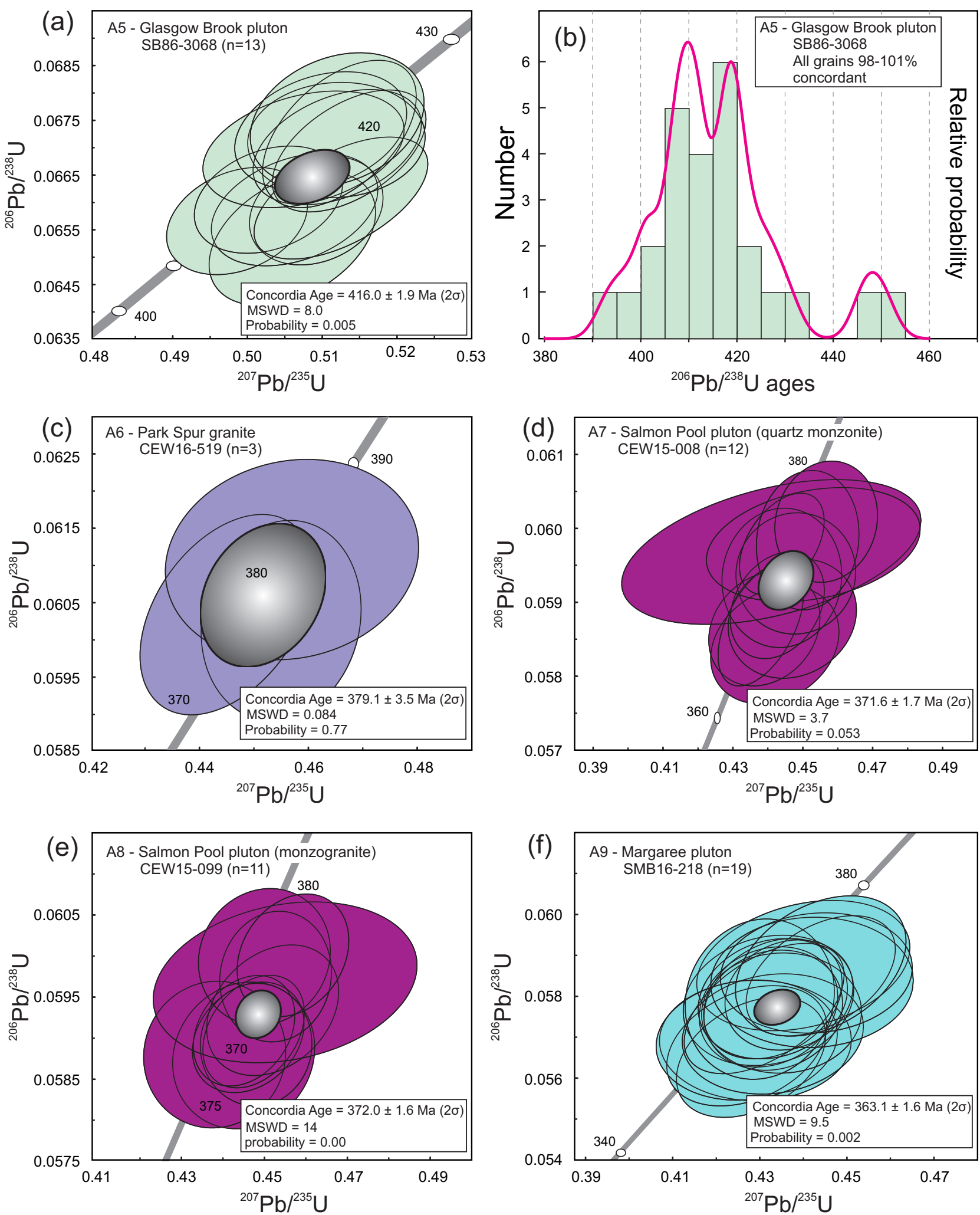

Figure 4. Concordia diagrams and probability plots for plutons in the Aspy terrane: (a) concordia diagram for zircon from tonalite of the Glasgow Brook pluton; (b) probability plot and histogram for zircon from tonalite of the Glasgow Brook pluton; (c) concordia diagram for the Park Spur granite; (d) concordia diagram for quartz monzonite sample CEW16-008 of the Salmon Pool pluton; (e) concordia diagram for granite sample CEW16-009 of the Salmon Pool pluton; (f) concordia diagram for megacrystic granite of the Margaree pluton. 
The sample has a calculated concordia age of $372.0 \pm$ 1.6 Ma with an MSWD of 14, and a probability of concordance of 0.000 when 11 grains are included in the calculation (Fig. 4e). The weighted mean age of all the 98 to $101 \%$ concordant grains is $372.5 \pm 3.2$ at $95 \%$ confidence level. Both these ages overlap with the calculated concordia age of the Salmon Pool quartz monzonite (CEW15-008) discussed previously and show that the two varieties are comagmatic.

\section{A9. Sample SMB16-218 - Margaree pluton (363.1 $\pm 1.6 \mathrm{Ma}$ )}

The Margaree pluton is the largest pluton in the Aspy terrane and consists mostly of distinctive megacrystic granite with plagioclase-rimmed K-feldspar (O'Beirne-Ryan et al. 1986). The pluton was previously dated by the $\mathrm{Rb}-\mathrm{Sr}$ method and yielded a date of $353 \pm 13 \mathrm{Ma}$ (O'Beirne-Ryan et al. 1986). It was assumed to be the same age as the ca. $375 \mathrm{Ma}$ rhyolite of the bimodal Fisset Brook Formation (Dunning et al. 2002) and the $365+10 /-5$ Ma granite of the Salmon Pool pluton (Jamieson et al. 1986), and like them related to post-orogenic extension (Barr and Jamieson 1991).

Sample SMB16-218 is syenogranite with megacrysts of Kfeldspar and smaller grains of quartz and plagioclase, typical of much of the pluton. Biotite forms 5\% of the rock, and allanite is an accessory component. Zircon crystals in this sample are generally elongate euhedral to subhedral grains. The finer zircon crystals in the sample $(<100 \mu \mathrm{m})$ are mostly euhedral, showing bipyramidal terminations. Most grains are transparent but some show orange and black staining. Nineteen grains yielded a calculated concordia age of 363.1 $\pm 1.6 \mathrm{Ma}$ interpreted as the main age of crystallization (Fig. 4f) with an MSWD of 9.5, and probability of concordance of 0.002. As mentioned in the methods, the MSWD and probability of concordance could be improved by using fewer grains to calculate them, but this age is calculated with as many near-concordant grains as possible.

This is the youngest igneous age yet reported in the Aspy terrane, and is especially significant because of the large size of the Margaree pluton. The pluton straddles the prominent Aspy Fault, and also appears to "stitch" the shear zones that separate the Grenville-age Blair River Inlier from the rest of the highlands. The new age is the same within error as the age of $365 \pm 2$ Ma reported by Dunning et al. (2002) from rhyolite in the Lowland Cove Formation in the Blair River Inlier. The new $\mathrm{U}-\mathrm{Pb}$ age is at the upper limit of the error range of an $\mathrm{Rb}-\mathrm{Sr}$ date of $353 \pm 13 \mathrm{Ma}$ (O'BeirneRyan et al. 1986). It is significantly younger than the Fisset Brook rhyolite. Hence the Late Devonian magmatic history of the Aspy terrane is more protracted than previously assumed; the young events recorded in both the Aspy terrane and Blair River Inlier suggest that those two areas were in proximity by that time.

\section{BRAS D'OR TERRANE}

\section{Geological setting}

In contrast to the Aspy terrane, the Bras d'Or terrane is dominated by Neoproterozoic and Cambrian rocks (Fig. 1). It contains fault-bounded blocks of Neoproterozoic low-pressure amphibolite-facies gneiss, much more extensive belts of greenschist-facies (and in places higher grade) quartzite, marble, meta-greywacke, and minor volcanic rocks, and abundant Ediacaran and Cambrian plutons (Raeside and Barr 1990; White et al. 1994, 2003, 2016). The relationship between the two suites of metamorphic rocks is uncertain but recent dating and petrological studies suggest that they are equivalent units at different metamorphic grades (White et al. 2016; van Rooyen et al. 2017).

Both low- and high-grade units are intruded by plutons with published ages mainly between ca. 560 and $553 \mathrm{Ma}$. They are subduction zone-related dioritic, tonalitic, granodioritic, and granitic plutons. Plutonic rocks are especially abundant in the eastern Cape Breton Highlands, where several of the plutons contain high-Al hornblende and magmatic epidote, indicative of crystallization at pressures of over $800 \mathrm{MPa}$ (25 km depth) (Farrow and Barr 1992). These rocks are interpreted to represent the deep levels of an Andean-type continental margin subduction zone, whereas plutons and in places volcanic rocks assumed to be co-magmatic in the southern part of the terrane represent higher level parts of the same subduction zone igneous assemblage. Post-orogenic late Cambrian granitic plutons are also present, and middle Cambrian to Early Ordovician volcanic and sedimentary rocks are preserved in a downfaulted block in the Boisdale Peninsula. Although similar to the Cambrian sequence on Mira terrane, the Cambrian rocks in the Boisdale Peninsula are firmly linked to $\mathrm{B}$ ras d'Or terrane and hence to Ganderia. Similar rocks also occur in Ganderia in southern New Brunswick (Fyffe et al. 2009).

Barr et al. (1998) proposed that Neoproterozoic rocks of the Bras d'Or terrane and inferred equivalent units exposed in southern New Brunswick and locally in central Newfoundland represent the "basement" on which Paleozoic Ganderian sedimentary rocks were deposited, and these Paleozoic rocks, which dominate Ganderia elsewhere, were assumed to have been formed mainly from sediments eroded from Neoproterozoic units like those preserved in the Bras d'Or terrane.

The Bras d'Or terrane is separated from the Aspy terrane to the north by a major mylonitic high-strain zone known as the Eastern Highlands Shear Zone (Lin 1995, 2001). This boundary has a long and complex history, and the original relationship between Bras d'Or and Aspy terranes may have been basement and cover (Chen et al. 1995). The Bras d'Or terrane appears to have been thrust to the northwest over the Aspy terrane, and much of the original terrane is missing - the part of Bras d'Or terrane now adjacent to 
the Aspy terrane was unaffected by and hence probably far away from the Silurian to Devonian events which are so prominently recorded in the Aspy terrane. These mid-Paleozoic events are not generally recorded in Bras d'Or terrane rocks, except near the Eastern Highlands Shear Zone, where ${ }^{40} \mathrm{Ar} /{ }^{39} \mathrm{Ar}$ dating revealed overprinting in Neoproterozoic rocks by younger thermal events associated with Bras d'Or-Aspy terrane collision (Reynolds et al. 1989). Although not corroborated by subsequent work (White et al. 2016), Keppie et al. (1998, 2000) reported a Silurian age for a gabbroic-dioritic pluton in the Creignish Hills.

\section{New ages from the Bras d'Or terrane (Appendix A)}

\section{B1. Sample SMB16-222 - Price Point Formation dacitic tuff $(576.5 \pm 2.3 \mathrm{Ma})$}

The Price Point Formation occurs in the southeastern Cape Breton Highlands and consists of mainly intermediate lithic and lithic-crystal tuff with minor andesitic and dacitic flows (Macdonald and Barr 1985). The volcanic rocks were interpreted initially to be of Devonian- Carboniferous age because of inferred correlation with the Fisset Brook Formation (Kelley and Mackasey 1965). However, Macdonald and Barr (1985) suggested a Neoproterozoic age based on interpreted intrusive contacts with plutonic rocks in the area, in particular the Indian Brook granodiorite which yielded a U-Pb (titanite) age of $564 \pm 4 \mathrm{Ma}$ interpreted to be the approximate crystallization age of the granodiorite (Dunning et al. 1990).

Sample SMB16-222 is a black dacitic lithic tuff. Most of the clasts in the tuff consist of plagioclase phenocrysts in very fine-grained quartzofeldspathic groundmass. Zircons in this sample are small, stubby grains and some are very rounded. Zircons are mostly transparent, with oscillatory zoning visible in CL. Some grains have facets and are euhedral. Sample SMB16-222 has a calculated concordia age of $576.5 \pm 2.3 \mathrm{Ma}$ interpreted as the main age of crystallization with an MSWD of 0.090, and a probability of concordance of 0.76 . This age includes 18 grains in the concordia calculation (Fig. 5a).

This age supports the inferred co-magmatic relationship between the volcanic rocks and associated plutons (Grecco and Barr 1999), although it is somewhat older than the dated plutons which have ages between $570 \mathrm{Ma}$ (Birch Plain granite - see below) and $555 \mathrm{Ma}$ (Ingonish River tonalite; Dunning et al. 1990).

\section{B2. Sample SMB14-193 - Birch Plain granite (569.6 $\pm 1.9 \mathrm{Ma}$ )}

The Birch Plain granite is in the northern part of the eastern highlands plutonic belt, intruded by the Cape Smokey pluton dated at $493 \pm 2 \mathrm{Ma}$ (Dunning et al. 1990). Based on map distribution, the presence of variably weak to strong foliation, and the presence of xenoliths in the Indian Brook granodiorite that appear to have been derived from the Birch Plain granite, the Birch Plain granite has been assumed to be older than the Indian Brook unit (Raeside and
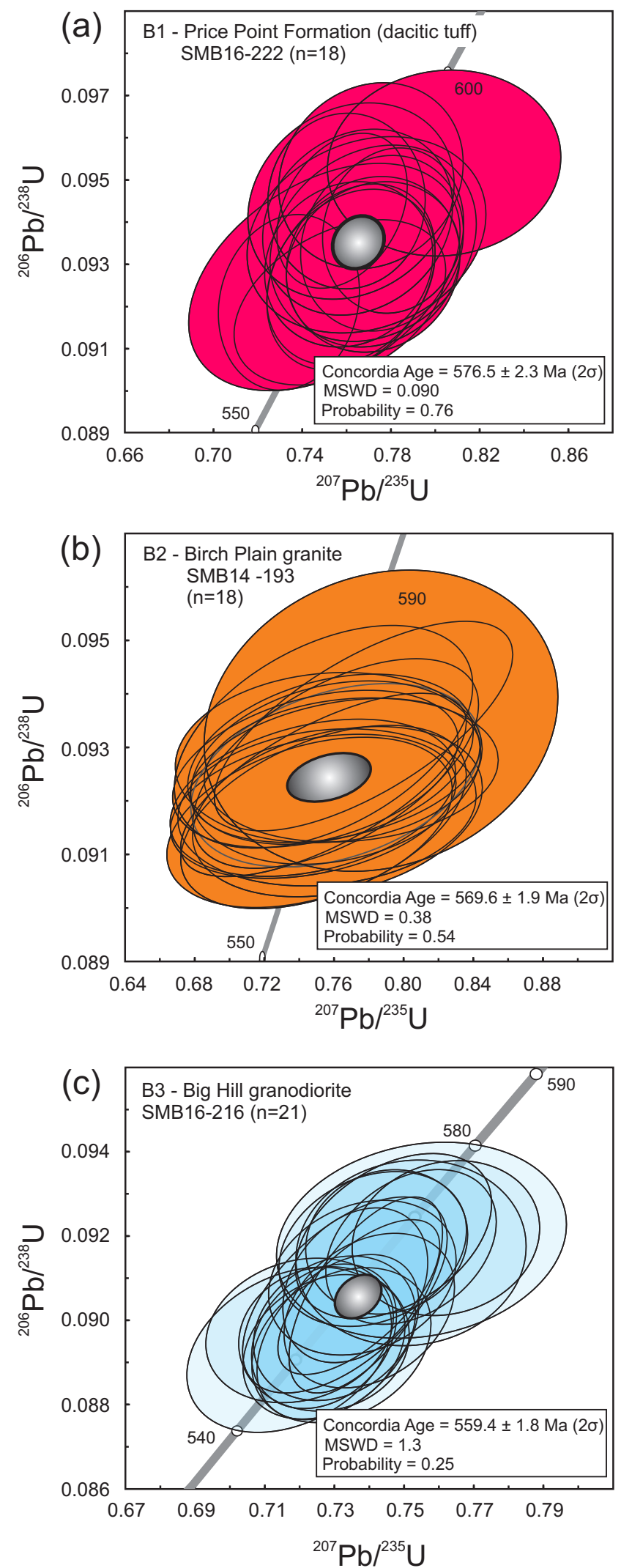

Figure 5. Concordia diagrams for plutons in the Bras d'Or terrane: (a) concordia diagram for zircon from dacitic tuff of the Price Point Formation; (b) concordia diagram for the Birch Plain granite; (c) concordia diagram for the Big Hill granodiorite. 
Barr 1992; Grecco and Barr 1999). It is cut by mafic dykes of unknown age with sharp contacts and well developed chilled margins; possible magma mingling relationships are developed in places.

Sample SMB14-193 was collected from typical roadside outcrops along the access road to the Wreck Cove Hydroelectric Station. It is medium-grained biotite monzogranite typical of the pluton. Mineralogy includes plagioclase, perthitic orthoclase, interstitial deformed polycrystalline quartz, and biotite, mainly altered to chlorite. Allanite and zircon are abundant accessory phases, together with titanite, apatite, and magnetite. Most of the zircons in this sample are in the 10 to $\sim 70 \mu \mathrm{m}$ range. All the grains bigger than $20 \mu \mathrm{m}$ were picked for analysis. The smaller grains are generally euhedral with bipyramidal terminations, and the larger grains rounded or euhedral. Many of the grains contain darker inclusions and are cloudy. In CL most of the grains show oscillatory zoning.

The sample has a calculated concordia age of $569.6 \pm 1.9$ Ma with an MSWD of 0.38 , and a probability of concordance of 0.54 using 18 grains included in the concordia calculation (Fig. 5b). Younger ages from 6 grains do not make an overlapping cluster, and are interpreted as resulting from $\mathrm{Pb}$ loss.

The calculated age of $569.6 \pm 1.9 \mathrm{Ma}$ is slightly younger than the Price Point Formation but overlaps within error the titanite age from the Indian Brook granodiorite.

\section{B3. Sample SMB16-216 - Big Hill granodiorite $(559.4 \pm 1.8 \mathrm{Ma})$}

The Big Hill granodiorite is part of an elongate plutonic belt west of the belt containing the Price Point Formation, Indian Brook granodiorite, and Birch Plain granite. Raeside and Barr (1992) included it in the Goose Cove pluton but Barr and White (2017a) split the area into a northern Goose Cove pluton and a southern Big Hill pluton, although they are probably of similar age. The pluton intruded the Glen Tosh Formation at Big Hill (Barr et al. 2013). It consists of hornblende-biotite granodiorite gradational to granite, locally with microcline megacrysts. Dated sample SMB16216 is monzogranite with plagioclase and chloritized biotite enclosed in interstitial quartz and K-feldspar.

Zircons from this sample are mainly elongate crystals with bipyramidal terminations, although a few rounded grains are present. Grain size varies widely from 50 to 200 $\mu \mathrm{m}$. The grains are slightly cloudy and about one fourth have a yellowish tint. In CL the grains show clear oscillatory zoning. The calculated concordia age of $559.4 \pm 1.8 \mathrm{Ma}$ is interpreted as the main age of crystallization (Fig. 5c), with an MSWD of 1.3, and probability of concordance of 0.25 . This concordia calculation includes 21 grains. A few near-concordant grains that could be inherited occur at 1.3 1.5 , and $1.8 \mathrm{Ga}$ but they are single grains so do not provide unequivocal evidence for inherited ages.

The concordia age of $559.4 \pm 1.8 \mathrm{Ma}$ is slightly younger than the $\mathrm{U}-\mathrm{Pb}$ (titanite) age from the Indian Brook granodiorite (Dunning et al. 1990), although the ages barely overlap within error. Like the ages from the Price Point Formation and Birch Plain granite, this age supports the inferred broadly co-magmatic relationship among the volcanic rocks and plutons in the eastern highlands. Including the new data, these volcanic and plutonic rocks are now represented by $7 \mathrm{U}-\mathrm{Pb}$ zircon ages, oldest of which is the Price Point Formation at ca. $576 \mathrm{Ma}$ and youngest of which is Ingonish River tonalite at $555 \mathrm{Ma}$.

\section{MIRA TERRANE}

\section{Geological setting}

Mira terrane is the only part of Cape Breton Island included in Avalonia (Hibbard et al. 2006). In the northern Appalachian orogen, Avalonian rocks occur in southeastern New England (USA), the Caledonian Highlands of southern New Brunswick, the Cobequid and Antigonish highlands of northern mainland Nova Scotia, the Mira terrane, and the Avalon platform of eastern Newfoundland (Fig. 1 inset). Some authors refer to these areas collectively as West Avalonia, to distinguish them from East Avalonia in the UK and elsewhere in Europe which may be at least in part Ganderian (Schofield et al. 2016). The characteristic rocks of Avalonia are Middle to Late Neoproterozoic volcanic, sedimentary, and plutonic rocks, although specific ages vary from area to area. Most Avalonian areas also include overlying Cambrian to Lower Ordovician clastic sedimentary units. They differ from those in $\mathrm{Br}$ as dOr te rrane in composition and age, and hence Bras d'Or is interpreted to be part of Ganderia, not Avalonia (Barr et al. 1998; Hibbard et al. 2006).

In the Mira terrane, the Neoproterozoic rocks form three belts which previous $\mathrm{U}-\mathrm{Pb}$ dating suggested to be of 3 different ages: Stirling belt (ca. $680 \mathrm{Ma}$ ), Sporting Mountain - East Bay Hills - Coxheath Hills belt (ca. $620 \mathrm{Ma}$ ), and Coastal belt (575 to $550 \mathrm{Ma}$ ). However, the age interpretation was based on relatively few $\mathrm{U}-\mathrm{Pb}$ ages (Barr et al. 1996a) and more recent work had suggested some unrecognized complexities such as detrital zircon grains as young as $\sim 620 \mathrm{Ma}$ in a wacke unit in the Stirling belt and the presence of tuffaceous rocks with an age of $\sim 580 \mathrm{Ma}$ in the East Bay Hills (Willner et al. 2013). All three belts are dominated by mafic to felsic volcanic and volcaniclastic rocks and varying abundances of inter-stratified epiclastic and clastic sedimentary rocks. The Stirling belt has been interpreted to represent an intra-arc or back-arc basin. In contrast, the ca. $620 \mathrm{Ma}$ volcanic, volcaniclastic, and plutonic rocks of the Coxheath Hills, Sporting Mountain, and East Bay Hills belts have petrochemical features typical of high-K calcalkalic suites formed at continental margin subduction zones (Barr et al. 1996a). However, the presence of plutonic rocks of this age in the Stirling belt indicates that these two belts were juxtaposed by that time (Fig. 2). These composite dioritic to granitic ca. $620 \mathrm{Ma}$ plutons are the most extensive plutons in the Mira terrane. Similar ${ }^{40} \mathrm{Ar} /{ }^{39} \mathrm{Ar}$ (horn- 
blende) cooling ages from some of these plutons (Keppie et al. 1990) are consistent with high-level emplacement and rapid cooling.

The ca. $575 \mathrm{Ma}$ mainly tuffaceous volcanic rocks of the Coastal belt (Fourchu Group) appear to be transitional between calc-alkalic and tholeiitic chemical affinity. They are inferred to represent magmas derived early in the development of a ca. $575 \mathrm{Ma}$ northwest-dipping (present coordinates) subduction zone (Barr et al. 1996b). High-level plutonic rocks are only a minor component of the Coastal belt. The other major component of the Coastal belt, the Main-a-Dieu Group, contains lava flows, tuffs, debris flows, and fine-grained epiclastic rocks interpreted to have been deposited in intra-arc basins developed adjacent to the stratovolcanoes represented by the tuffs and flows of the Fourchu Group (Barr 1993; Barr et al. 1996a). The Main-aDieu Group is overlain by mainly clastic marine sedimentary rocks of Cambrian to Early Ordovician age (Barr et al. 1996a).

Devonian plutons are also present in the Mira terrane. They are shallow intrusions with associated porphyry-type, greisen-hosted, and vein-hosted $\mathrm{Cu}-\mathrm{Mo}-\mathrm{Pb}-\mathrm{Ag}-\mathrm{Bi}$ mineralization (Barr and O’Beirne 1981; Barr and Macdonald 1992). Petrological characteristics suggest that they are subduction-related plutons, but no other evidence of a Devonian magmatic arc occurs in southern Cape Breton Island. The apparent arc-signatures could reflect the nature of their source rocks in the roots of a Neoproterozoic arcs, or they could be associated with a more outboard subduction zone relating to juxtaposition of Gondwana with the Meguma terrane (e.g., Moran et al. 2007).

The boundary of the Mira terrane with the Bras d'Or terrane to the north is a "cryptic suture", buried beneath Carboniferous sedimentary rocks or located under water in the Bras d'Or Lakes (Fig. 1). On land, it is rather arbitrarily placed at conveniently located Carboniferous faults through the Boisdale Peninsula. The presence of clasts derived from both Mira terrane and Bras d'Or terrane units in a Middle Devonian conglomerate unit (McAdams Lake Formation) south of this fault shows that the two areas were in proximity by that time (White and Barr 1998). Magnetic and gravity models across the boundary suggest that the Mira terrane has been thrust under Bras d'Or terrane at the boundary (King 2002).

Although a detailed tectonomagmatic history had been developed for the Mira terrane, it was based on ages from relatively few igneous units (Fig. 2). Hence, 5 plutonic units were dated to enhance the database, in particular to provide better age constraints on the Devonian plutons, only one of which had been reliably dated using $\mathrm{U}-\mathrm{Pb}$ in zircon (Lower St. Esprit, 378 +5/-1 Ma; Bevier et al. 1993).

\section{New ages from the Mira terrane (Appendix A)}

M1. Sample SMB16-225 - Irish Cove granodiorite $(619.4 \pm 2.6 \mathrm{Ma})$
Sample SMB16-225 is typical medium-grained granodiorite to monzogranite of the Irish Cove pluton. It consists of subhedral to euhedral plagioclase in a finer-grained assemblage of K-feldspar, quartz, biotite, and hornblende. Minor interstitial granophyre is also present. The granodiorite occurs in close association with and contains abundant xenoliths of volcanic and volcaniclastic rocks of the East Bay Hills Group. It was previously undated but assumed to have an age of ca. $620 \mathrm{Ma}$ based on its petrological similarities to granodiorite of the Chisholm Brook Plutonic Suite in the Stirling belt which yielded U-Pb (zircon) crystallization age of $620+3 /-2 \mathrm{Ma}$ (McMullin 1984; Barr et al. 1990, 1996a). However, a metarhyolite sample from the Rear Irish Cove Formation inferred to have been intruded by the Irish Cove pluton yielded a concordia age of $582 \pm 6 \mathrm{Ma}$, interpreted as the age of extrusion of the rhyolite (Willner et al. 2013).

Zircons from sample SMB16-225 are euhedral and clear, rectangular bipyramidal terminations. In CL most grains have well-defined oscillatory zoning. The sample has a calculated concordia age of $619.4 \pm 2.6 \mathrm{Ma}$ with an MSWD of 4.6 , and probability of concordance of 0.032 , with 18 grains included in the concordia calculation (Fig. 6a).

The reported age is consistent with its correlation with the Chisholm Brook suite but at odds with the age of its host rocks reported by Willner et al. (2013). Additional field mapping is needed to resolve this enigma.

M2. Sample SMB16-217 - MacDougall Point pluton $(625.2 \pm 3.1 \mathrm{Ma}$ with older population at $645.6 \pm 2.7 \mathrm{Ma})$

The MacDougall Point pluton is well exposed in new roadcuts produced by widening of Highway \#4 along the western margin of the East Bay Hills. As mapped by Barr and White (2017b), this small pluton consists of a northern monzodiorite and a southern granitic porphyry. The pluton intruded the Ben Eoin Formation of the East Bay Hills Group. The dated sample is quartz monzodiorite with abundant plagioclase and amphibole and less abundant biotite with interstitial quartz, K-feldspar, and granophyre forming $10-15 \%$ of the rock.

Most of the zircon grains in this sample are clear, euhedral grains in the 20 to $75 \mu \mathrm{m}$ size range. Zircons in the 75 to $150 \mu \mathrm{m}$ range are generally euhedral but with faint reddish staining. In CL most grains show oscillatory zoning. The grains in this sample fall into two clusters that each present as a peak in the probability distribution with a clear separation between them using a $5 \mathrm{Ma}$ bin width (Fig. 6b). The younger cluster has a calculated concordia age of 625.2 $\pm 3.1 \mathrm{Ma}$ with an MSWD of 0.12 , and a probability of concordance of 0.73 with 15 grains included in the calculation (Fig. 6c). The older cluster has a calculated concordia age of $645.6 \pm 2.7 \mathrm{Ma}$ with an MSWD of 0.20 , and a probability of concordance of 0.66 with 12 grains included in the calculation (Figure 6d). We interpret these data as evidence that there are two periods of zircon crystallization represented in the sample, the older zircons representing either anac- 

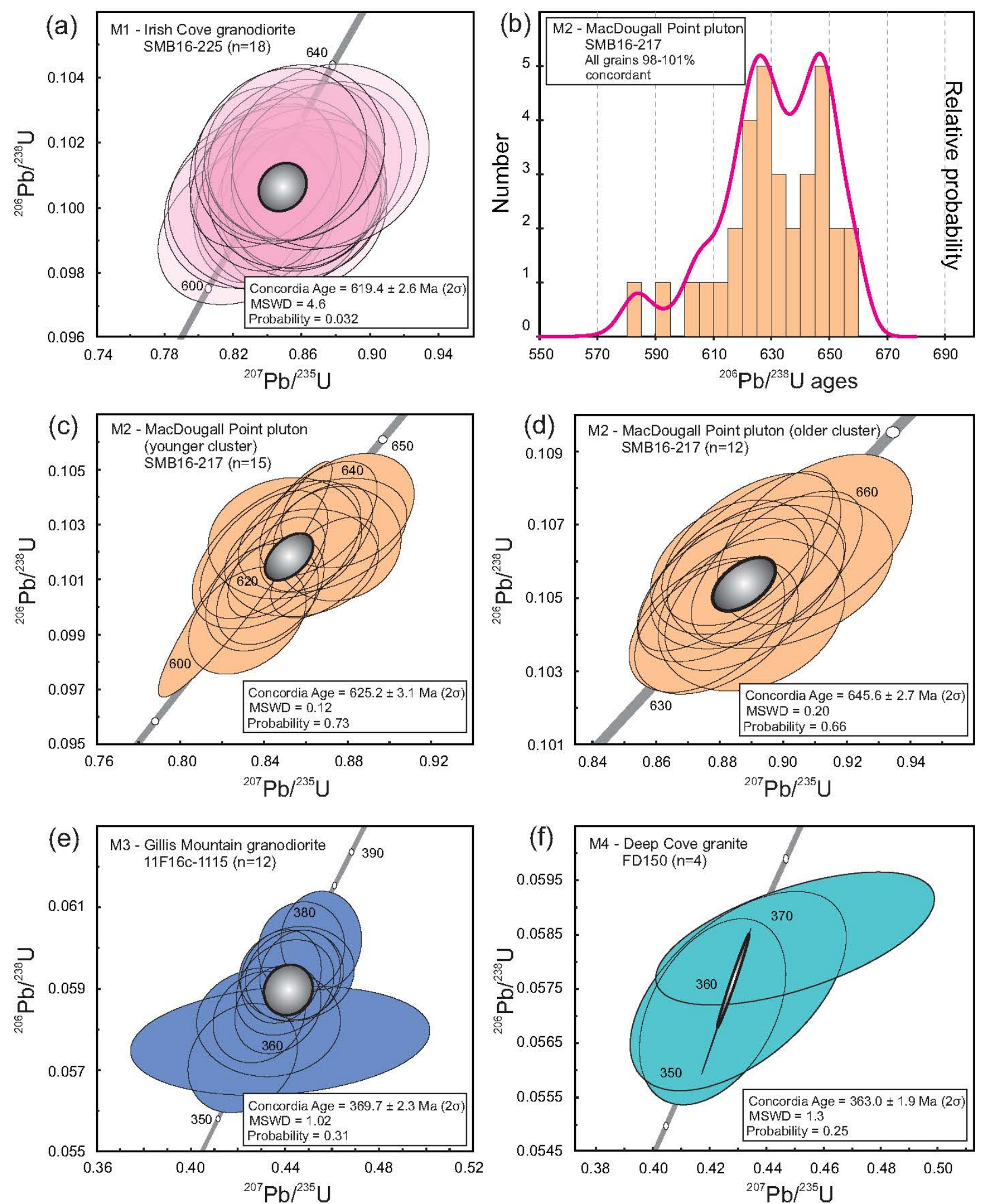

Figure 6. Concordia diagrams and probability plots for plutons in the Mira terrane: (a) concordia diagram for granodiorite of the Irish Cove pluton; (b) probability plot and histogram for quartz granodiorite of the MacDougall Point pluton showing two age peaks; (c) concordia diagram for the younger cluster of 15 zircon grains from the MacDougall Point granodiorite; (d) concordia diagram for the older cluster of 12 zircon grains from the MacDougall Point granodiorite; (e) concordia diagram for porphyritic granite sample 11F16c-1115 from the Gillis Mountain pluton; (f) concordia diagram for granite sample FD150 from the Deep Cove pluton. 
rystic or inherited grains.

The interpreted age of crystallization for the MacDougall Point pluton is consistent with its correlation with the other ca. 620 Ma plutons in the Mira terrane. This date provides a minimum age for the host rocks of the Ben Eoin Formation. Based on location and petrologic similarities, it is probably related to the undated MacEachern Lake pluton farther northeast in the East Bay Hills. Combined with the new age of the Irish Cove pluton reported here (Fig. 6a) and previously published $\mathrm{U}-\mathrm{Pb}$ ages from volcanic and plutonic units, this new age supports the interpretation that most of the volcanic, epiclastic, and plutonic rocks in the East Bay Hills, Sporting Mountain, and Coxheath Hills belts are ca. $620 \mathrm{Ma}$ or older, although the ca. $580 \mathrm{Ma}$ date of Willner et al. (2013) remains the exception.

\section{M3. Sample 11F16c-1115 - Gillis Mountain granodiorite $(370.5 \pm 2.4 \mathrm{Ma})$}

The Gillis Mountain pluton intruded and contact metamorphosed shale, siltstone, and sandstone of early to middle Cambrian age. The contact metamorphic mineral assemblages, together with petrographic features of the pluton, suggest that the pluton was emplaced at a shallow depth (O'Beirne 1979). Gillis Mountain pluton is composite and consists of monzodiorite, porphyritic granite, and finegrained granite as well as dykes of granitic porphyry, finegrained granite, and aplite that occur in the quartz monzodiorite and porphyritic granite units (O’Beirne 1979; Barr and O'Beirne 1981). A previous date of $384 \pm 10 \mathrm{Ma}$ was based on a 12-point $\mathrm{Rb}$-Sr isochron (Cormier 1979).

Sample 11F16c-1115 is a typical porphyritic granodiorite sample. It contains large plagioclase and smaller biotite phenocrysts in a fine-grained granular groundmass of quartz and feldspar. It contains abundant, unusually large, $>200 \mu \mathrm{m}$, euhedral zircon grains, which were dated in situ in a polished section by the method described by Archibald et al. (2013). This sample was not imaged with CL. This sample has a calculated concordia age of $369.7 \pm 2.3 \mathrm{Ma}$ with an MSWD of 1.02, and a probability of concordance of 0.31 with 12 grains included in the calculation (Fig. 6e). This is barely within error of the $\mathrm{Rb}-\mathrm{Sr}$ date and slightly younger than the $\mathrm{U}-\mathrm{Pb}$ (zircon) age of $378+5 /-1 \mathrm{Ma}$ reported from the Lower St. Esprit pluton (Bevier et al. 1993), the only other Devonian pluton dated by the $\mathrm{U}-\mathrm{Pb}$ method in the Mira terrane prior to the present study.

\section{M4. Sample FD150 - Deep Cove granite $(363.0 \pm 1.9 \mathrm{Ma})$}

The Deep Cove pluton is a small pluton (exposed area of less than $0.1 \mathrm{~km}^{2}$ ) that intruded and contact metamorphosed tuffs and flows of the Coastal belt (Ervine 1981; Dennis 1988). The pluton is composed of seriate porphyritic granite with associated granite and granodiorite/tonalite porphyry dykes and aplite dykes (Dennis 1988; Sheard 2007). A whole rock - mineral $\mathrm{Rb}-\mathrm{Sr}$ isochron previously indicated an age of $342 \pm 25 \mathrm{Ma}$ (Cormier 1972; Keppie and Smith 1978), but its petrological similarity to the Gillis
Mountain pluton suggests that they should be the same age (O’Beirne 1979; Barr and Macdonald 1992).

Two samples (FD203A and FD150) from the Deep Cove pluton, both selected from the thesis collection of Dennis (1988), were dated. Both samples consist of porphyritic monzogranite, similar in texture and mineralogy to the dated sample from Gillis Mountain pluton described above, except with more abundant K-feldspar and quartz phenocrysts in addition to plagioclase and biotite.

Zircon grains from sample FD203A contain a large amount of common $\mathrm{Pb}$ as seen in the ${ }^{204} \mathrm{~Pb}$ values recorded, which ranged between 200 and $35000 \mathrm{cps}$. The data are highly discordant in most of the grains. Data from this sample are not useful in determining the crystallization age of the unit so another sample was analyzed. Because the data are highly discordant it was not considered to be appropriate to combine the two datasets from the different samples.

The second sample (FD150) contains more zircon grains than sample FD203A, mostly in the 50 to $100 \mu \mathrm{m}$ size range. Only a few grains are transparent and most are cloudy to brown with abundant inclusions and staining. In CL most grains show oscillatory zoning whereas others are very dark and fluoresce poorly. This sample also contains a large number of grains with common $\mathrm{Pb}$ as determined from the ${ }^{204} \mathrm{~Pb}$ values recorded, which ranged between $0 \mathrm{cps}$ and $2200 \mathrm{cps}$, significantly less than the values obtained from sample FD203A. Only 17 out of the 67 grains analyzed are between 98 and $101 \%$ concordant. The ${ }^{206} \mathrm{~Pb} / 238 \mathrm{U}$ ages show the peak of the distribution around $360 \mathrm{Ma}$. Four grains (three uncorrected, one Anderson-corrected) were used to calculate a concordia age and produced an age of $363.0 \pm$ $1.9 \mathrm{Ma}$ (Fig. 6f) with an MSWD of 1.3 and a probability of concordance of 0.25 .

Given the complexity of the data obtained from this unit and the large and extremely variable quantities of common $\mathrm{Pb}$ contained in the zircon grains, this is the most robust interpretation that can be made using the available data.

\section{M5. Sample SMB16-214 - Salmon River rhyolite porphyry} (367.4 $\pm 3.4 \mathrm{Ma}$ with inheritance of $612.7 \pm 5.3 \mathrm{Ma}$ )

The Salmon River pluton outcrops over a large area in the northern part of the Stirling belt. It consists of relatively homogeneous rhyolite porphyry (or porphyritic fine-grained granite). Phenocrysts include sanidine, quartz, plagioclase, and rarely altered muscovite of possible xenocrystic origin, given the abundance of mica in the Cambrian host rocks. The groundmass is fine-grained and granular and consists of K-feldspar, quartz, biotite (mostly altered to chlorite), and abundant sericite. The pluton intruded granodioritic rocks of the ca. $620 \mathrm{Ma}$ Chisholm Brook suite and Ediacaran-Cambrian coarse clastic rocks. Detrital muscovite in the latter rocks has undergone Silurian or younger partial argon loss (P. Reynolds, unpublished data, 1991). Locally concordant intrusive contacts and satellite sills in the Cambrian clastic rocks suggest that the pluton has laccolithic or sheet-like form (McMullin 1984). A Devonian (or younger) 
age was indicated previously by an $\mathrm{Rb}-\mathrm{Sr}$ isochron at 368 $\pm 30 \mathrm{Ma}$ (Barr et al. 1984). U-Pb dating of zircon from the porphyry was attempted but yielded only sparse xenocrystic zircons of Archean age (Doig et al. 1990). The pluton is nonconformably overlain by Upper Carboniferous sandstone of the Silver Mine Formation which hosts the Yava stratabound lead deposit, mined in the 1980s. The lead in the deposits has been interpreted to have been derived from the rhyolite porphyry and/or the Chisholm Brook suite (Sangster and Vaillancourt 1990).

Three samples from the Salmon River pluton were dated: DM141 (data only in Supplementary Files), SMB14-192, and SMB16-214; the last sample was the most successful, both in terms of zircon recovery and data quality and is discussed here first.

Sample SMB16-214 contained few zircon grains and most are tiny $(<30 \mu \mathrm{m})$ and acicular. Grains in the 50 to $100 \mu \mathrm{m}$ range were picked for analysis. They are rectangular with some euhedral crystals, and range from transparent to brown with abundant dark inclusions and staining. Some larger fragments of broken crystals were also picked for analysis. In CL some of the grains are dark with little internal definition, but most show faint oscillatory zoning. This sample has a calculated concordia age of $367.4 \pm 3.4$ Ma with an MSWD of 2.1, and a probability of concordance of 0.15 with 11 grains included in the calculation (Fig. 7a). A spread of younger ages (3 grains) does not make an overlapping cluster, and is interpreted as resulting from $\mathrm{Pb}$ loss.

Zircons obtain from sample DM141 contained a large amount of common $\mathrm{Pb}$ as seen in the ${ }^{204} \mathrm{~Pb}$ values recorded, which ranged between 200 and 33000 cps (Supplementary Data File). The $d$ ata a re h ighly d iscordant, a nd only t wo out of 44 grains are 98 to $101 \%$ concordant. Data from this sample are not useful in determining the crystallization age of the unit and because the data are highly discordant it was not appropriate to combine this dataset with those from the other samples.

The third sample, SMB14-192, contained very few zircon grains and most are in the size range 10 to $20 \mu \mathrm{m}$ and too small for analysis. All grains bigger than $20 \mu \mathrm{m}$ were picked for analysis. They are mostly euhedral, with bipyramidal terminations, but also included a few rounded or broken grains. In CL the grains show oscillatory zoning. Only 12 grains could be analyzed, four of which are 98 to $101 \%$ concordant. Of those grains, the three that overlap within error give a concordia age $612.7 \pm 5.3 \mathrm{Ma}$ with an MSWD of 1.3, and a probability of concordance of 0.25 (Fig. 7b). These data are interpreted as representing an inherited population of zircons with an age older than the interpreted date of crystallization as described above for sample SMB16-214 from the same unit.

The combined probability distribution diagram for samples SMB16-214 and SMB14-192 (Fig. 7c) suggests a history of at least two episodes of zircon crystallization, where inherited zircons were erupted together with newly crystallized grains in the younger episode of igneous activity.
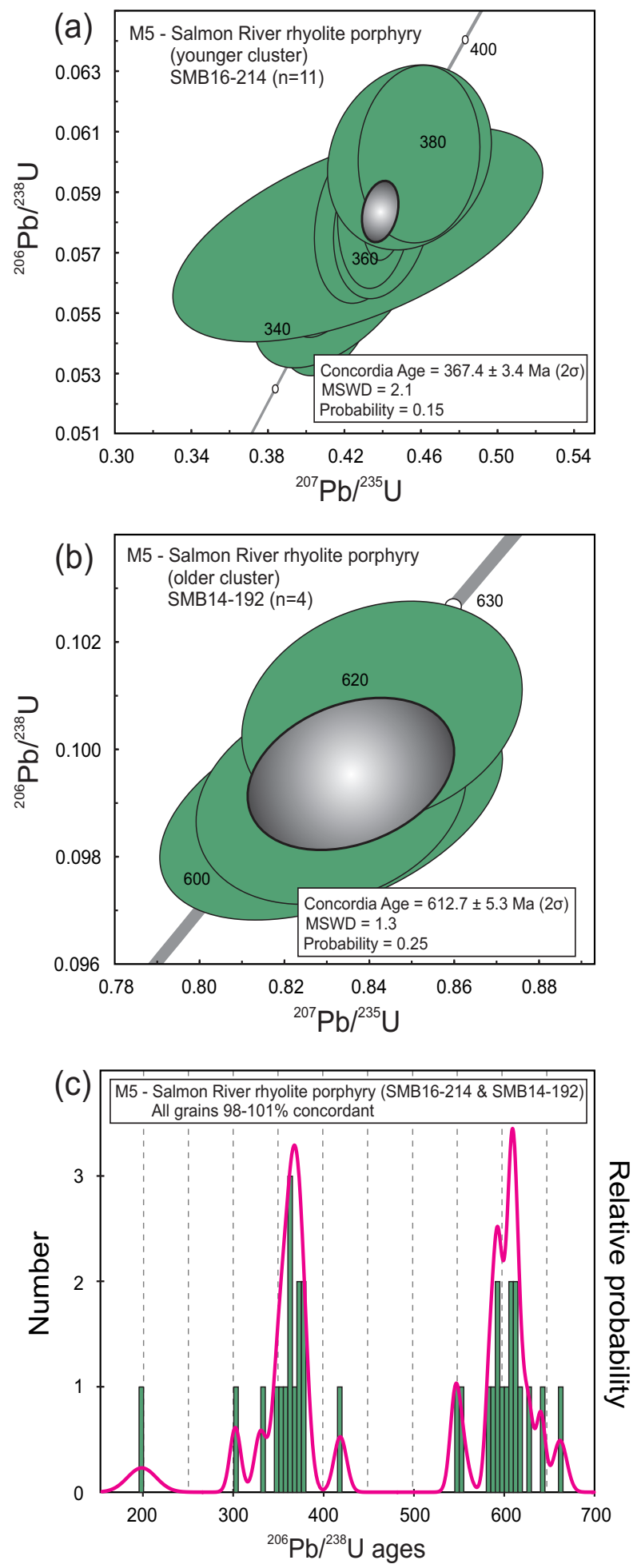

Figure 7. Concordia diagrams and probability plot for the Salmon River pluton in the Mira terrane: (a) concordia diagram for the young cluster of 11 zircon grains in rhyolite porphyry sample SMB16-214; (b) concordia diagram for the older cluster of 4 zircon grains from rhyolite porphyry sample SMB14-192; (c) concordia diagram for all concordant and near-concordant zircon grains in samples SMB16-214 and SMB14-192 combined showing two age peaks. 
The two different age populations and the variability of the common $\mathrm{Pb}$ content in the different samples also serve as a reminder of the natural variability in chemistry and zircon crystallization history that can be present in one mapped unit. However, we found no evidence for the Archean ages reported by Doig et al. (1990).

\section{DISCUSSION}

\section{Aspy terrane}

The new $\mathrm{U}-\mathrm{Pb}$ ages from Aspy terrane reported here, combined with those reported by Slaman et al. (2017), provide a new perspective on Aspy terrane evolution. The new data corroborate the interpretation that the terrane is dominated by Silurian and Devonian igneous rocks and show that the Early Silurian and Late Devonian were times of abundant activity, with a gap in the mid-Devonian - only one pluton has an age between $400 \mathrm{Ma}$ and $380 \mathrm{Ma}$ (Fig. 8a). The previous imprecise age of ca. $550 \mathrm{Ma}$ is now better constrained by two ages of $567 \mathrm{Ma}$ from the former Cheticamp pluton (Slaman et al. 2017). These ca. 567 Ma plutonic units in the Chéticamp area are similar in age and tectonic setting to a suite of ca. 565 to $563 \mathrm{Ma}$ bimodal volcanic rocks (Sandy Brook Group) and comagmatic plutonic units (Crippleback Lake, Valentine Lake, and Lemottes Lake plutons) that occur along the western margin of Ganderia in the Exploits Subzone of central Newfoundland (Rogers et al. 2006; van Staal 2007). They may be related to fault-bounded areas of coeval igneous rocks in the Hermitage Flexure in southern Newfoundland (Lin et al. 2007). Like rocks of similar ages in the Bras d'Or and Brookville terranes, these rocks have been considered part of Ganderian basement (e.g., van Staal et al. 1996; Barr et al. 1998; van Staal and Barr 2012; White et al. 2016). Other components of that pluton have been shown to be Ordovician, with 5 ages in the range 490-475 Ma (Slaman et al. 2017; this study). These are the first such ages to be obtained in the Aspy terrane. They coincide with the age suggested for the Penobscot arc, identified in the Exploits Subzone in Newfoundland and New Brunswick (e.g., van Staal 2007; Zagorevski et al. 2007, 2010; van Staal and Barr 2012).

Although the petrographic features and tectonic settings of these rocks are still being assessed, comparison with earlier interpretations (e.g., Barr 1990; Slaman et al. 2017; Barr and Jamieson 1991) indicate that the Aspy terrane records at least 4 separate (in time) subduction/collision-related magmatic events that overlap in space, as well as more widespread post-orogenic magmatism that overlaps in time with the youngest (mid-Devonian) collisional events.

\section{Bras d'Or terrane}

The new $\mathrm{U}-\mathrm{Pb}$ results confirm the importance of a Late Ediacaran (570 to $540 \mathrm{Ma}$ ) subduction-related magmatic event throughout the Bras d'Or terrane (Fig. 8b). The over- lap in age with plutons in the western part of the Aspy terrane supports a link between Aspy and Bras d'Or terranes as previously proposed (Lin 1993; Slaman et al. 2017), although the overall age pattern in the two terranes is very different (Fig. 8b). An important result is the confirmation that the volcanic rocks of the Price Point Formation are cogenetic with the abundant plutons of the southeastern highlands, thus supporting the interpretation that the area preserved a depth-section of the crust from $>25 \mathrm{~km}$ in the north adjacent to the Eastern Highlands Shear Zone to epizonal plutons and volcanic rocks in the south (Farrow and Barr 1992). The new results also confirm the importance of a younger magmatic event in the Bras d'Or terrane at about $500 \mathrm{Ma}$, now represented by 7 ages from both volcanic and plutonic rocks between 520 and $490 \mathrm{Ma}$ (Fig. 8b). So far, this magmatic event is recorded only in the eastern part of the terrane, and has been attributed to rifting of Ganderia from Gondwana.

The only younger date in the Bras d'Or terrane is a Silurian age of $438 \pm 2$ Ma reported by Keppie et al. (1998, 2000) for a sample from a gabbro-diorite body in the Skye Mountain pluton in the Creignish Hills. However, the specific sample location was not reported, and the significance of this age remains uncertain (White et al. 2016).

\section{Mira terrane}

The new $\mathrm{U}-\mathrm{Pb}$ data from Mira terrane support previous work which indicated 3 belts of volcanic-plutonic rocks with ages of ca. $680 \mathrm{Ma}, 620 \mathrm{Ma}$, and $560 \mathrm{Ma}$ dominate the terrane (Fig. 8c). However, considering the size of the terrane, more dating is needed to better constrain the distribution of rocks of the three age groups, in particular the extent of ca. $580 \mathrm{Ma}$ volcanic rocks detected by Willner et al. (2013) in the East Bay Hills belt.

The new data provide much improved constraints on the timing of Devonian magmatism in the Mira terrane, with 4 ages between 370 and $363 \mathrm{Ma}$. Because of the association of this magmatic event with economic mineralization, more petrological work is needed to better constrain the tectonic setting of these apparently subduction-related plutons (Barr and Macdonald 1992).

\section{CONCLUSIONS}

The new ages reported here are a major step toward understanding the geological history of Cape Breton Island and its role in the development of the northern Appalachian orogen. They provide the basis for further petrological studies and tectonic interpretations now in progress (e.g., Moning et al. 2018). Without reliable age constraints, tectonic interpretations and regional correlations are only speculations. It is apparent from the range of ages that rocks with similar petrological features formed in similar tectonic settings but at different times. Because plutonic rocks provide record of not only tectonic setting but also their 

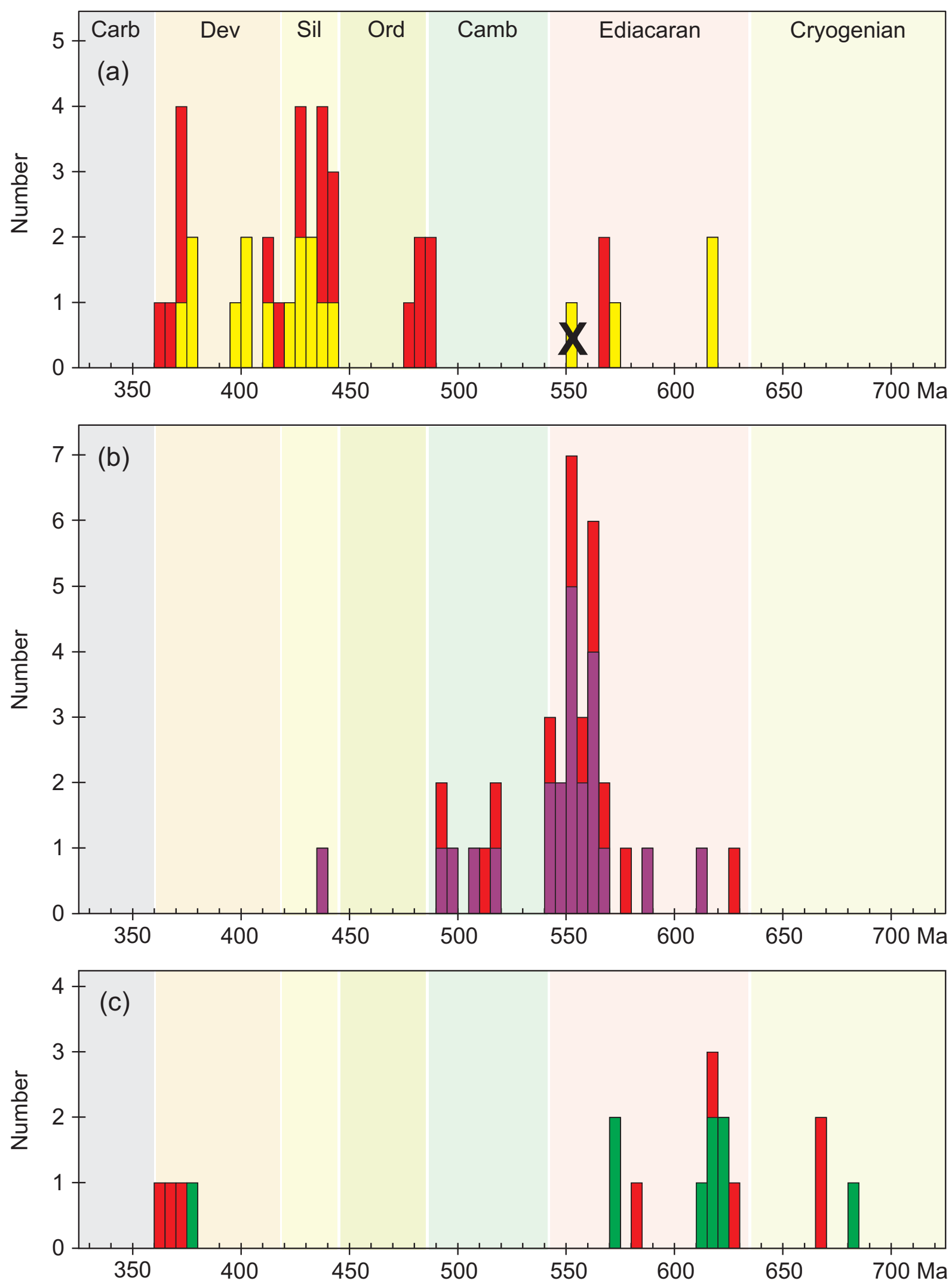

Figure 8. Histograms showing pre-2010 (in yellow, purple, and green) and current (in red) $\mathrm{U}-\mathrm{Pb}$ igneous crystallization ages, including those reported here, for igneous rock units in the (a) Aspy terrane, (b) Bras d'Or terrane, and (c) Mira terrane. Current Bras d'Or terrane compilation also includes new ages from van Rooyen et al. (2017) and van Rooyen, personal communication, 2018). 
crustal sources, ultimately these data will provide the answers that we are seeking. It is apparent that ages are needed from almost every pluton, because even with careful mapping and petrological studies, plutons of different ages can appear very similar.

\section{ACKNOWLEDGEMENTS}

We thank Brandon Boucher and Chris McFarlane for assisting D. van Rooyen with the U-Pb dating at the University of New Brunswick and for providing invaluable advice in processing and interpreting the age data. We also thank journal reviewers Michael Dorais and John Waldron and editor David West for their insightful comments and suggestions which resulted in significant improvements in the manuscript. This work was funded in part by a Natural Sciences and Engineering Research Council of Canada Discovery Grant to Sandra Barr, a Research Policy Grant from Cape Breton University to Deanne van Rooyen, the Nova Scotia Department of Natural Resources through Chris White, and a research contract through Targeted Geoscience Initiative -5 program of the Geological Survey of Canada.

\section{REFERENCES}

Anderson, T. 2002.Correction of common lead in $\mathrm{U}-\mathrm{Pb}$ analyses that do not report ${ }^{204} \mathrm{~Pb}$. Chemical Geology, 192, pp. 59-79. https://doi.org/10.1016/S00092541(02)00195-X

Archibald, D.B., Barr, S.M., Murphy, J.B., White, C.E., MacHattie, T.G., Escarraga, E.A., Hamilton, M.A., and McFarlane, C.R.M. 2013. Field relationships, petrology, age, and tectonic setting of the Ordovician West Barneys River Plutonic Suite, southern Antigonish Highlands, Nova Scotia, Canada. Canadian Journal of Earth Sciences, 50, pp. 727-745. https://doi.org/10.1139/cjes2012-0158

Barr, S.M. 1990. Granitoid rocks and terrane characterization: an example from the northern Appalachian Orogen. Geological Journal, 25, pp. 295-304. https://doi.org/10.1002/gj.3350250312

Barr, S.M. 1993. Geochemistry and tectonic setting of Late Precambrian volcanic and plutonic rocks in southeastern Cape Breton Island, Nova Scotia. Canadian Journal of Earth Sciences, 30, pp. 1147-1154. https://doi.org/10.1139/e93-097

Barr, S.M. 2010. Granites and terranes in Cape Breton Island. In Eurogranites 2010 Field Excursion Guidebook, Nova Scotia. Edited by D.B. Clarke. Atlantic Geoscience Society Special Publication Number 37, pp. 63-88.

Barr, S.M. and Hegner, E. 1992. Nd isotopic compositions of felsic igneous rocks in Cape Breton Island, Nova Scotia: implications for petrogenesis and terrane analysis. Canadian Journal of Earth Sciences, 29, pp. 650-657. https://doi.org/10.1139/e92-056
Barr, S.M. and Jamieson, R.A. 1991. Tectonic setting and regional correlations of Ordovician-Silurian metavolcanic rocks of the Aspy Terrane, Cape Breton Island, Nova Scotia: Canadian Journal of Earth Sciences, 28, pp. 1769-1779. https://doi.org/10.1139/ e91-158

Barr, S.M. and Macdonald, A.S. 1992. Devonian plutonism and related mineralization in southeastern Cape Breton Island. Atlantic Geology, 28, pp. 101-113. https://doi. org/10.4138/1853

Barr, S.M. and O'Beirne, A.M. 1981. Petrology of the Gillis Mountain pluton, Cape Breton Island, Nova Scotia. Canadian Journal of Earth Sciences, 18, pp. 394-404. https://doi.org/10.1139/e81-032

Barr, S.M. and Peterson, K. 1998. Field relations and petrology of the Fisset Brook Formation in the Cheticamp area, western Cape Breton Island, Nova Scotia. Atlantic Geology, 34, pp. 121-132. https://doi. org $/ 10.4138 / 2043$

Barr, S.M. and Raeside, R.P. 1989. Tectono-stratigraphic divisions of Cape Breton Island, Nova Scotia. Geology, 17, pp. 822-825. https://doi.org/10.1130/00917613(1989)017<0822:TSTICB >2.3.CO;2

Barr, S.M. and White, C.E. 1996. Contrastsin late Precambrianearly Paleozoic tectonothermal history between Avalon Composite Terrane sensu stricto and other periGondwanan terranes in southern New Brunswick and Cape Breton Island, Canada. In Avalonian and related peri-Gondwanan terranes of the Circum-North Atlantic. Edited by R.D. Nance and M.D. Thompson. Geological Society of America Special Paper 304, pp. 95-108. https:// doi.org/10.1130/0-8137-2304-3.95

Barr, S.M. and White, C. E. 2017a. Overview map showing locations of bedrock geology maps for Cape Breton Island, Nova Scotia. Nova Scotia Department of Natural Resources, Geoscience and Mines Branch, Open File Map ME 2017-006, scale 1:220 000.

Barr, S. M. and White, C. E. 2017b. Bedrock geology legend for Cape Breton Island, Nova Scotia; Nova Scotia Department of Natural Resources, Geoscience and Mines Branch, Open File Illustration ME 2017-001.

Barr, S.M., O'Reilly, G.A., and O'Beirne, A.M. 1982. Geology and geochemistry of selected granitoid plutons of Cape Breton Island. Nova Scotia Department of Mines and Energy Paper 82 1, 177 p. https://doi. org/10.4095/111378

Barr, S.M., Sangster, D.F., and Cormier, R.F. 1984. Petrology of early Cambrian and Devono- Carboniferous intrusions in the Loch Lomond complex, southeastern Cape Breton Island, Nova Scotia. In Current Research, Part A, Geological Survey of Canada, Paper 84 1A, pp. 203-211.

Barr, S.M., Dunning, G.R., Raeside, R.P., and Jamieson, R.A. 1990. Contrasting $\mathrm{U}-\mathrm{Pb}$ ages from plutons in the Bras d'Or and Mira terranes of Cape Breton Island, Nova Scotia: Canadian Journal of Earth Sciences, 27, pp. 1200-1208. https://doi.org/10.1139/e90-127 
Barr, S.M., Jamieson, R.A., and Raeside, R.P. 1992. Geology of northern Cape Breton Island, Nova Scotia. Geological Survey of Canada, Map 1752A, scale 1:100 000.

Barr, S.M., Macdonald, A.S., Arnott, A.A., and Dunning, G.R. 1995. The Fisset Brook Formation in the Lake Ainslie - Gillanders Mountain area, Cape Breton Island, Nova Scotia. Atlantic Geology, 31, pp. 127-139. https://doi.org/10.4138/2107

Barr, S.M., White, C.E., and Macdonald, A.S. 1996 a. Stratigraphy, tectonic setting, and geological history of Late Precambrian volcanic-sedimentary-plutonic belts in southeastern Cape Breton Island, Nova Scotia: Geological Survey of Canada Bulletin 468, 84 p. https:// doi.org/10.4095/208235

Barr, S.M., Raeside, R.P., Miller, B.V., and White, C.E. 1996 b. Terrane evolution and accretion in Cape Breton Island, Nova Scotia. In New perspectives in the Appalachian orogeny. Edited by J. Hibbard, P. Cawood, S. ColmanSadd, and C. van Staal. Geological Association of Canada Special Paper 41, pp. 391-407.

Barr, S.M., Raeside, R.P., and White, C.E. 1998. Geological correlations between Cape Breton Island and Newfoundland, northern Appalachian orogeny. Canadian Journal of Earth Sciences, 35, pp. 1252-1270. https://doi.org/10.1139/e98-016

Barr, S.M., Pin, C., McMullin, D.W.A., and White, C.E. 2013. Whole-rock chemical and $\mathrm{Nd}$ isotopic composition of a Late Proterozoic metasedimentary sequence in Ganderia: Kellys Mountain, Bras d'Or terrane, Nova Scotia, Canada. Atlantic Geology, 49, pp. 57-69. https://doi.org/10.4138/atlgeol.2013.002

Bevier, M.L., Barr, S.M., White, C.E., and Macdonald, A.S. 1993. U-Pb geochronologic constraints on the volcanic evolution of the Mira (Avalon) terrane, southeastern Cape Breton Island, Nova Scotia. Canadian Journal of Earth Sciences, 30, pp. 1-10. https://doi.org/10.1139/ e93-001

Chen, Y.D., Lin, S., and van Staal, C.R. 1995. Detrital zircon geochronology of a conglomerate in the northeastern Cape Breton Highlands: implications for the relationships between terranes in Cape Breton Island, the Canadian Appalachians. Canadian Journal of Earth Sciences, 32, pp. 216-223. https://doi.org/10.1139/e95-018

Cormier, R.F. 1972. Radiometric ages of granitic rocks, Cape Breton Island, Nova Scotia. Canadian Journal of Earth Sciences, 20, pp. 355-363. https://doi.org/10.1139/e72093

Cormier, R.F. 1979. Rubidium/strontium isochron ages of Nova Scotian granitoid plutons. Nova Scotia Department of Mines and Energy, Report 79-1, pp. 143-147

Dennis, F.A.R. 1988. Petrology and mineralization of the Deep Cove pPluton, Gabarus Bay, Cape Breton Island, Nova Scotia. Unpublished M.Sc. thesis, Acadia University, Wolfville, Nova Scotia, 209 p.
Doig, R., Murphy, J.B., and Barr, S.M. 1990. Archaean and early Proterozoic detrital zircon in Paleozoic silicic rocks of Cape Breton Island and Cobequid Highlands, Nova Scotia: preliminary results. In Nova Scotia Department of Mines, Report 90-3, p. 37.

Dunning, G.R., Barr, S.M., Raeside, R.P., and Jamieson, R.A. 1990. U-Pb zircon, titanite, and monazite ages in the Bras d'Or and Aspy terranes of Cape Breton Island, Nova Scotia: implications for magmatic and metamorphic history: Geological Society of America Bulletin, 102, pp. 322-330. https://doi. org/10.1130/0016-7606(1990)102<0322:UPZTAM>2. 3.CO;2

Dunning, G.R., Barr, S.M., Giles, P.S., McGregor, D.C., Pe-Piper, G., and Piper, D.J.W. 2002. Chronology of Devonian to early Carboniferous rifting and igneous activity in southern Magdalen Basin based on $\mathrm{U}-\mathrm{Pb}$ (zircon) dating. Canadian Journal of Earth Sciences, 39, pp. 1219-1237. https://doi.org/10.1139/e02-037

Ervine, W.B. 1981. Base Metals, Deep Cove, Cape Breton County, Nova Scotia. A geologic evaluation of the Deep Cove-Eagle Head area Gabarus Bay, Cape Breton Island, Nova Scotia. Nova Scotia Department of Mines and Energy. Assessment Report ME 11F/16D 07-C31(10), $41 \mathrm{p}$.

Farrow, C.E.G. and Barr, S.M. 1992. Petrology of highalumina hornblende and magmatic epidote-bearing plutons, southeastern Cape Breton Highlands, Nova Scotia. Canadian Mineralogist, 30, 377-392.

French, V.A. 1985. Geology of the Gillanders Mountain Intrusive complex and satellite plutons, Lake Ainslie area, Cape Breton Island, Nova Scotia. Unpublished M.Sc thesis, Acadia University, Wolfville. Nova Scotia, $237 \mathrm{p}$.

Fyffe, L.R., Barr, S.M., Johnson, S.C., McLeod, M.J., McNicoll, V.J., Valverde-Vaquero, P., van Staal, C.R., and White, C.E. 2009. Detrital zircon ages from Neoproterozoic and Early Paleozoic conglomerate and sandstone units of New Brunswick and coastal Maine: paleogeographic implications for Ganderia and the continental margin of western Gondwana. Atlantic Geology, 45, pp. 110-144. https://doi.org/10.4138/ atlgeol.2009.006

Geological map of the province of Nova Scotia. 1965. Nova Scotia department of Mines. Halifax, Nova Scotia, scale 1:506 880 .

Grecco, L. and Barr, S.M. 1999. Late Neoproterozoic granitoid and metavolcanic rocks of the Indian Brook area, southeastern Cape Breton Highlands, Nova Scotia. Atlantic Geology, 35, pp. 43-57. https://doi. org/10.4138/2023

Heaman, L.M., Erdmer, P., and Owen, J.V. 2002. U-Pb geochronologic constraints on the crustal evolution of the Long Range Inlier, Newfoundland. Canadian Journal of Earth Sciences, 39, pp. 845-865. https://doi. org/10.1139/e02-015 
Hibbard, J.P., van Staal, C.R., Rankin, D., and Williams, H. 2006, Lithotectonic map of the Appalachian orogen (north), Canada-United States of America: Geological Survey of Canada Map 02041A, scale 1:1500 000.

Hibbard, J.P., van Staal, C.R., and Rankin, D.W. 2007. A comparative analysis of pre-Silurian building blocks of the Northern and Southern Appalachians. American Journal of Science, 307, pp. 23-45. https://doi. org/10.2475/01.2007.02

Horne, R., Dunning, G.R., and Jamieson, R.A. 2003. U$\mathrm{Pb}$ age data for Belle Cote Road orthogneiss, Taylors Barren pluton, and Bothan Brook pluton, southern Cape Breton Highlands (NTS 11K/10,11K/11): igneous ages and constraints on the age of host units and deformational history. In Mineral Resources Branch, Report of Activities 2002. Nova Scotia Department of Natural Resources Report 2003-1, pp. 57-68.

Jamieson, R.A., van Breemen, O., Sullivan, R.W., and Currie, K.L. 1986. The age of igneous and metamorphic events in the western Cape Breton Highlands, Nova Scotia: Canadian Journal of Earth Sciences, 23, pp. 1891-1901. https://doi.org/10.1139/e86-177

Kelley, D.G. and Mackasey, W.O. 1965. Basal Mississippian volcanic rocks in Cape Breton Island. Geological Survey of Canada, Paper 64-34, 10 p. https://doi. org/10.4095/101005

Keppie, J. D. and Smith, P. K. 1978. Compilation of isotopic age data of Nova Scotia. Nova Scotia Department of Mines, Report 78-4, 54 p.

Keppie, J.D., Dallmeyer, R.D., and Murphy, J.B. 1990. Tectonic implications of ${ }^{40} \mathrm{Ar} /{ }^{39} \mathrm{Ar}$ hornblende ages from late Proterozoic-Cambrian plutons in the Avalon Composite Terrane, Nova Scotia, Canada. Geological Society of America Bulletin, 102, pp. 516-528. https:// doi.org/10.1130/0016-7606(1990)102<0516:TIOAAH $>2.3 . \mathrm{CO} ; 2$

Keppie, J.D., Dallmeyer, R.D., and Krogh, T.E. 1992. U-Pb and ${ }^{40} \mathrm{Ar} /{ }^{39} \mathrm{Ar}$ mineral ages from Cape North, northern Cape Breton Island: implications for accretion of the Avalon Composite Terrane. Canadian Journal of Earth Sciences, 29. pp. 277-295. https://doi.org/10.1139/e92025

Keppie, J.D., Dostal, J., Davis, D.W., and Horton, D.A. 1998. Earliest Silurian suprasubduction magmatism in central Cape Breton Island. Atlantic Geology, 34, pp. 113-120. https://doi.org/10.4138/2042

Keppie, J.D., Dostal, J., Dallmeyer, R.D., and Doig, R. 2000. Superposed Neoproterozoic and Silurian magmatic arcs in central Cape Breton Island, Canada: geochemical and geochronological constraints: Geological Magazine, 137, pp. 137-153. https://doi. org/10.1017/S0016756800003769

King, M.S. 2002. A geophysical interpretation of the MiraBras d'Or terrane boundary, southeastern Cape Breton Island, Nova Scotia. Unpublished M.Sc thesis, Acadia University, Wolfville, Nova Scotia, 195 p.
Lin, S. 1993. Relationship between the Aspy and Bras d'Or "terranes" in the northeastern Cape Breton Highlands, Nova Scotia. Canadian Journal of Earth Sciences, 30, pp. 1773-1781. https://doi.org/10.1139/e93-157

Lin, S. 1995. Structural evolution and tectonic significance of the Eastern Highlands shear zone in Cape Breton Island, the Canadian Appalachians: Canadian Journal of Earth Sciences, 32, pp. 545-554. https://doi. org/10.1139/e95-046

Lin, S. 2001. ${ }^{40} \mathrm{Ar} /{ }^{39} \mathrm{Ar}$ age pattern associated with differential uplift along the Eastern Highlands shear zone, Cape Breton Island, Canadian Appalachians. Journal of Structural Geology, 23, pp. 1031-1042. https://doi.org/10.1016/S0191-8141(00)00174-7

Lin, S., van Staal, C.R., and Dube, B. 1994. Promontorypromontory collision in the Canadian Appalachians. Geology,22,pp.897-900.https://doi.org/10.1130/00917613(1994)022<0897:PPCITC>2.3.CO;2

Lin, S., Davis, D.W., Barr, S.M., van Staal, C.R., Chen, Y., and Constantin, M. 2007. U-Pb geochronological constraints on the evolution of the Aspy terrane, Cape Breton Island: Implications for relationships between Aspy and Bras d'Or terranes and Ganderia in the Canadian Appalachians. American Journal of Science, 307, pp. 371-398. https://doi.org/10.2475/02.2007.03

Ludwig, K.R. 2003. Isoplot 3.75: A Geochronological Toolkit for Microsoft Excel; Berkeley Geochronological Center. <http://www.bgc.org/isoplot_etc/isoplot/ Isoplot3_75files.zip>

Ludwig, K.R. 2012. Isoplot 4.15: A Geochronological Toolkit for Microsoft Excel. Berkeley Geochronological Center. <http://www.bgc.org/isoplot_etc/isoplot/ Isoplot4_15files.zip >

Macdonald, A.S. and Barr, S.M. 1985. Geology and age of polymetallic mineral occurrences in volcanic and granitoid rocks, St. Anns area, Cape Breton Island, Nova Scotia. In Current Research, Part B, Geological Survey of Canada Paper 85 1B, pp. 117-124.

McFarlane, C.R.M. and Luo, Y. 2012. Modern analytical facilities: U-Pb geochronology using 193nm Excimer LA-ICP-MS optimized for in situ accessory mineral dating in thin sections. Geoscience Canada, 39, pp. $158-172$.

McMullin, D.W.A. 1984. The Loch Lomond plutonic complex, Cape Breton Island, Nova Scotia. Unpublished M.Sc thesis, Acadia University, Wolfville, Nova Scotia, 239 p.

Miller, B.V. and Barr, S.M. 2000. Petrology and geochemistry of a Mesoproterozoic basement fragment in the Appalachian orogen: Blair River inlier, Nova Scotia, Canada. Journal of Petrology, 41, pp. 1777-1804. https://doi.org/10.1093/petrology/41.12.1777

Miller, B.V., Dunning, G.R., Barr, S.M., Raeside, R.P., and Jamieson, R.A. 1996. Magmatism and metamorphism in a Grenvillian fragment; $\mathrm{U}-\mathrm{Pb}$ and ${ }^{40} \mathrm{Ar} /{ }^{39} \mathrm{Ar}$ ages from the Blair River Complex, northern Cape Breton 
Island, Nova Scotia, Canada. Geological Society of America Bulletin, 108, pp. 127-140. https://doi. org/10.1130/0016-7606(1996)108<0127:MAMIAG $>2$. 3.CO;2

Moning, A., Barr, S.M., White C.E., Sombini dos Santos, G., and van Rooyen, D. 2018. Factors controlling intrusionrelated mineralization in Cape Breton Island, Nova Scotia: a comparison of Silurian-Devonian plutons in Ganderia and Avalonia. . In Targeted Geoscience Initiative: 2017 Report of Activities, v. 1. Edited by N. Rogers. Geological Survey of Canada, Open File 8358, pp. 31-35. https://doi.org/10.4095/306402

Moran, P.C., Barr, S.M., White, C.E., and Hamilton, M.A. 2007. Petrology, age, and tectonic setting of the Seal Island Pluton, offshore southwestern Nova Scotia. Canadian Journal of Earth Sciences, 44, pp. 1467-1478. https://doi.org/10.1139/e07-023

O'Beirne, A.M. 1979. Geology of the Gillis Mountain Pluton, Cape Breton Island, Nova Scotia. Unpublished M.Sc. thesis, Acadia University, Wolfville, Nova Scotia, 168 p.

O'Beirne-Ryan, Barr, S.M. and Jamieson, R.A. 1986. Contrasting petrology and age of two megacrystic granitoid plutons, Cape Breton Island, Nova Scotia. In Current Research, Part B, Geological Survey of Canada, Paper 86-1B: pp. 179-190. https://doi. org/10.4095/120643

O’Neill, M. 1996. Geology of the Leonard MacLeod Brook area, southern Cape Breton Highlands, Nova Scotia. Unpublished M.Sc. thesis, Acadia University, Wolfville, Nova Scotia, $203 \mathrm{p}$.

Paton, C., Hellstrom, J.C., Paul, B., Woodhead, J.D., and Hergt, J.M. 2011. Iolite: Freeware for the visualisation and processing of mass spectrometric data. Journal of Analytical Atomic Spectrometry, 26, pp. 2508-2518. https://doi.org/10.1039/c1ja10172b

Petrus, J.A. and Kamber, B.S. 2012. VizualAge: a novel approach to laser ablation ICP-MS U- $\mathrm{Pb}$ geochronology data reduction. Geostandards and Geoanalytical Research, 36, pp. 247-270. https://doi. org/10.1111/j.1751-908X.2012.00158.x

Plint, H. E. and Jamieson, R. A. 1989. Microstructure, metamorphism and tectonics of the western Cape Breton Highlands, Nova Scotia. Journal of Metamorphic Geology, 7, pp. 407-424. https://doi. org/10.1111/j.1525-1314.1989.tb00606.x

Potter, J., Longstaffe, F.J., Barr, S.M., Thompson, M.D., and White, C.E. 2008a. Altering Avalonia: oxygen isotopes and terrane distinction. Canadian Journal of Earth Sciences, 45, pp. 815-825. https://doi.org/10.1139/ E08-024

Potter, J., Longstaffe, F.J., and Barr, S.M. 2008b. Regional ${ }^{18} \mathrm{O}$-depletion in Neoproterozoic igneous rocks of Avalonia, Cape Breton Island and southern New Brunswick, Canada. Geological Society of America Bulletin, 120, pp. 347-367. https://doi.org/10.1130/ B26191.1
Price, J., Barr, S.M., Raeside, R.P. and Reynolds, P. 1999. Petrology, tectonic setting, and $40 \mathrm{Ar} / 39 \mathrm{Ar}$ (hornblende) dating of the Late Ordovician-Early Silurian Belle Cote Road orthogneiss, western Cape Breton Highlands, Nova Scotia; Atlantic Geology, 35, pp. 1-17. https://doi.org/10.4138/2021

Raeside, R.P. and Barr, S.M. 1990. Geology and tectonic development of the Bras d'Or suspect terrane, Cape Breton Island, Nova Scotia. Canadian Journal of Earth Sciences, 27, pp. 1317-1381. https://doi.org/10.1139/ e90-147

Raeside, R.P. and Barr, S.M. 1992. Preliminary report on the geology of the northern and eastern Cape Breton Highlands, Nova Scotia. Geological Survey of Canada Paper 89-14. 39 p. https://doi.org/10.4095/134060

Reynolds, P.H., Jamieson, R.A., Barr, S.M., and Raeside, R.P. 1989. $\mathrm{A}{ }^{40} \mathrm{Ar} /{ }^{39} \mathrm{Ar}$ dating study in the Cape Breton Highlands, Nova Scotia: thermal histories and tectonic implications. Canadian Journal of Earth Sciences, 26, pp. 2081-2091. https://doi.org/10.1139/e89-175

Rogers, N., van Staal, C.R., McNicoll, V., Pollock, J., Zagorevski, A., and Whalen, J. 2006. Neoproterozoic and Cambrian arc magmatism along the eastern margin of the Victoria Lake Supergroup: a remnant of Ganderian basement in central Newfoundland? Precambrian Research, 147, pp. 320-341. https://doi. org/10.1016/j.precamres.2006.01.025

Sangster, D.F. and Vaillancourt, P.D. 1990. Geology of the Yava sandstone-lead deposit, Cape Breton Island, Nova Scotia, Canada. In Mineral Deposit Studies in Nova Scotia, v. 1. Edited by A.L. Sangster, Geological Survey of Canada Paper 90-8, pp. 203-244.

Schofield, D.I., Potter, J., Barr, S.M., Horák, J.M., Millar, I.L., and Longstaffe, F.J. 2016. Reappraising the Neoproterozoic 'East Avalonian' terranes of southern Great Britain: Ganderia not Avalonia? Gondwana Research, 35, pp. 257-271. https://doi.org/10.1016/j. gr.2015.06.001

Sheard, E.R. 2007. Geology, mineralisation and alteration of the Deep Cove porphyry $\mathrm{Cu}-\mathrm{Mo}$ deposit, Cape Breton Island, Nova Scotia. Unpublished B.Sc. thesis, University of St. Andrews, Fife, Scotland, 129 p.

Slaman, L.R., Barr, S.M., White, C.E., and van Rooyen, D. 2017. Age and tectonic setting of granitoid plutons in the Chéticamp belt, western Cape Breton Island, Nova Scotia, Canada. Canadian Journal of Earth Sciences. Canadian Journal of Earth Sciences, 54, pp. 88-109. https://doi.org/10.1139/cjes-2016-0073

Van Rooyen, D., Barr, S.M. and White, C.E. 2017. Proterozoic to Cambrian zircon geochronology in the Bras d'Or terrane on Cape Breton Island, Nova Scotia: deciphering the infrastructure of Ganderia. Atlantic Geology, 53, p. 179.

Van Staal, C.R. 2007. Pre-Carboniferous metallogeny of the Canadian Appalachians. In Mineral Deposits of Canada: a Synthesis of Major Deposit Types, District 
Metallogeny, the Evolution of Geological Provinces, and Exploration Methods. Edited by W.D. Goodfellow. Mineral Deposits Division, Geological Association of Canada, Special Publication, 5, pp. 793-818.

Van Staal, C.R. and Barr, S.M. 2012. Lithospheric architecture and tectonic evolution of the Canadian Appalachians. In Tectonic Styles in Canada Revisited: the LITHOPROBE perspective. Edited by J.A. Percival, F.A. Cook, and R.M. Clowes. Geological Association of Canada Special Paper, 49: 41-95.

Van Staal, C.R., Sullivan, R.W., and Whalen, J.B. 1996. Provenance and tectonic history of the Gander Margin in the Caledonian/Appalachian Orogen: implications for the origin and assembly of Avalonia. In Avalonian and related peri-Gondwanan terranes of the circumNorth Atlantic. Edited by R.D. Nance and M.D. Thompson. Geological Society of America Special Paper 304, pp. 347-367.

Waldron, J.W.F, Barr, S.M., Park, A.F., White, C.E., and Hibbard, J. P. 2015. Late Paleozoic strike-slip faults in Maritime Canada and their role in the reconfiguration of the northern Appalachian orogen. Tectonics, 34, pp. 1-24. https://doi.org/10.1002/2015TC003882

White, C.E. and Barr, S.M. 1998. Stratigraphy and tectonic significance of the Lower to Middle Devonian McAdams Lake Formation, Cape Breton Island, Nova Scotia. Atlantic Geology, 34, pp. 133-145. https://doi. org/10.4138/2044

White, C.E., Barr, S.M., Bevier, M.L., and Kamo, S. 1994. A revised interpretation of Cambrian and Ordovician rocks in the Bourinot belt of central Cape Breton Island, Nova Scotia. Atlantic Geology, 30, pp. 123-142. https://doi.org/10.4138/2125

White, C.E., Barr, S.M., and Ketchum, J.W.F. 2003. New age controls on rock units in pre- Carboniferous basement blocks in southwestern Cape Breton Island and adjacent mainland Nova Scotia. In Report of Activities 2002. Edited by D.R. MacDonald. Nova Scotia Department of Natural Resources, Minerals and Energy Branch, Report ME 2003-1, pp. 163-178.

White, C.E., Barr, S.M., Davis, D.W., Swanton, D.S., Ketchum, J.W.F., and Reynolds, P.H. 2016. Field relations, age, and tectonic setting of metamorphic and plutonic rocks in the Creignish Hills - North Mountain area, southwestern Cape Breton Island, Nova Scotia, Canada. Atlantic Geology, 52, pp. 35-57. https://doi. org/10.4138/atlgeol.2016.003
White, C. E., Shute, J., Sombini dos Santos, G., Barr, S. M., and van Rooyen, D. 2017. Progress report on geological and geochronological studies in the Cheticamp area, Aspy terrane, Cape Breton Island, Nova Scotia. In Geoscience and Mines Branch, Report of Activities 2016-17. Nova Scotia Department of Natural Resources, Report ME 2017-001, pp. 89-93.

Wiebe, R.A. 1975. Origin and emplacement of Acadian granitic rocks, northern Cape Breton Island. Canadian Journal of Earth Sciences, 12, pp. 252-262. https://doi. org/10.1139/e75-022

Williams, H. 1978. Tectonic lithofacies map of the Appalachians. Memorial University Map No. 1, Department of Geology, Memorial University of Newfoundland, St. John's, Newfoundland,1:1 000000.

Willner, A.P., Barr, S.M., Gerdes, A., Massonne, H.-J., and White, C.E. 2013. Origin and evolution of Avalonia: evidence from $\mathrm{U}-\mathrm{Pb}$ and $\mathrm{Lu}-\mathrm{Hf}$ isotopes in zircon from the Mira terrane, Canada, and the Stavelot-Venn Massif, Belgium. Journal of the Geological Society, London, 170, pp. 769-784. https://doi.org/10.1144/ jgs 2012-152

Yaowanoiyothin, W. and Barr, S.M. 1991. Petrology of the Black Brook Granitic Suite, Cape Breton Island, Nova Scotia. Canadian Mineralogist, 29, pp. 499-515.

Zagorevski, A., Van Staal, C.R., McNicoll, V., and Rogers, N. 2007. Upper Cambrian to Upper Ordovician peri-Gondwanan island arc activity in the Victoria Lake Supergroup, Central Newfoundland: Tectonic development of the northern Ganderian margin. American Journal of Science, 307, pp. 339-370. https:// doi.org/10.2475/02.2007.02

Zagorevski, A., van Staal, C.R., Rogers, N., McNicoll, V., Dunning, G.R., and Pollock, J.C. 2010. Middle Cambrian to Ordovician arc-backarc development on the leading edge of Ganderia, Newfoundland Appalachians. In From Rodinia to Pangea: The lithotectonic record of the Appalachian region. Edited by R.P. Tollo, M.J. Batholomew, J.P. Hibbard, and P.M. Karabinos. Geological Society of America Memoir, 206, pp. 367-396. https://doi.org/10.1130/2010.1206(16)

Editorial responsibility: David P. West, Jr. 


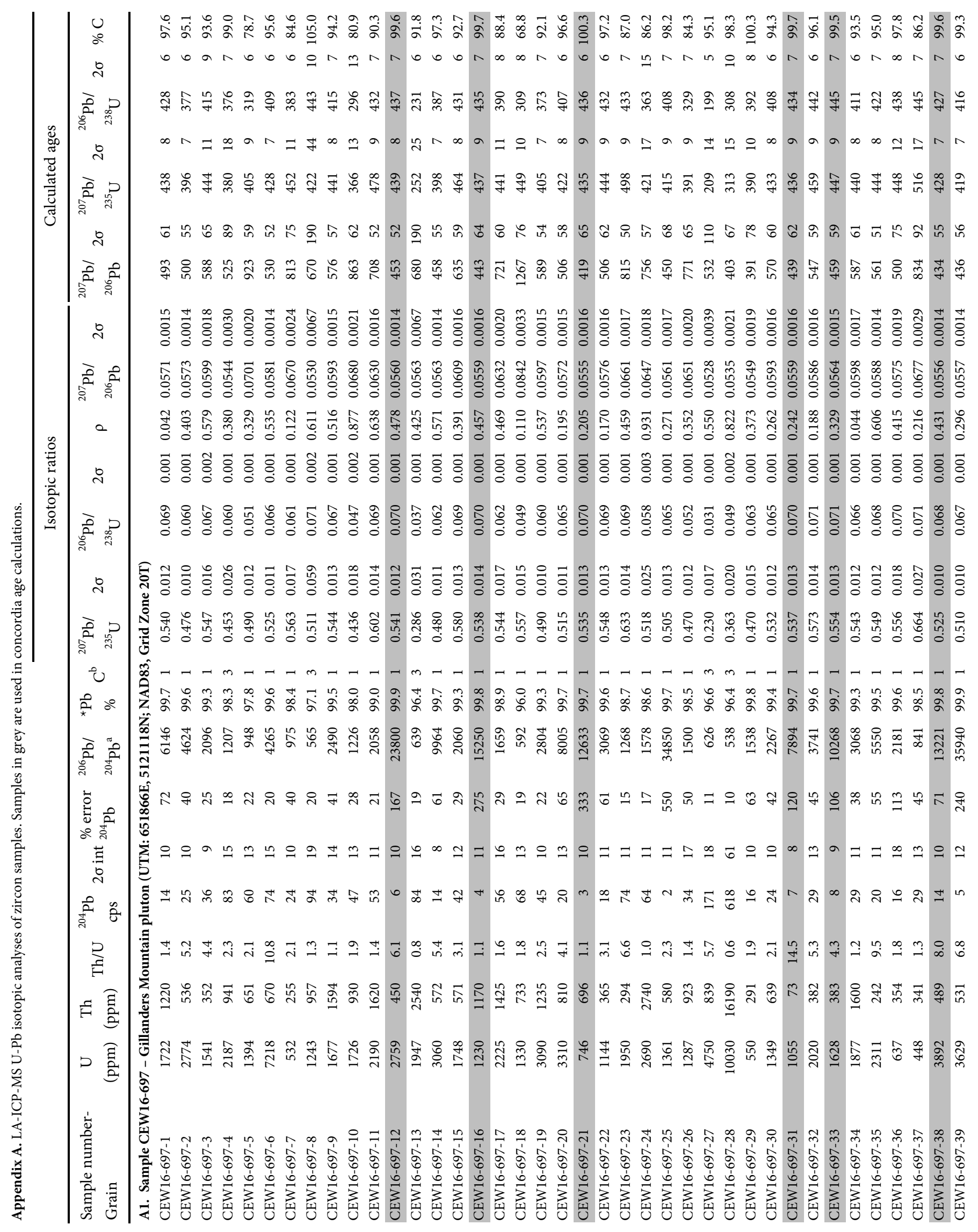




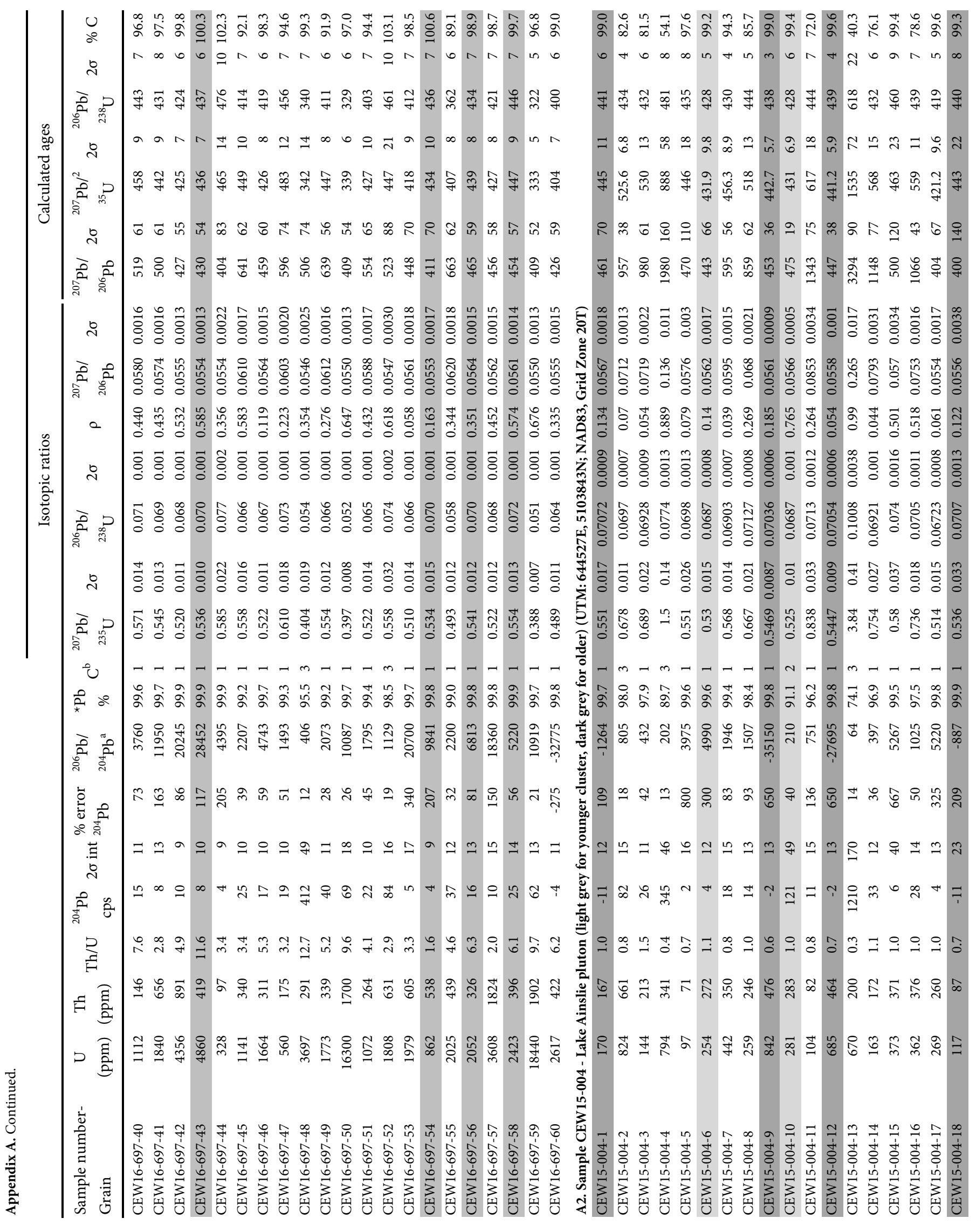




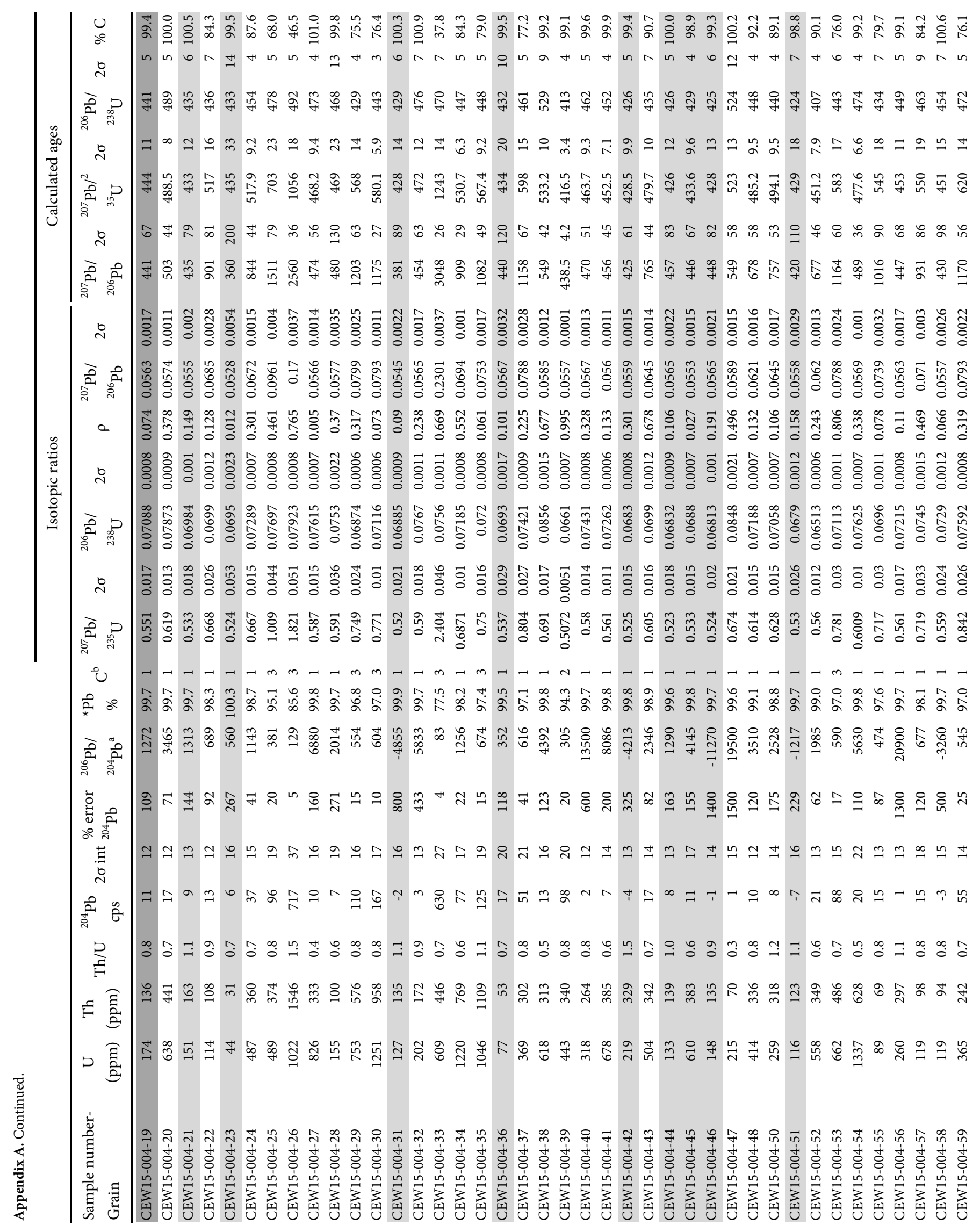




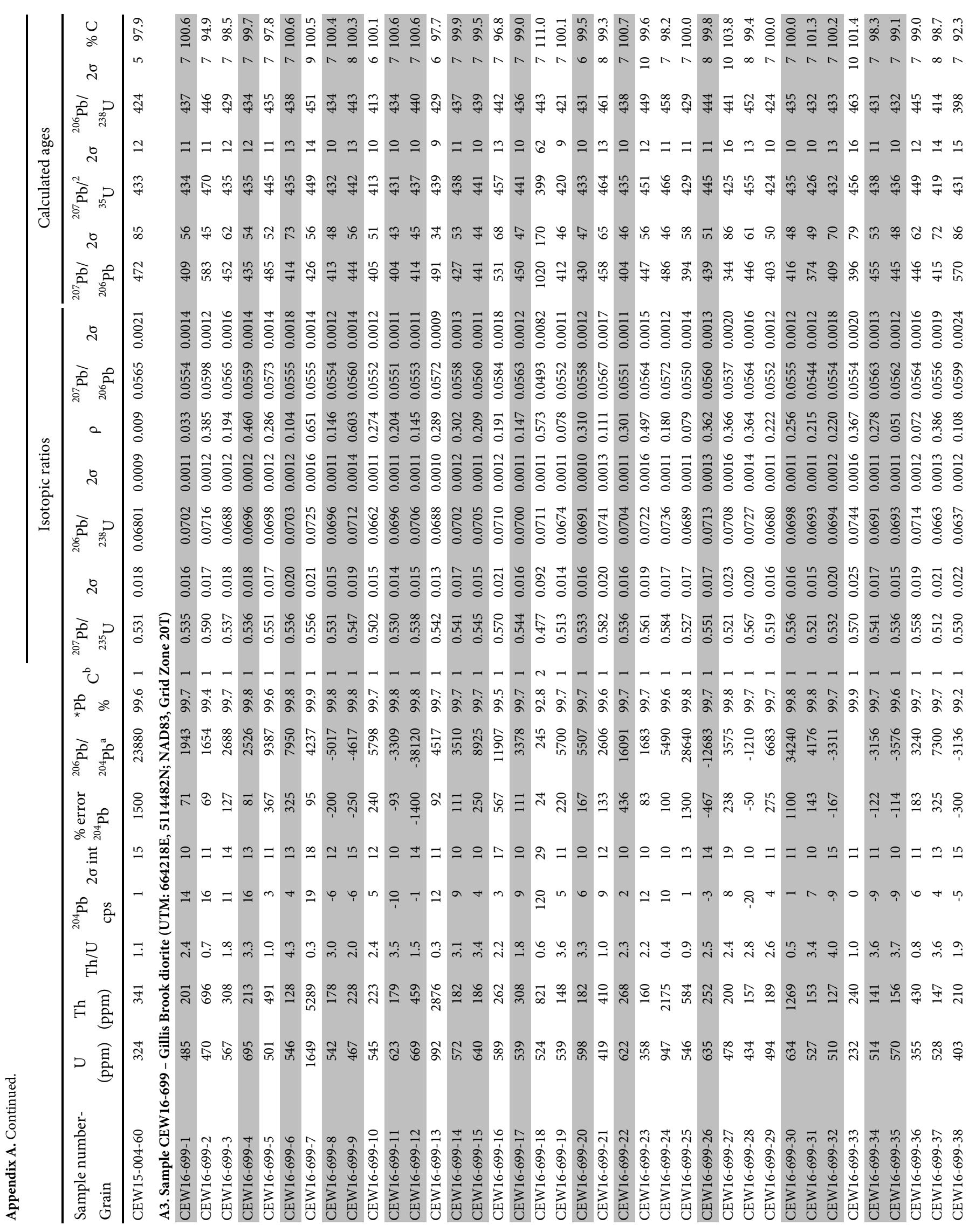




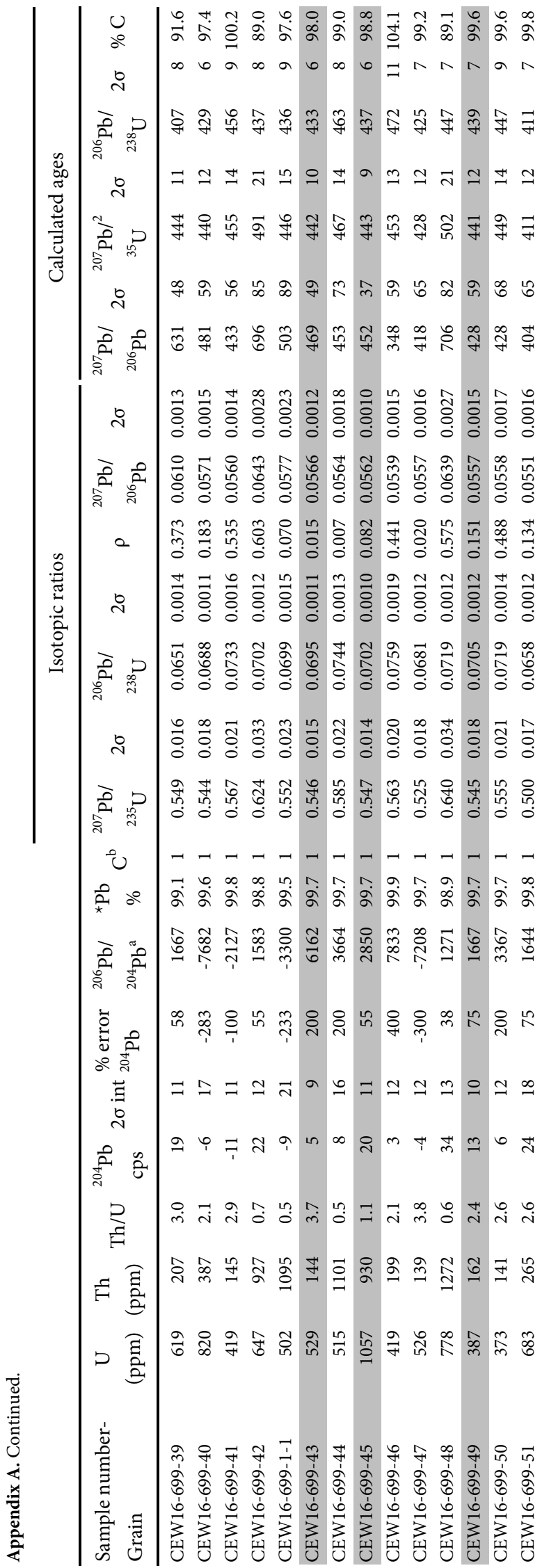

응

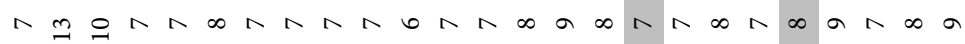

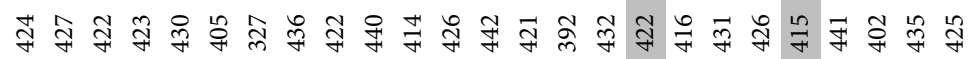

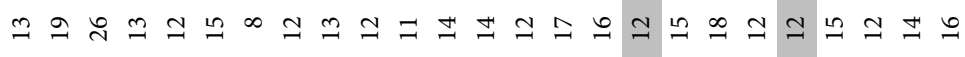

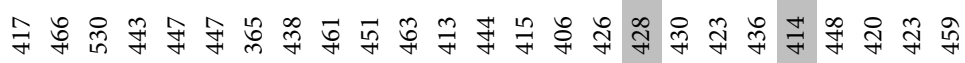

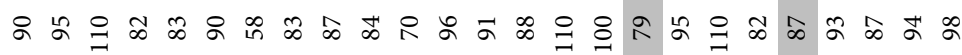

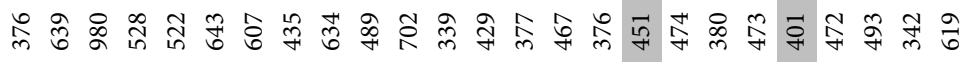

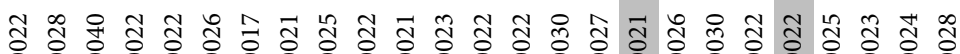

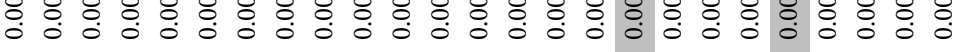

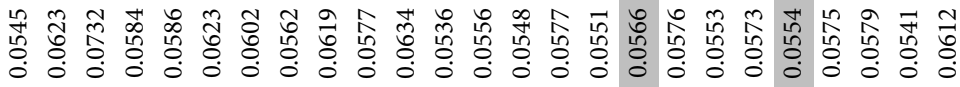

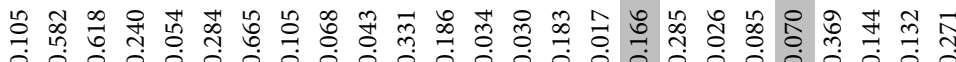

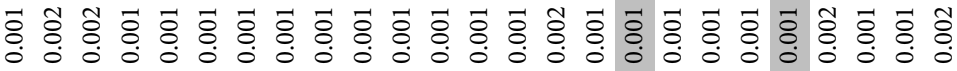

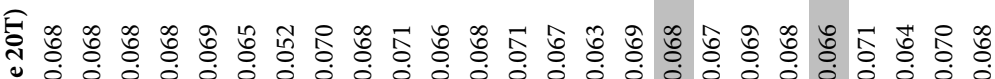
งั้

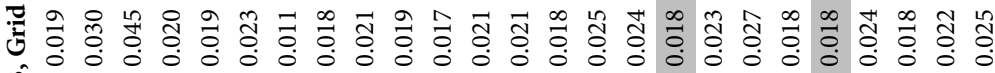

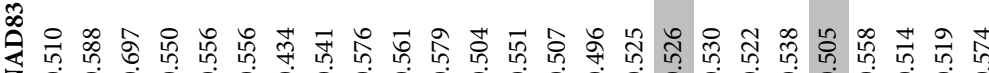
ż

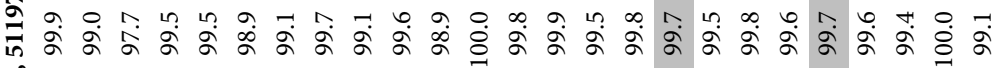

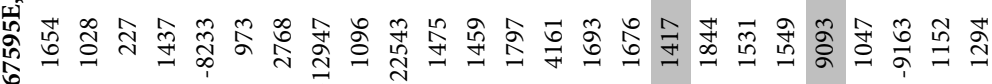

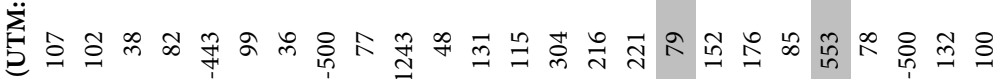

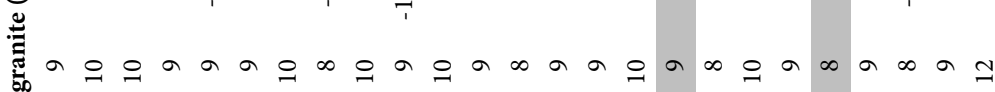

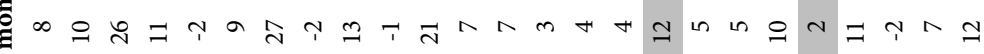

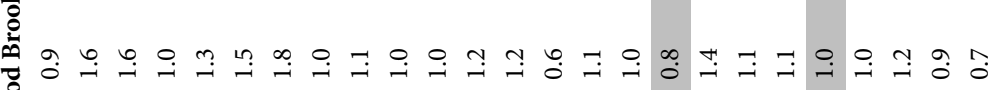

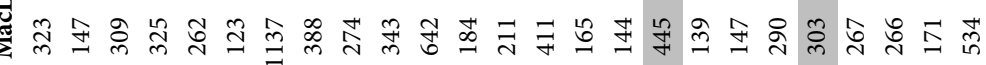
햄

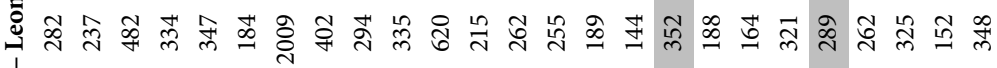

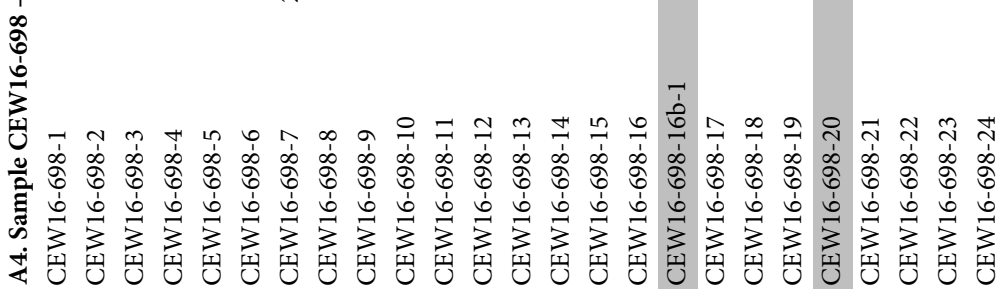




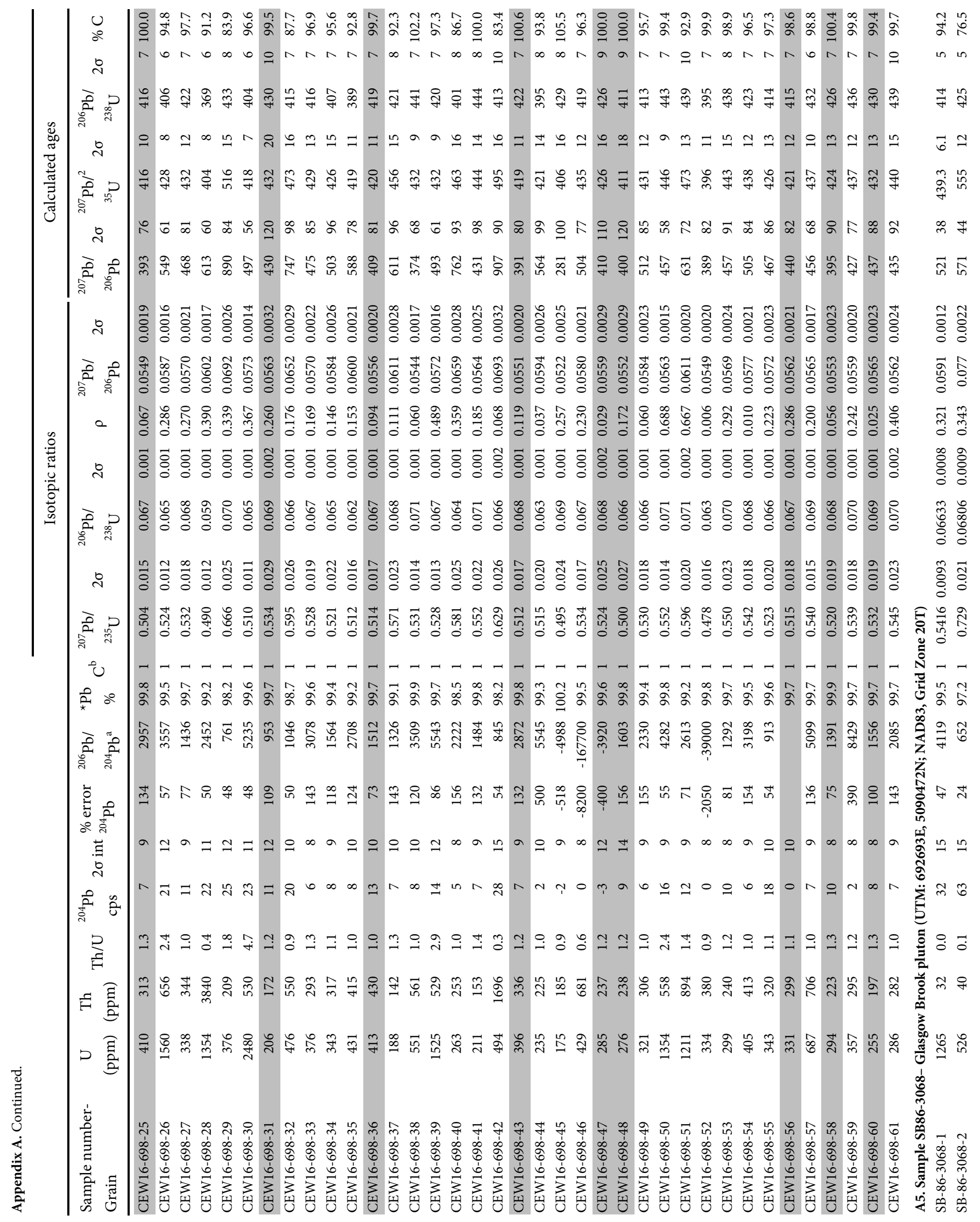




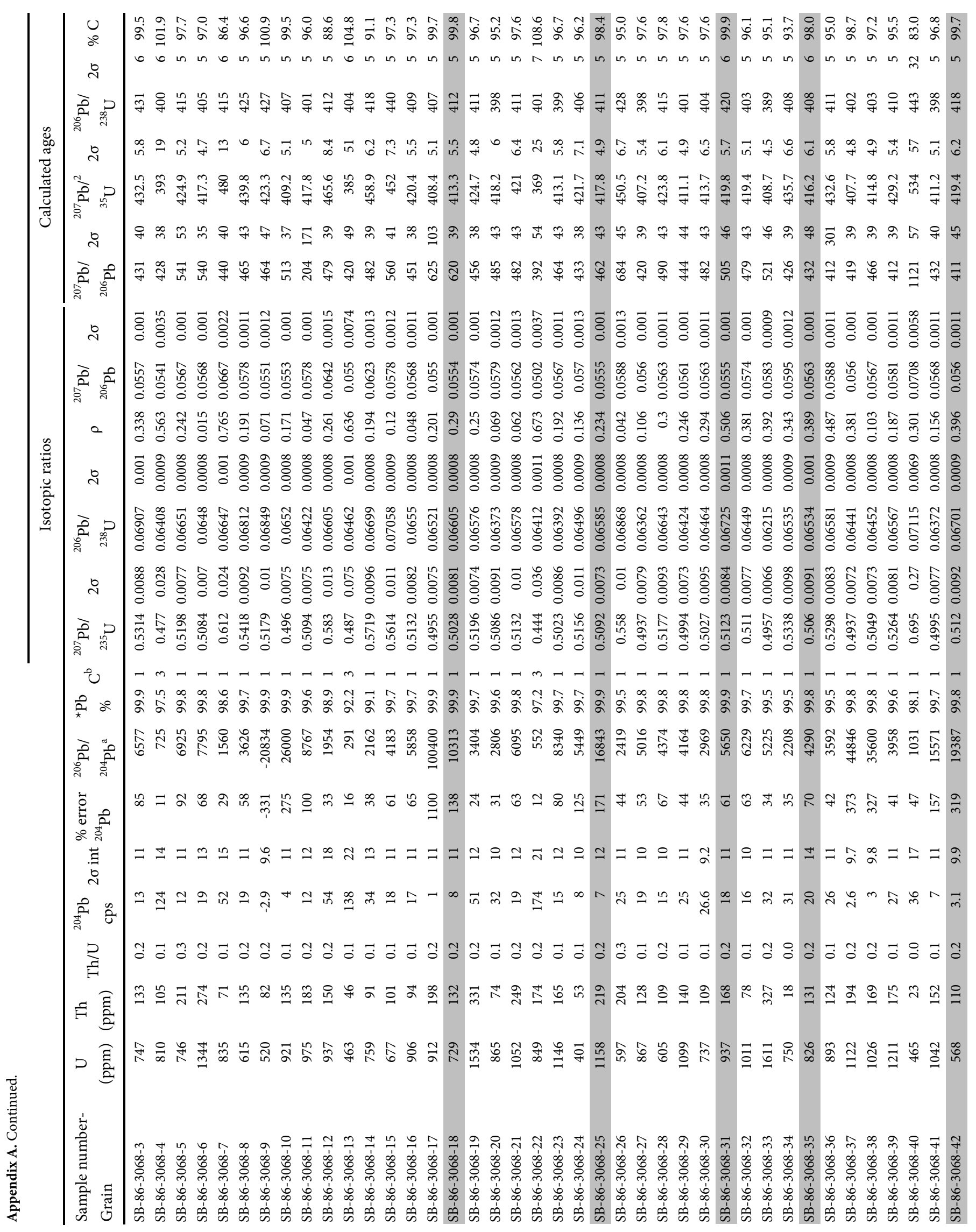




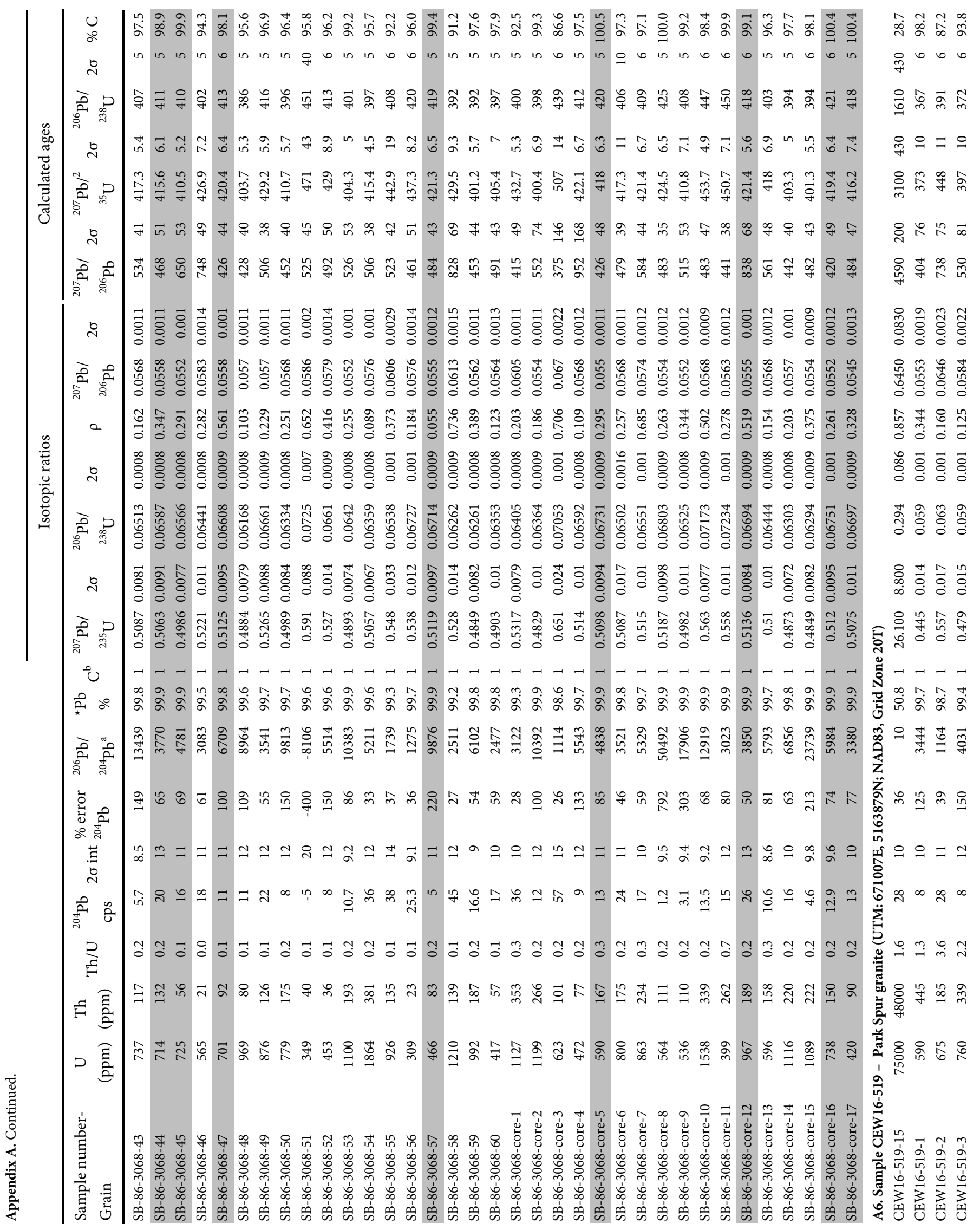




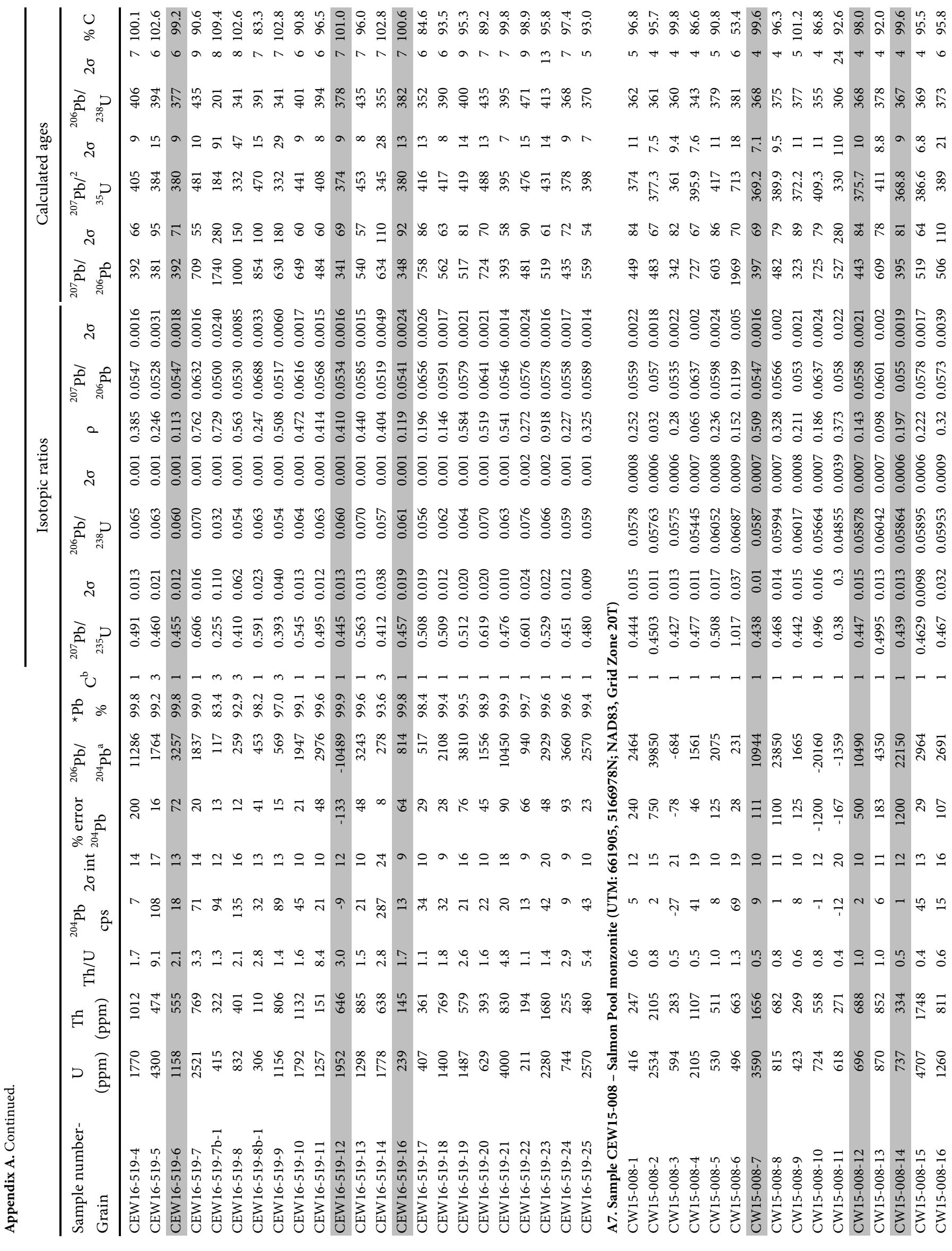




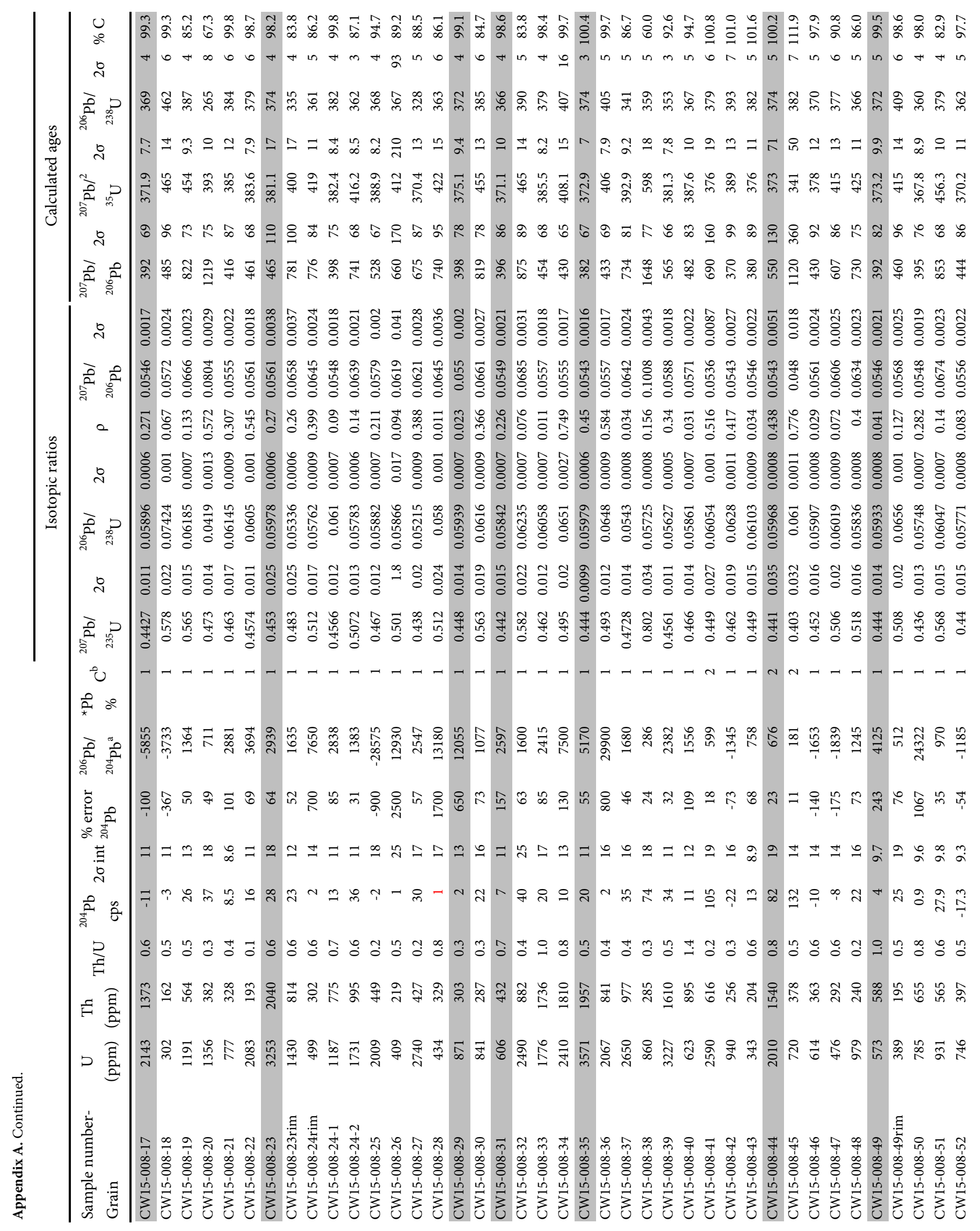




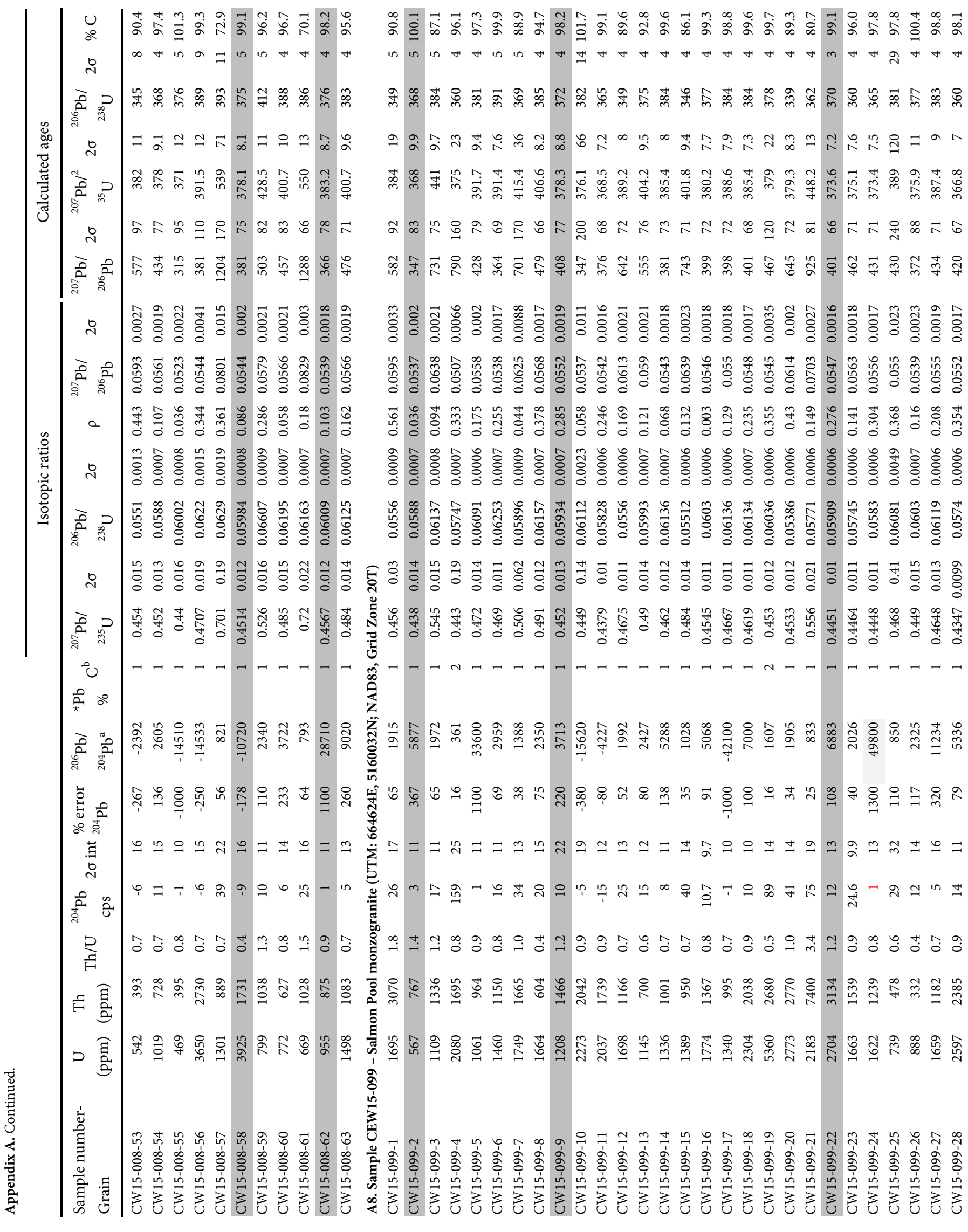




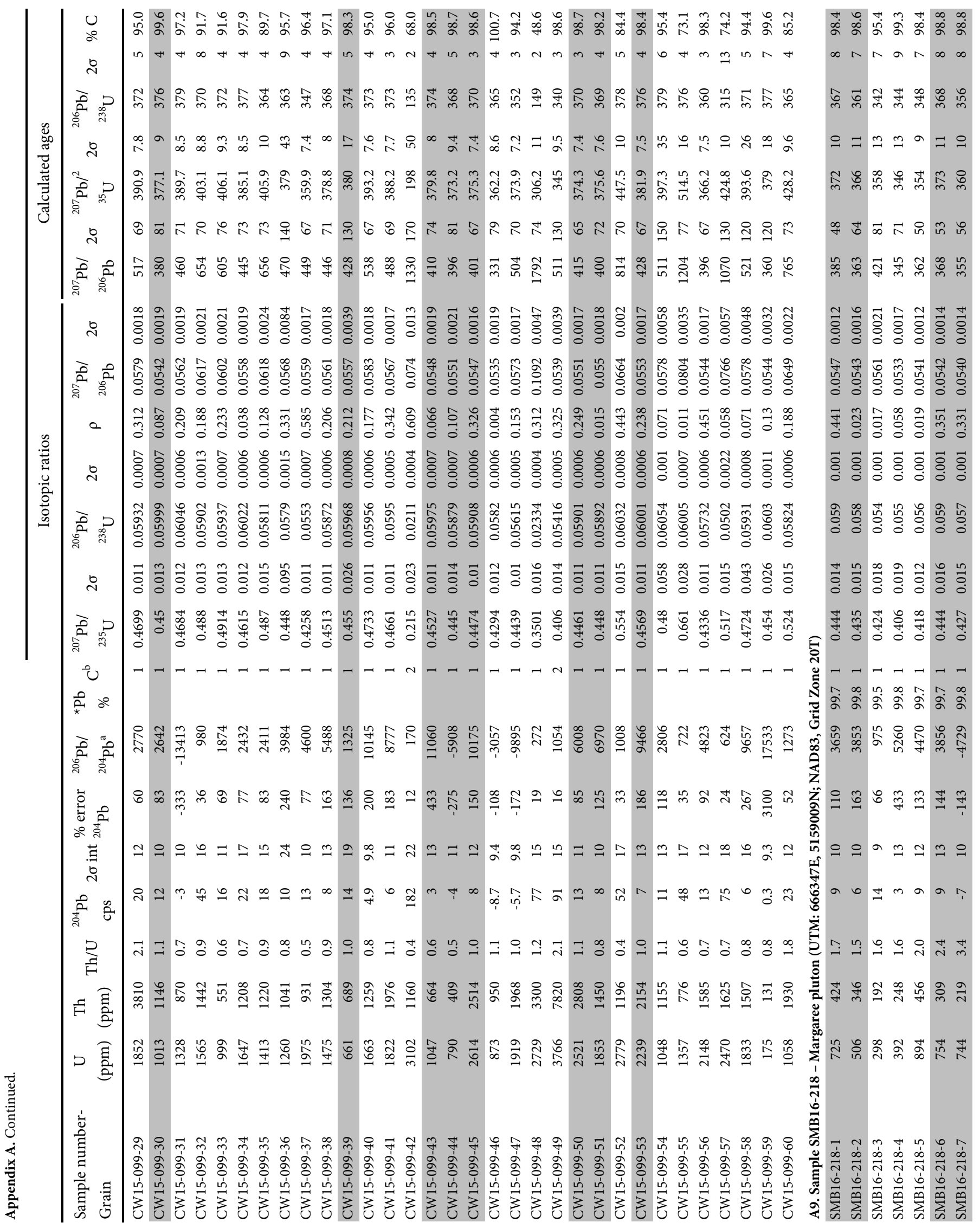




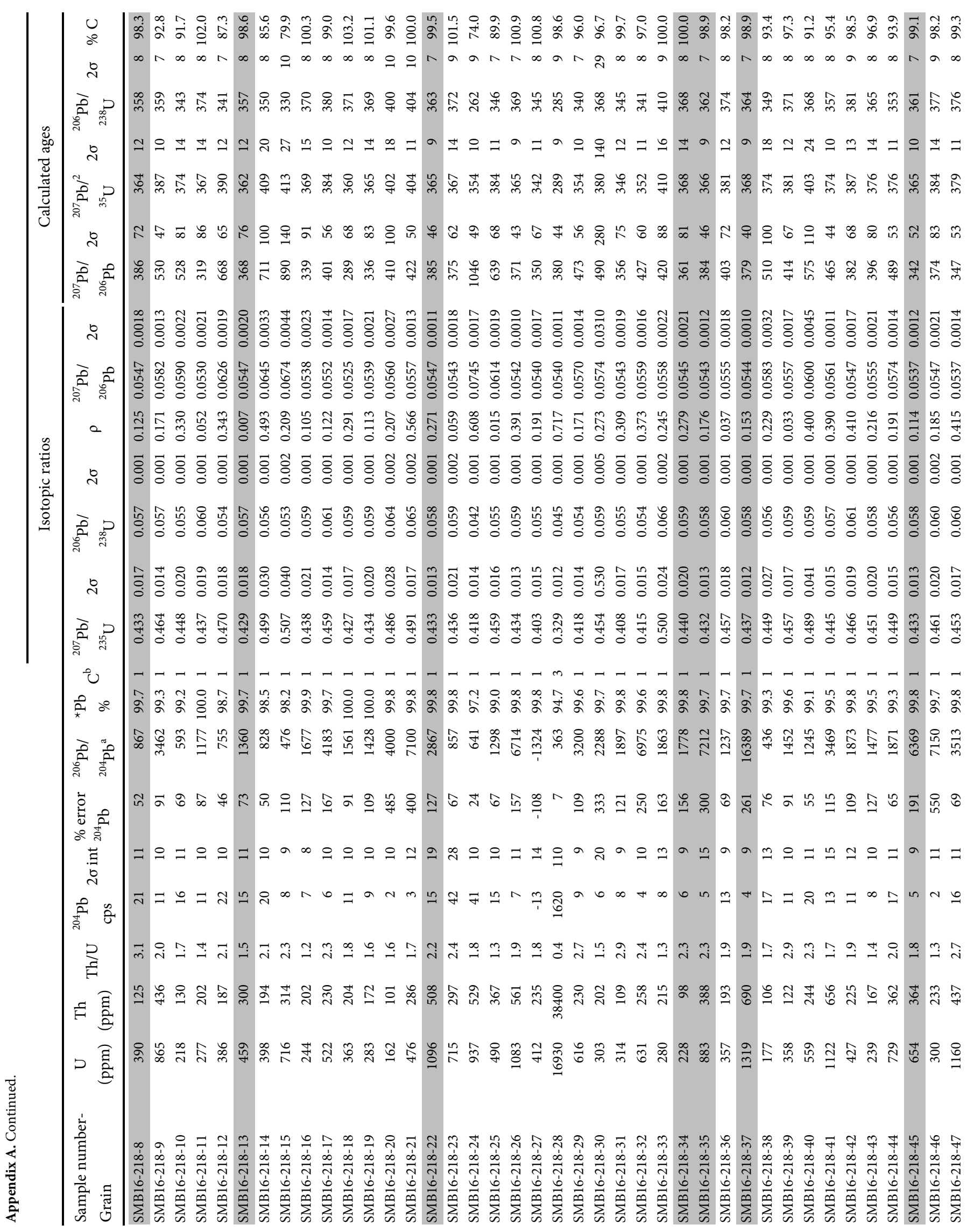




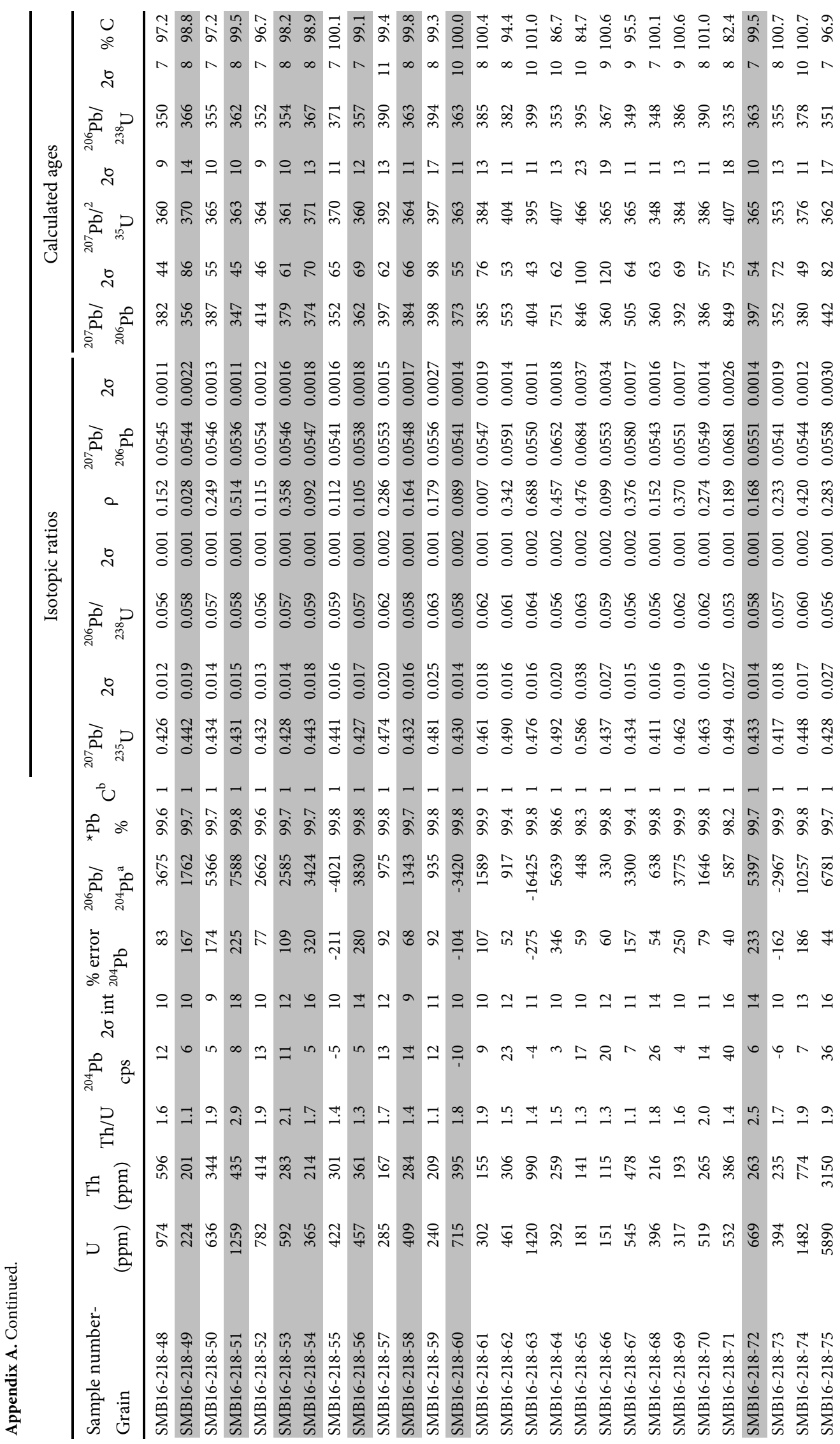

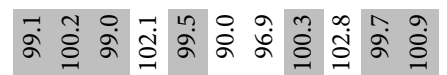

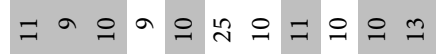

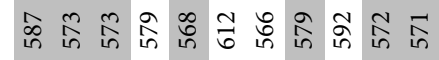

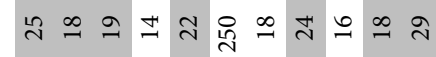

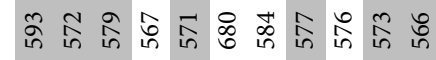

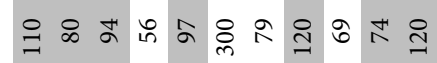

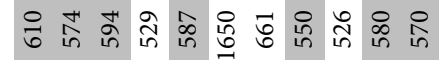

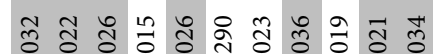
:

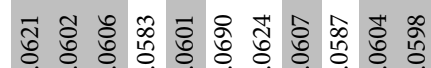

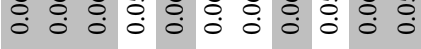

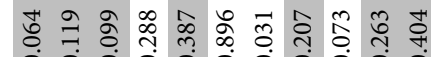

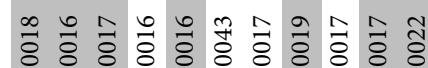
영

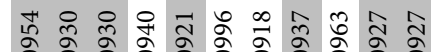
영

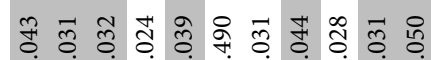

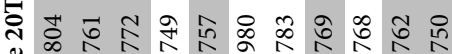
궁

व

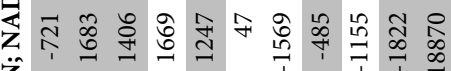
每

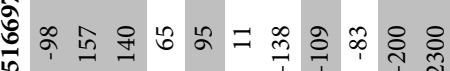
蛄の .

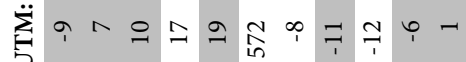
递

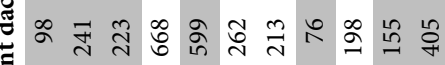
党

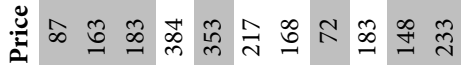
สี $\stackrel{\circ}{\circ}$ 至 政

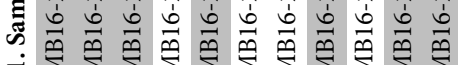

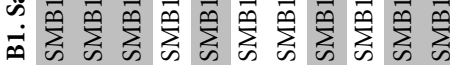




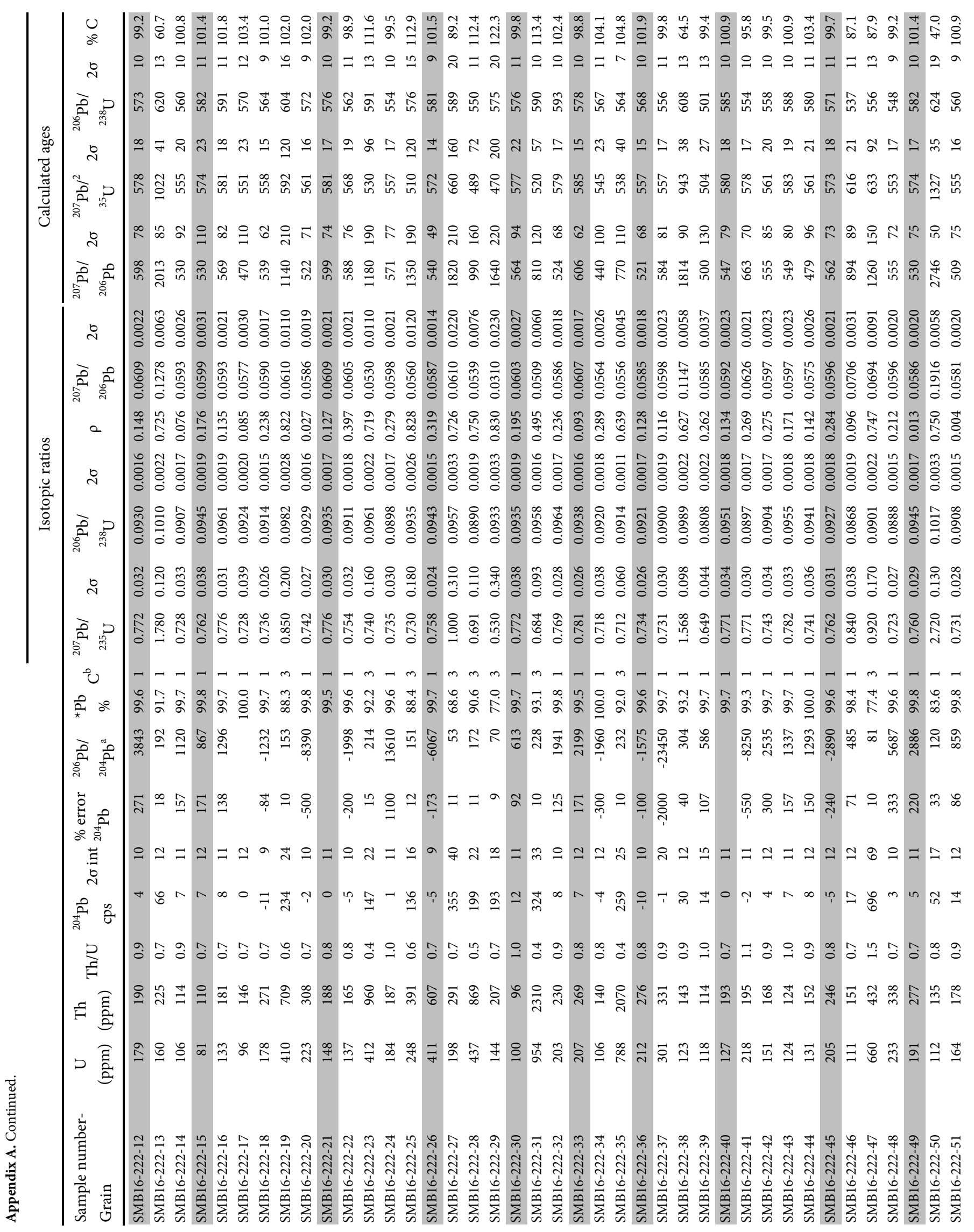




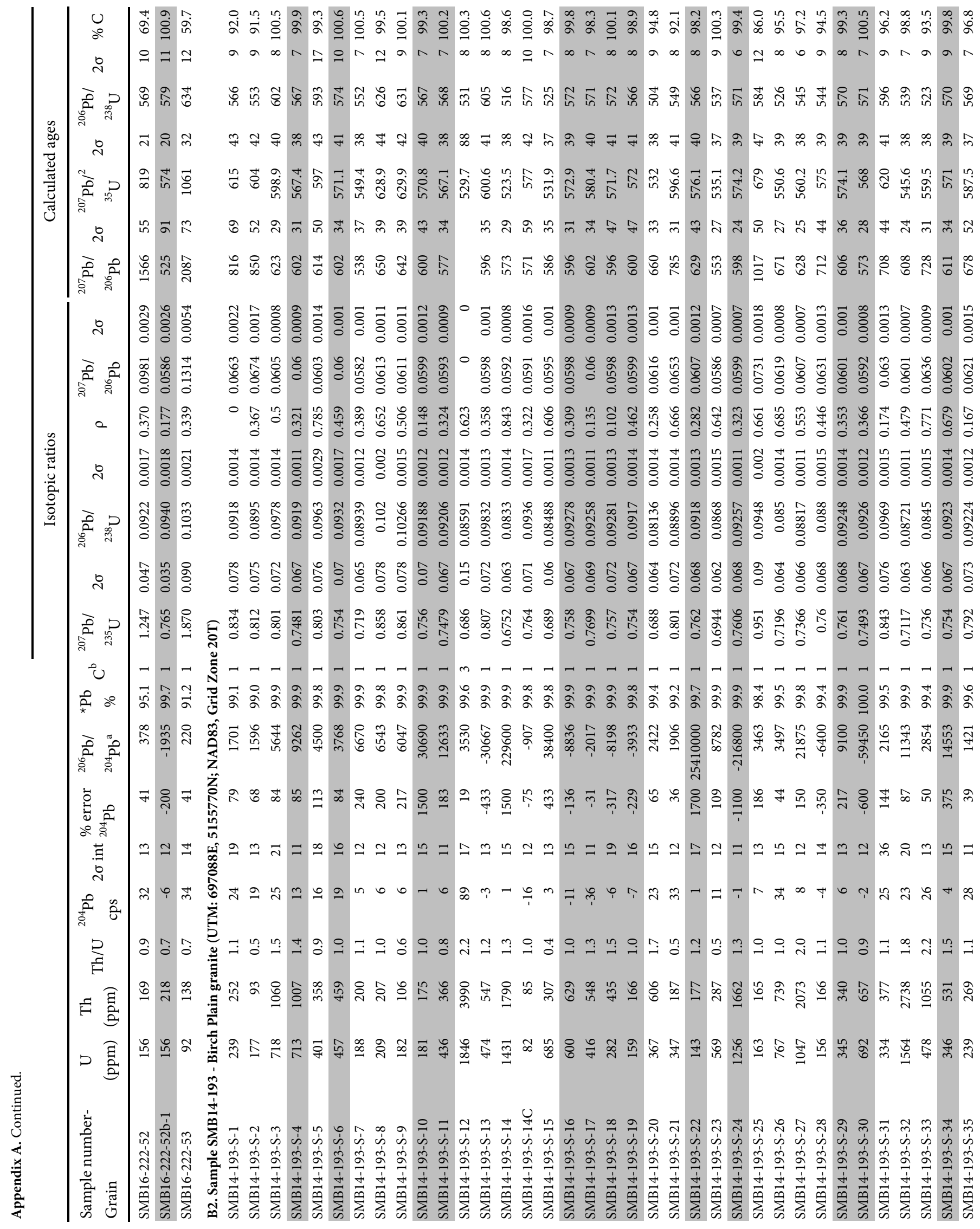




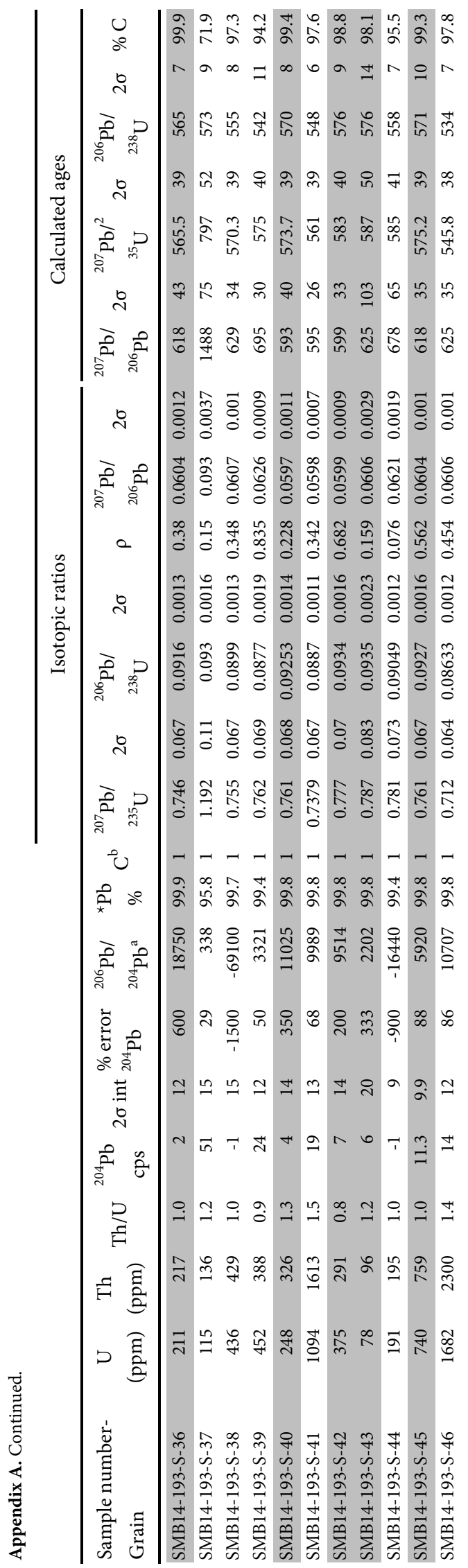

क⿺辶大

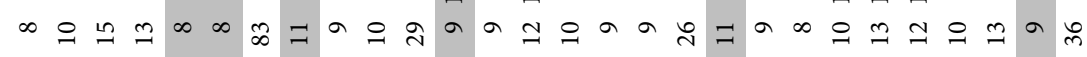

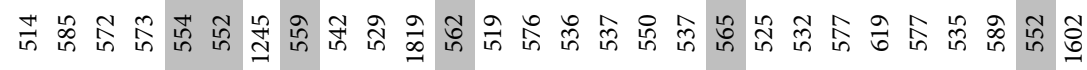

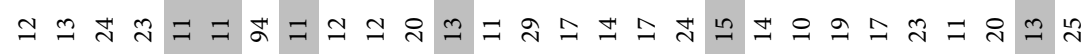

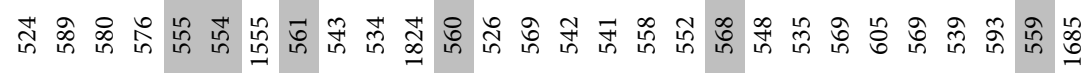

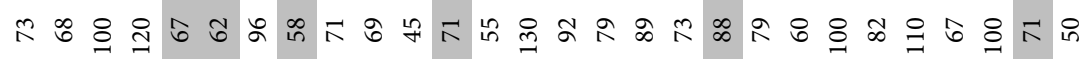

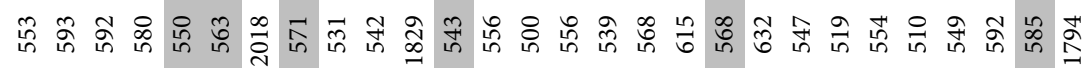

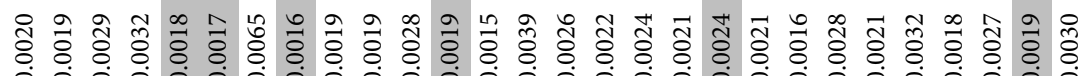

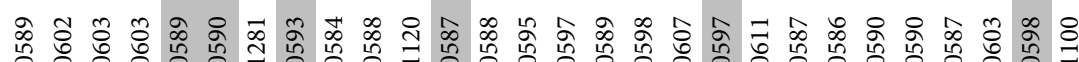

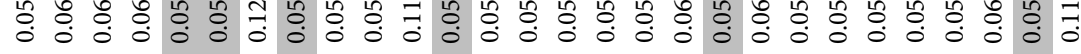

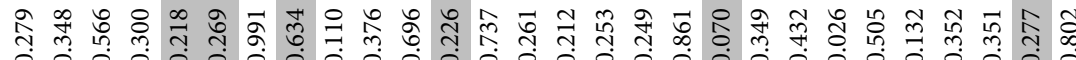

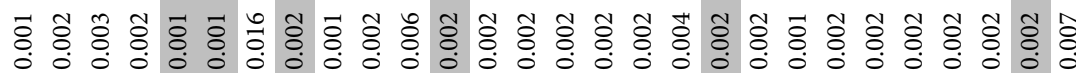

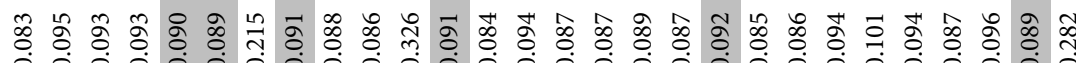

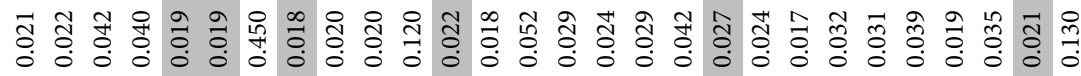

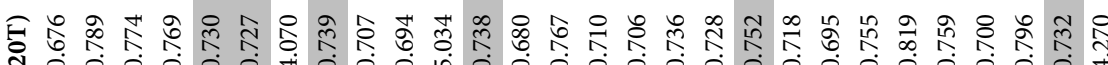
范 产 要

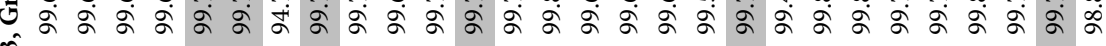

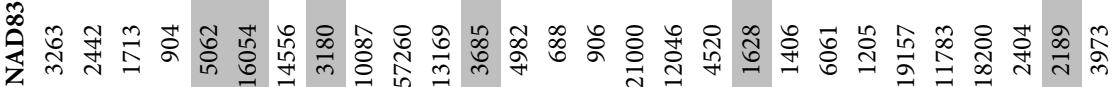

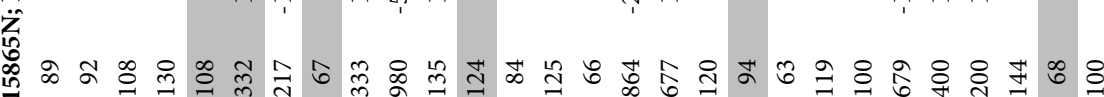

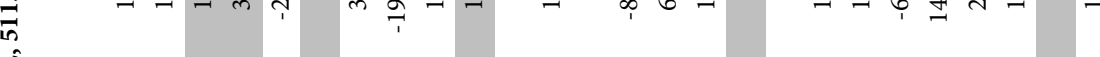

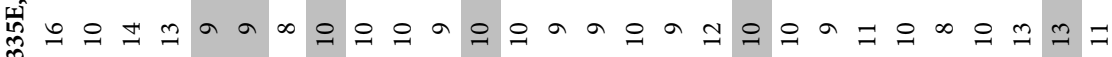
:

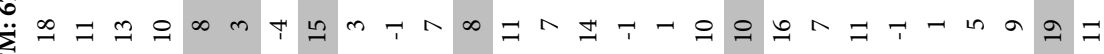

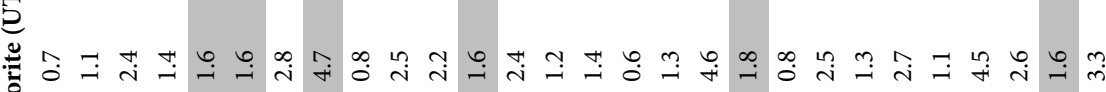

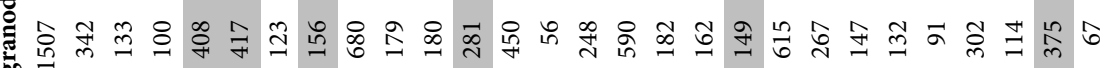
要 $\begin{array}{llll} & \\ 0\end{array}$ 


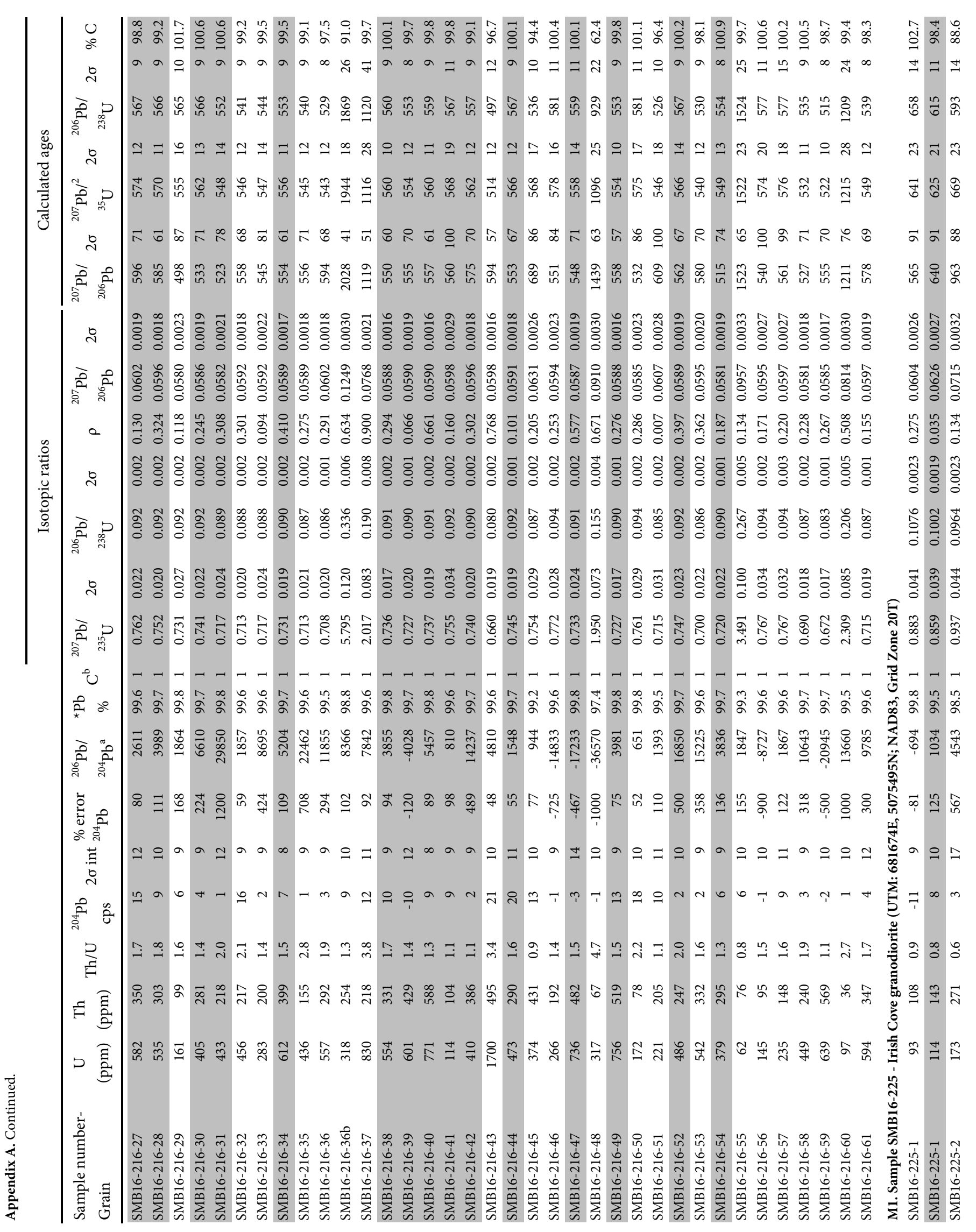




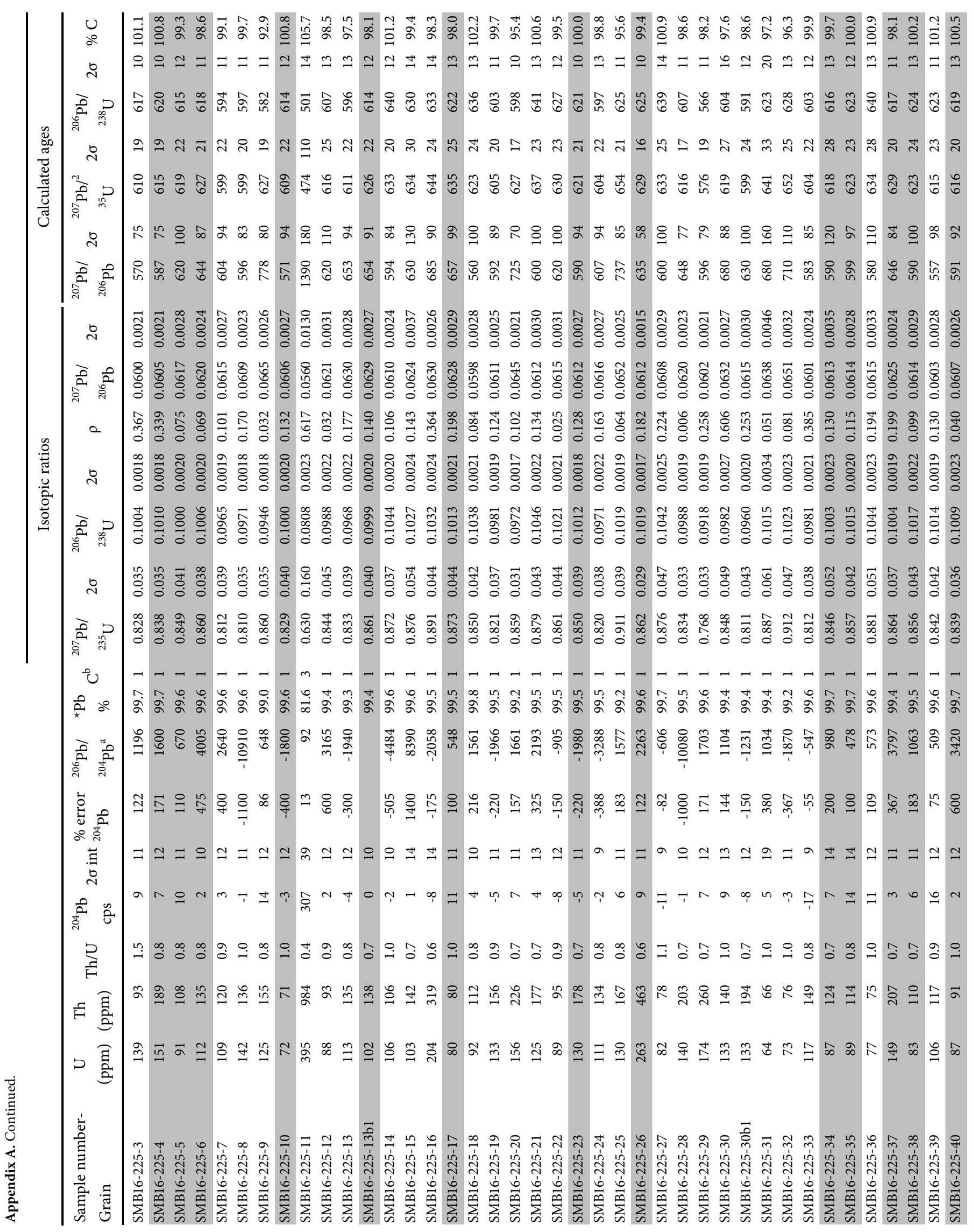




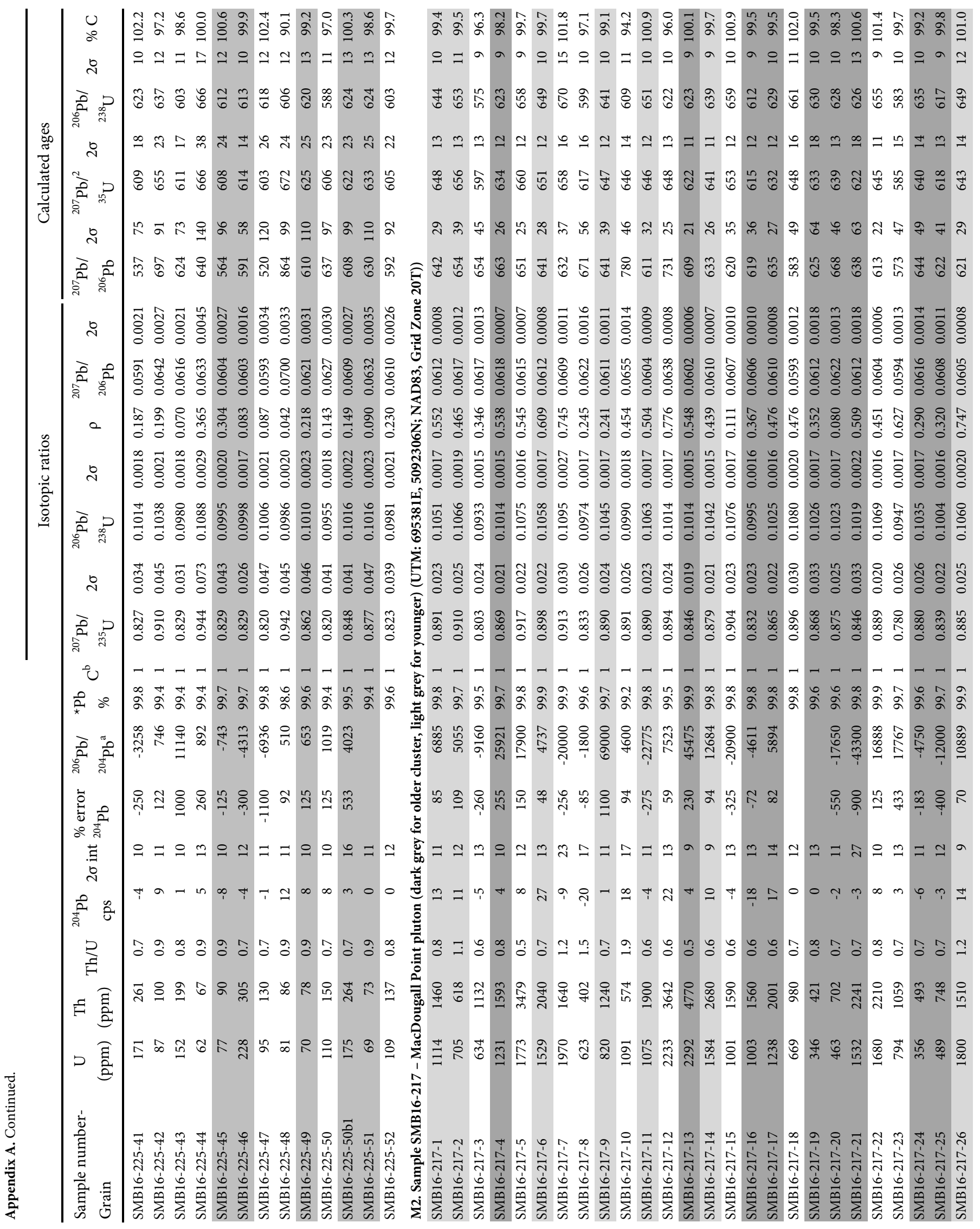




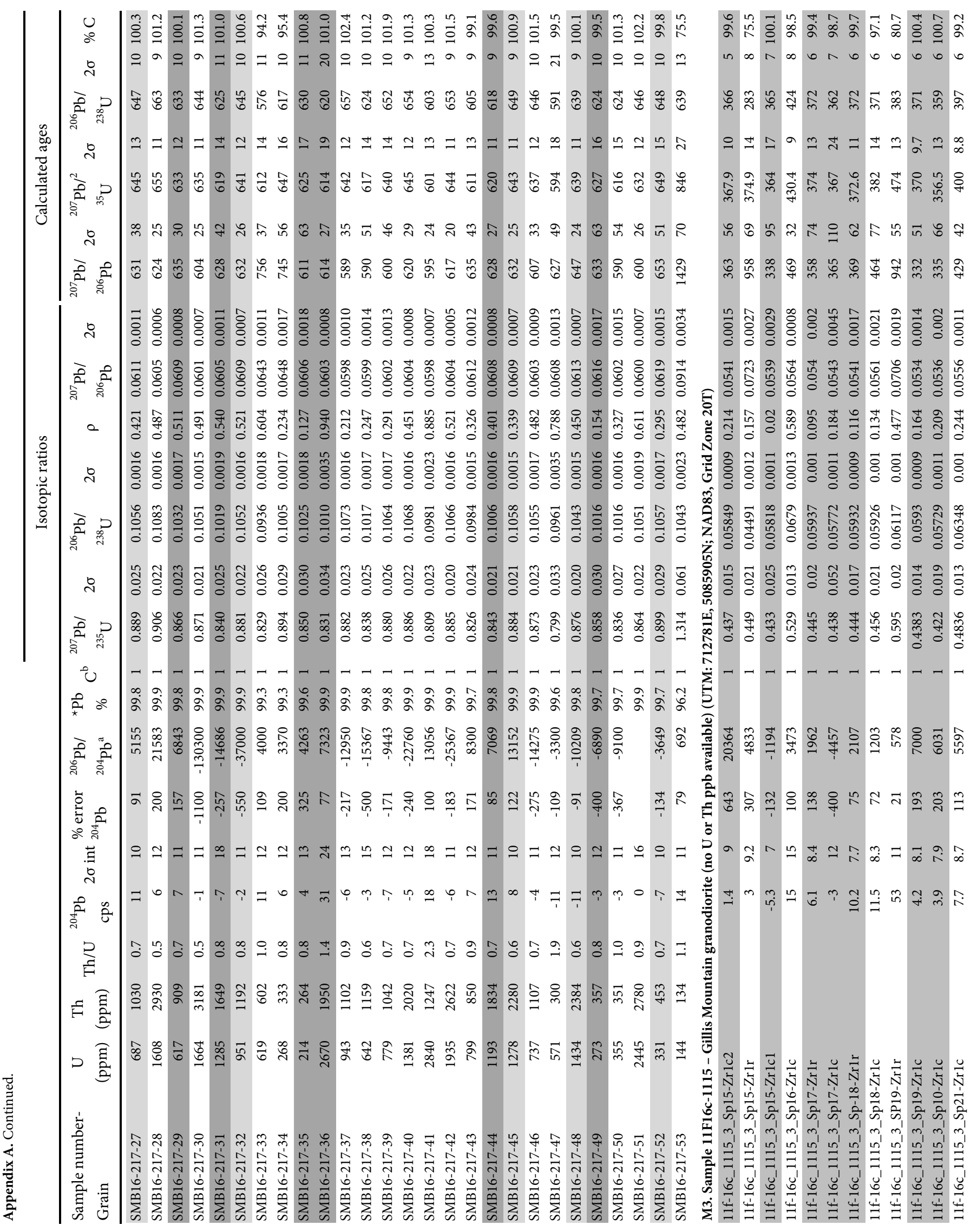




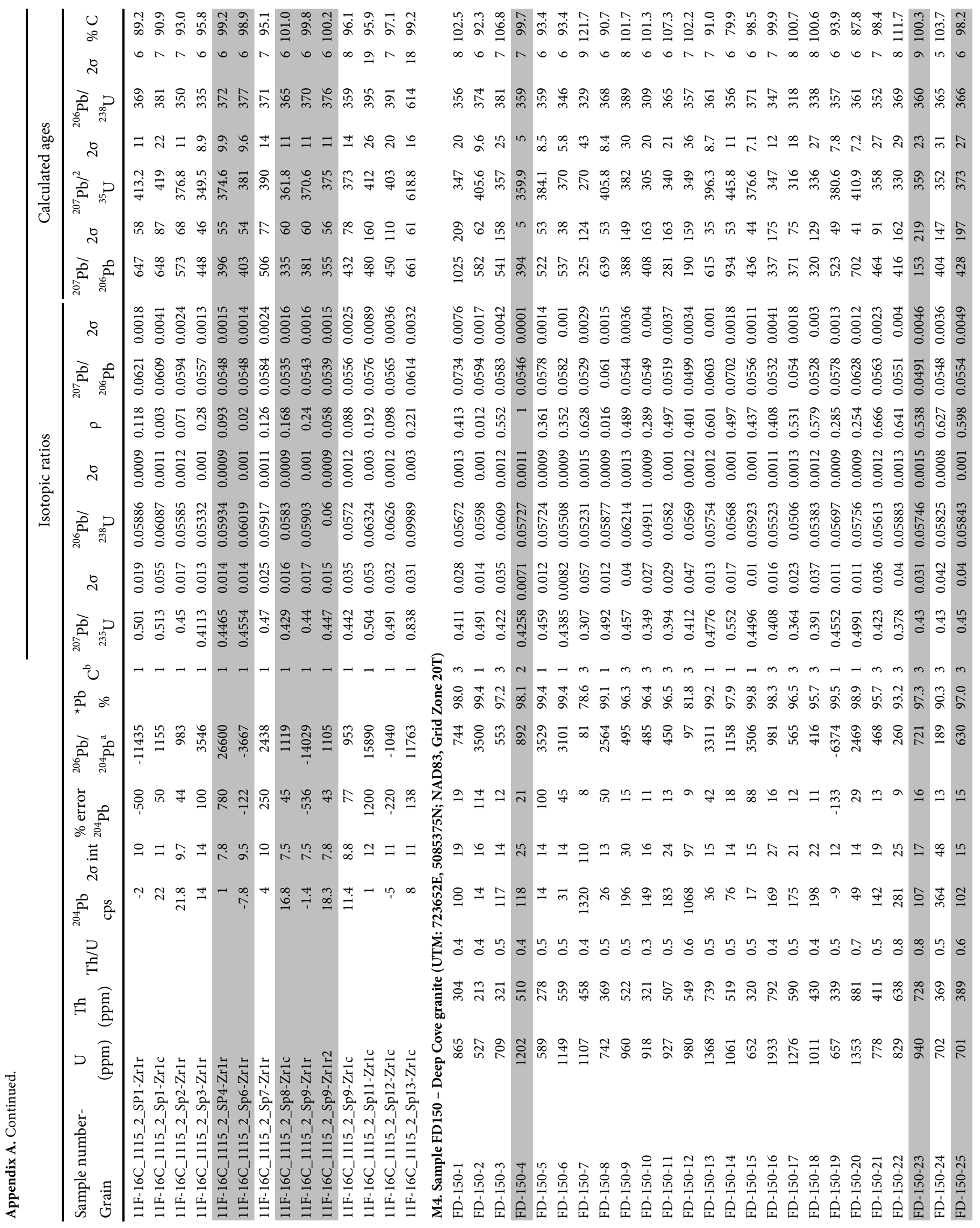




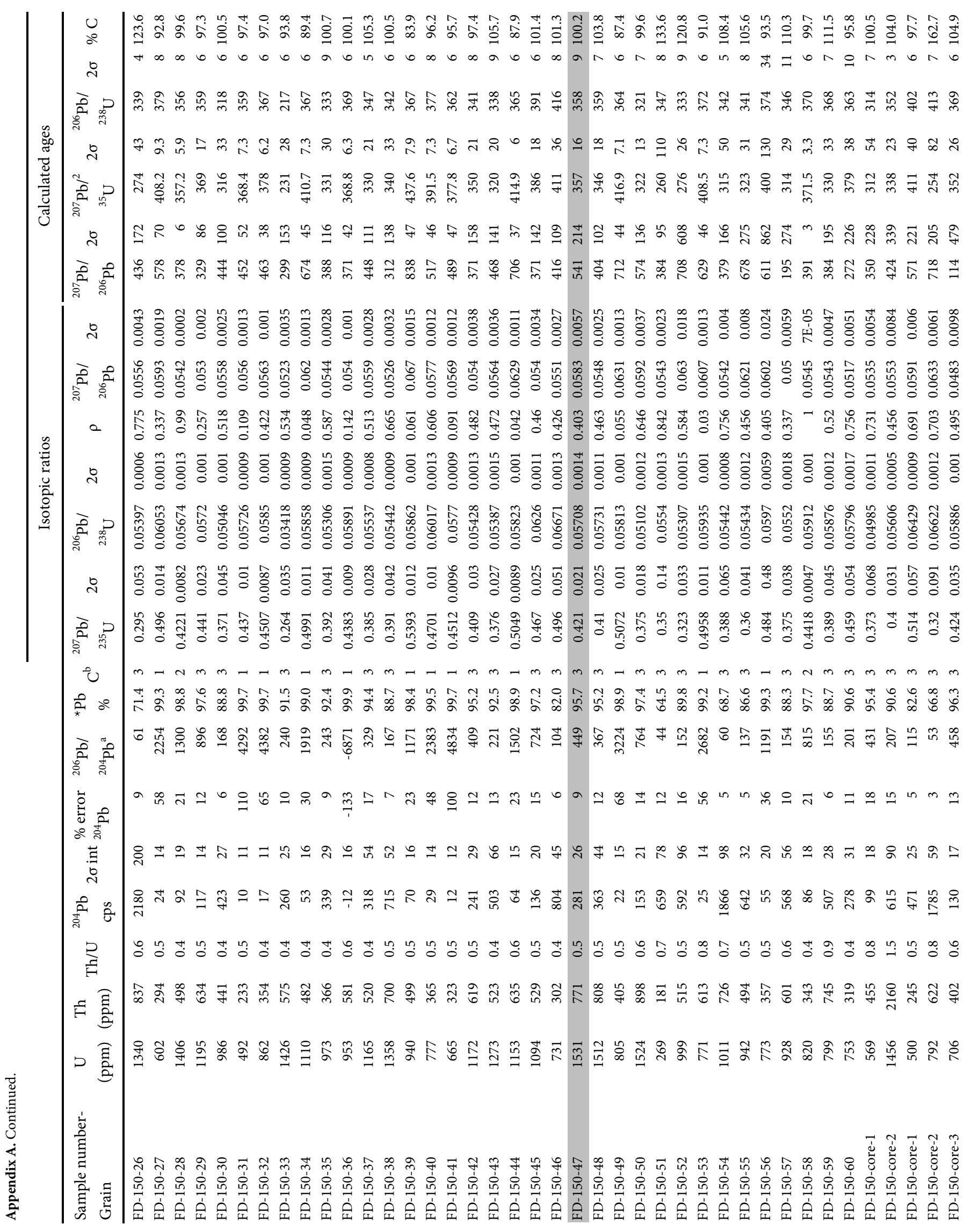




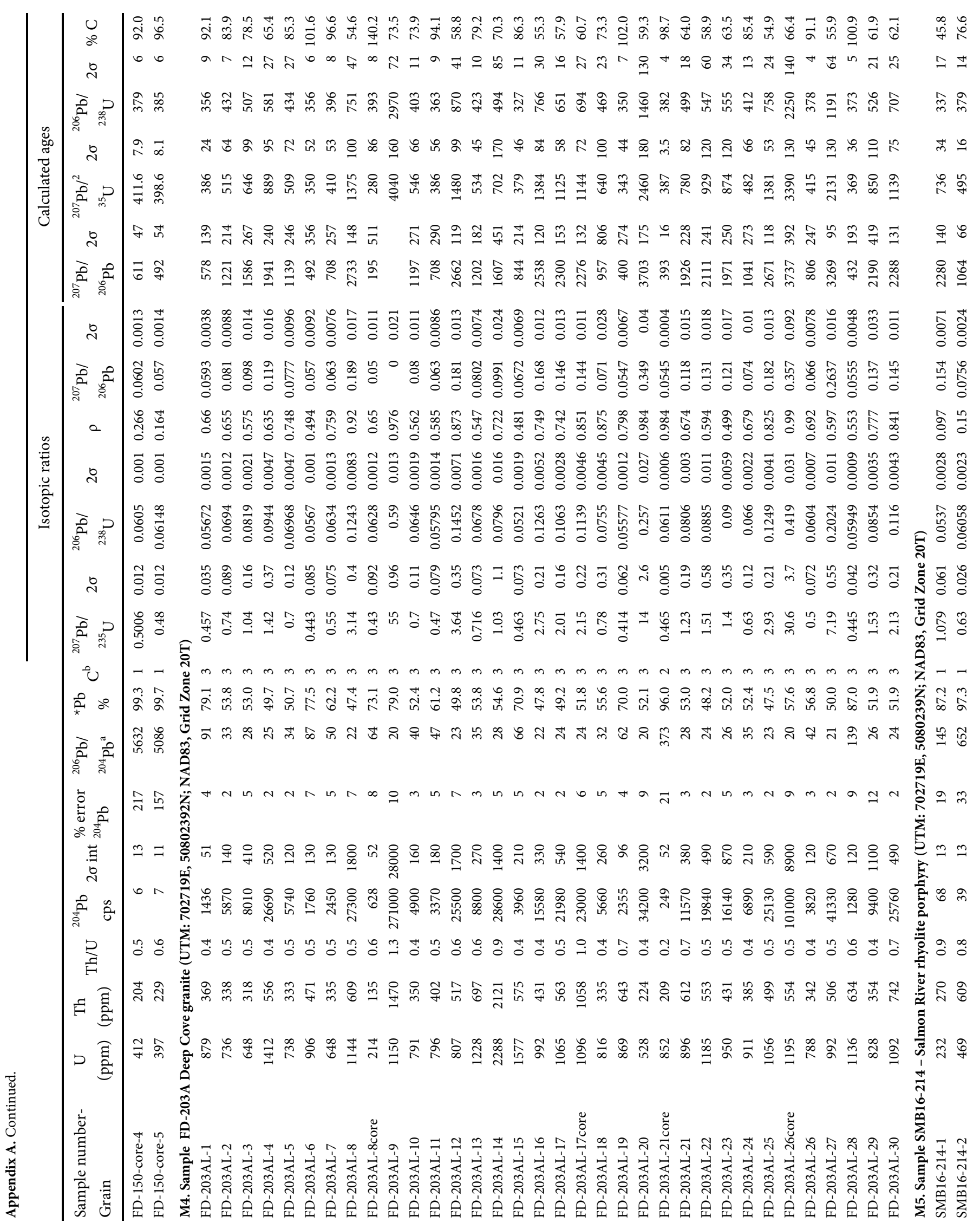




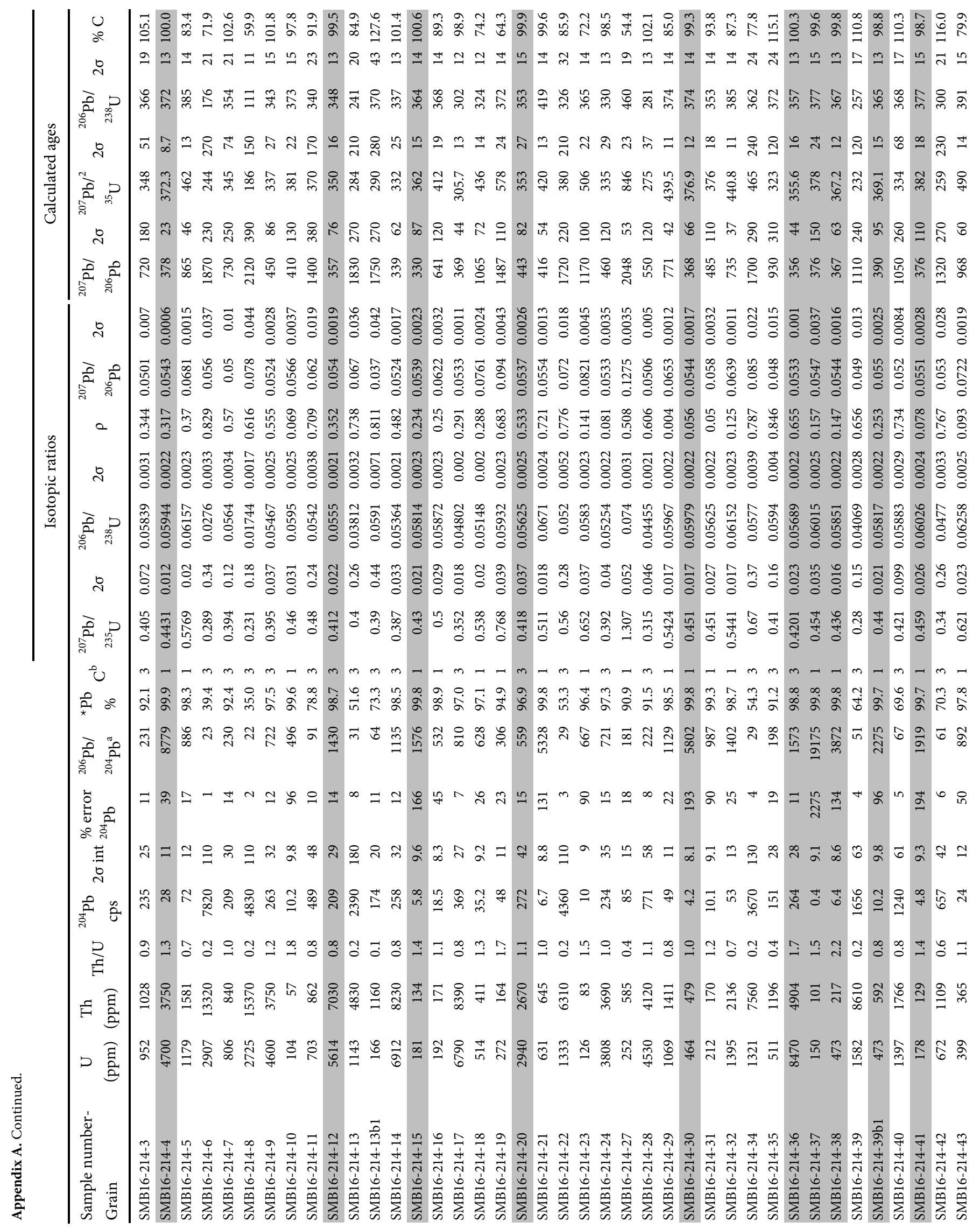




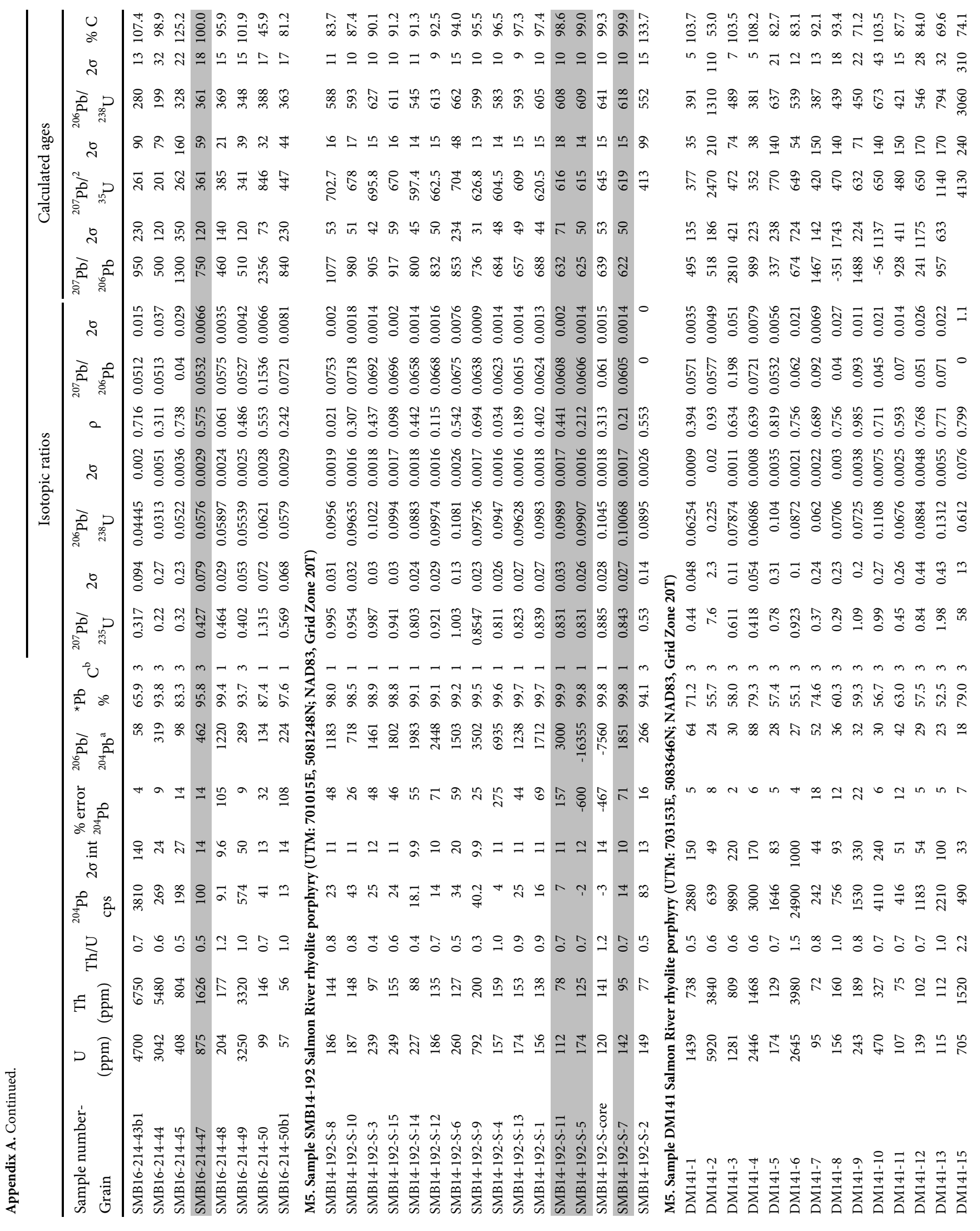




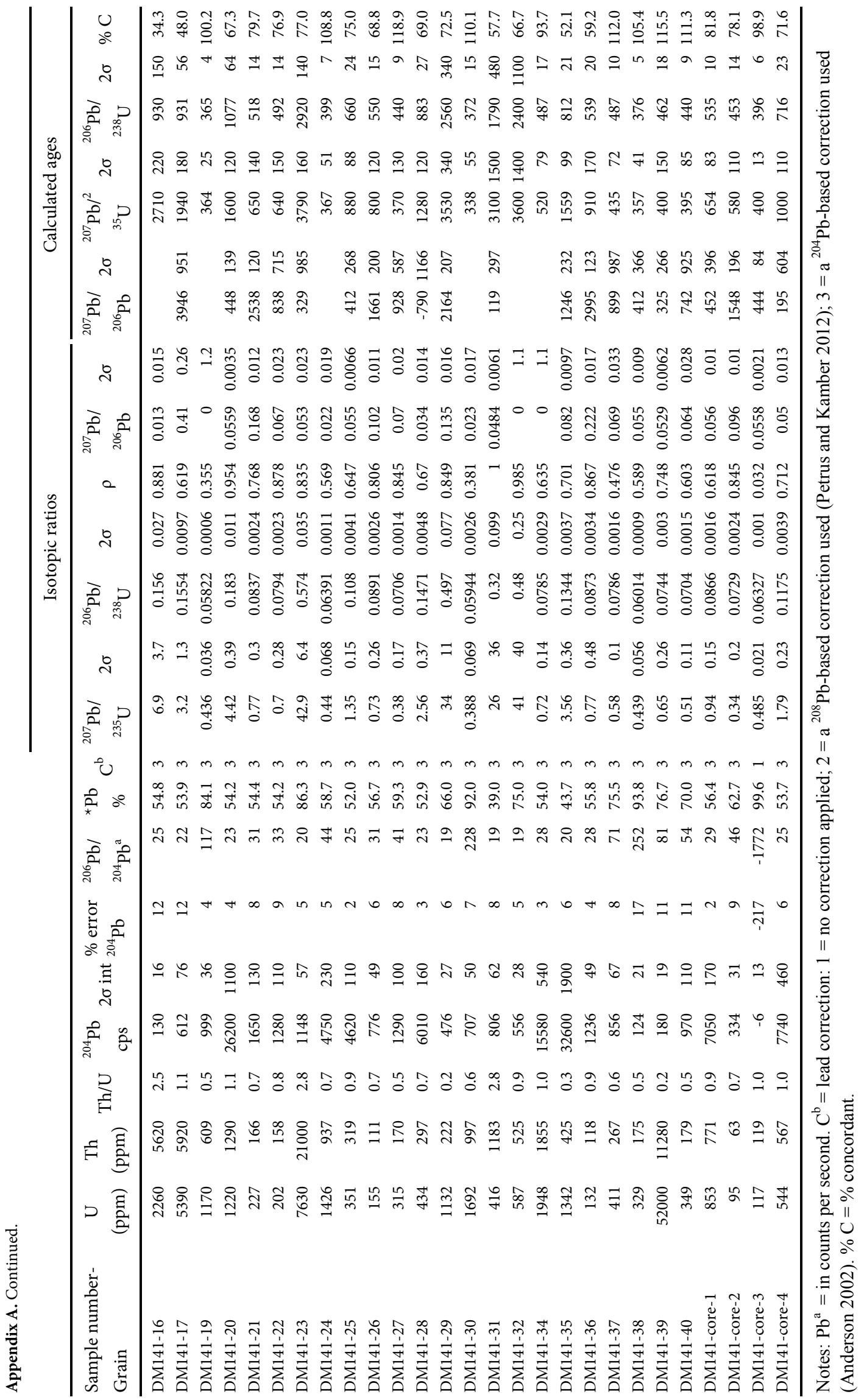




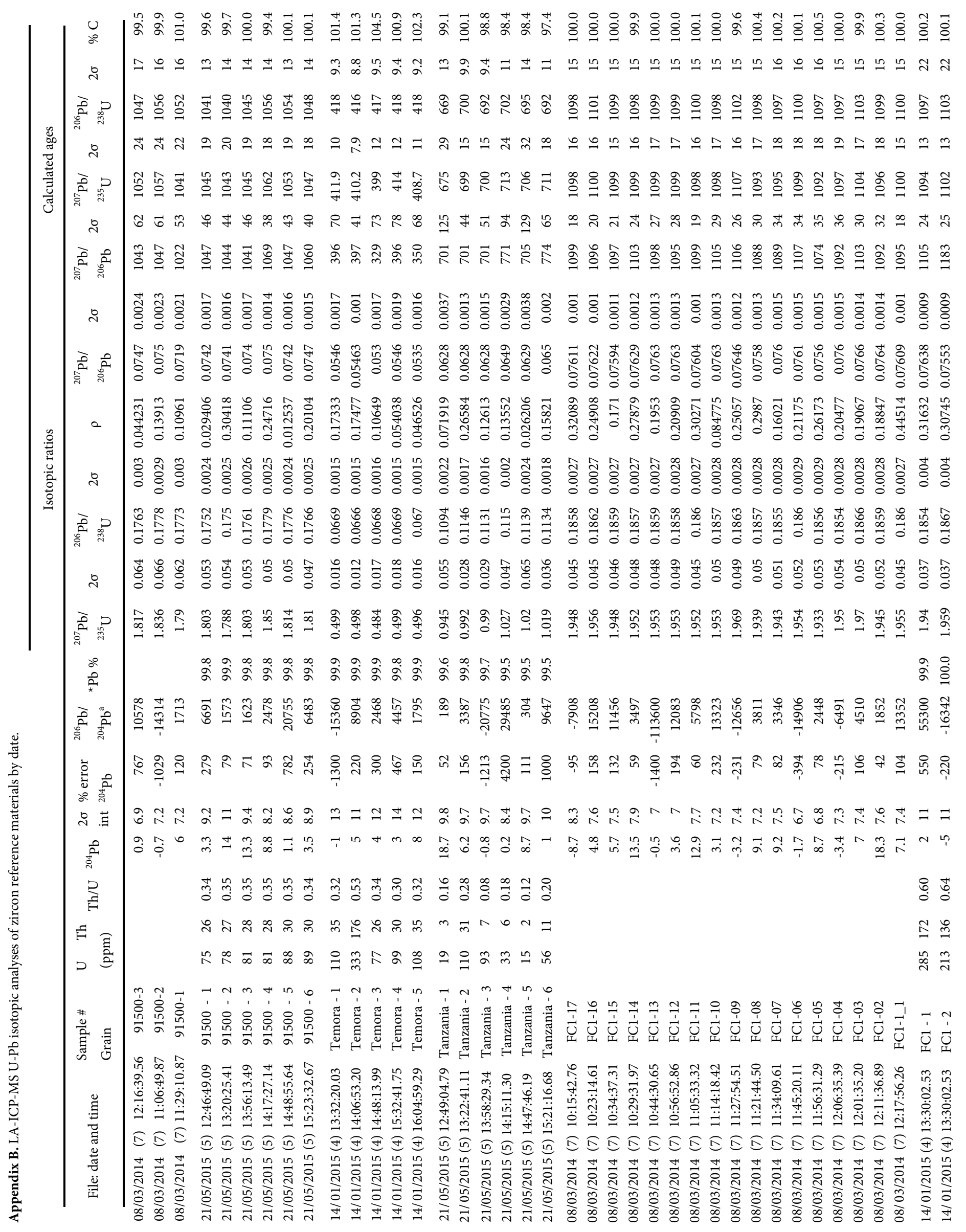




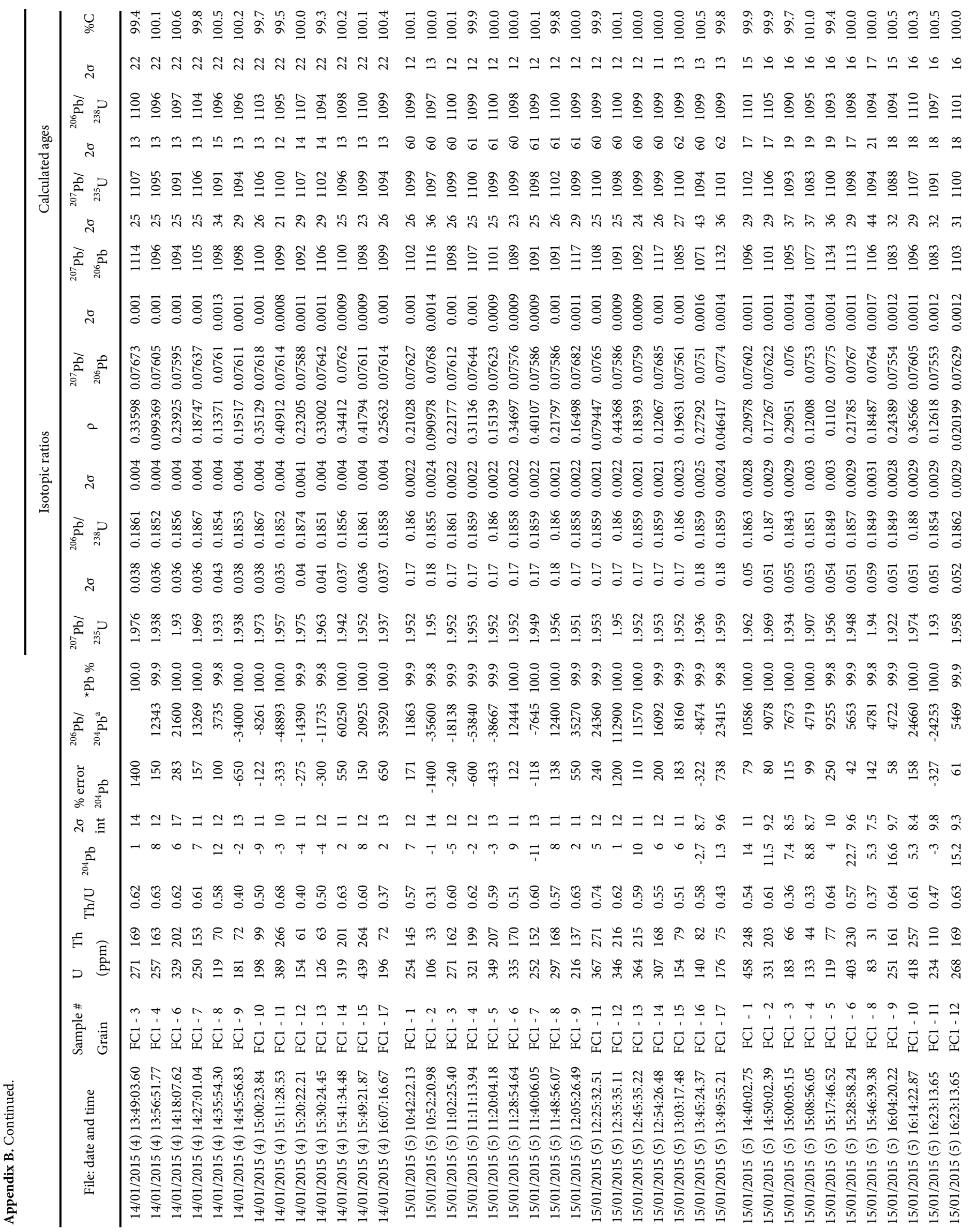




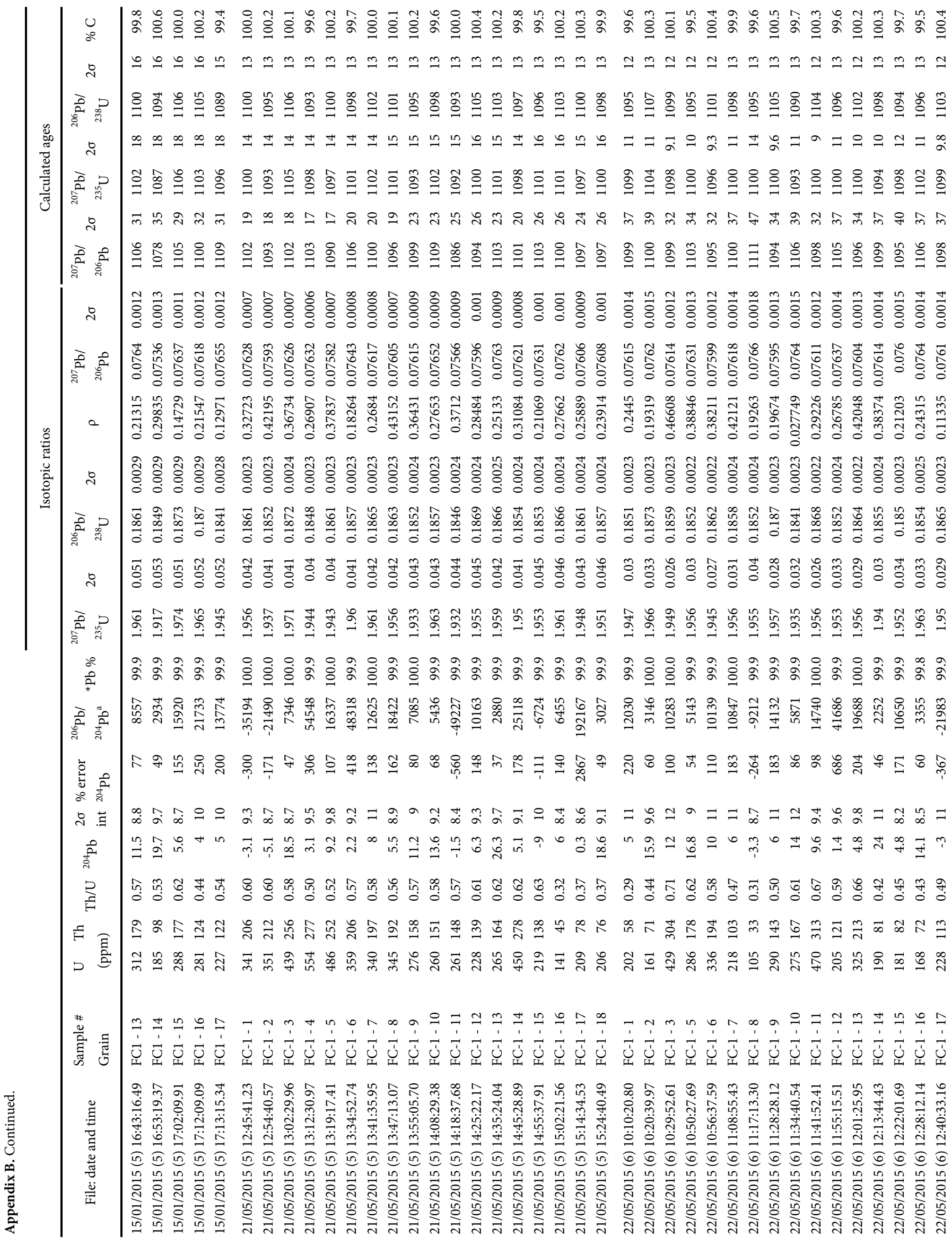




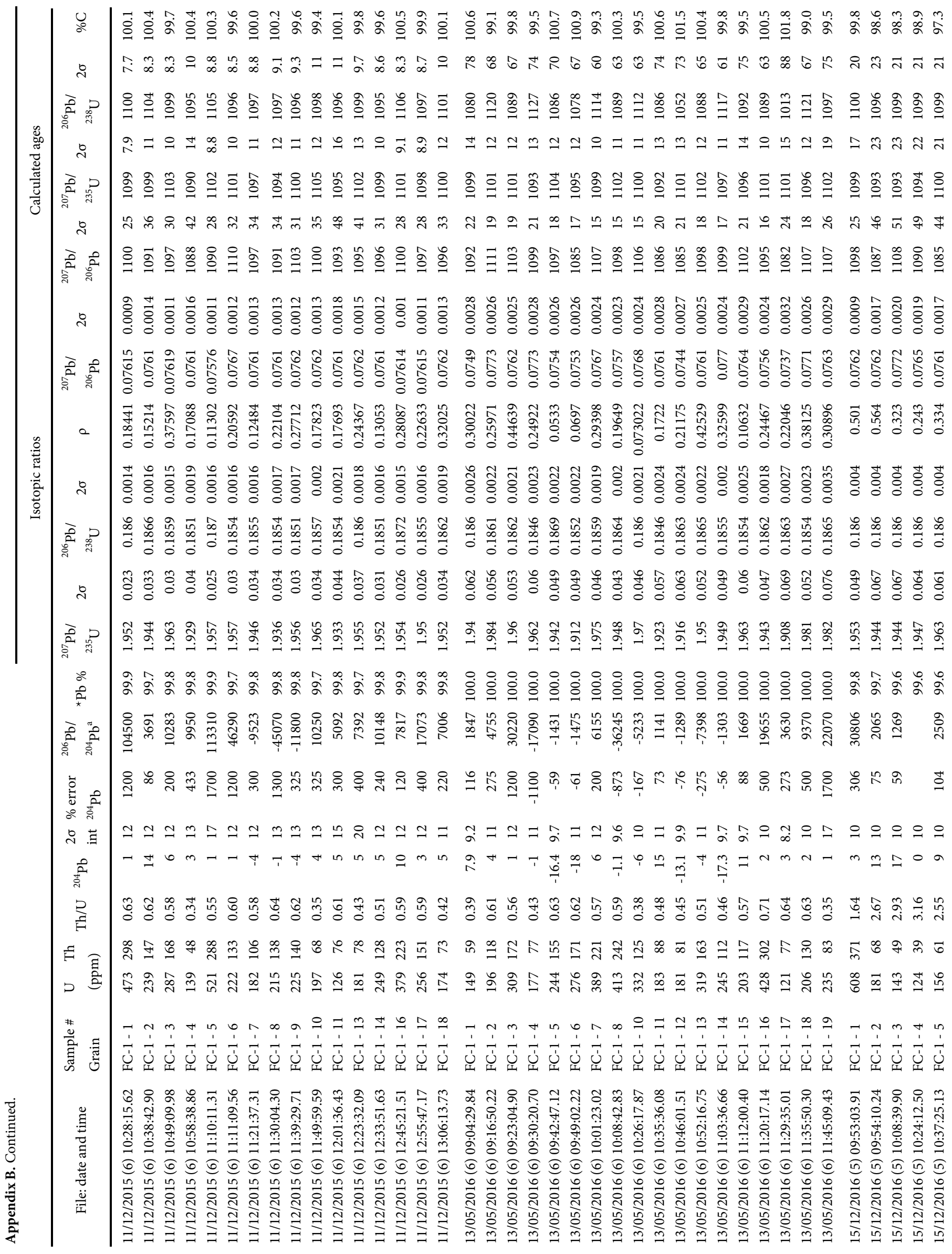




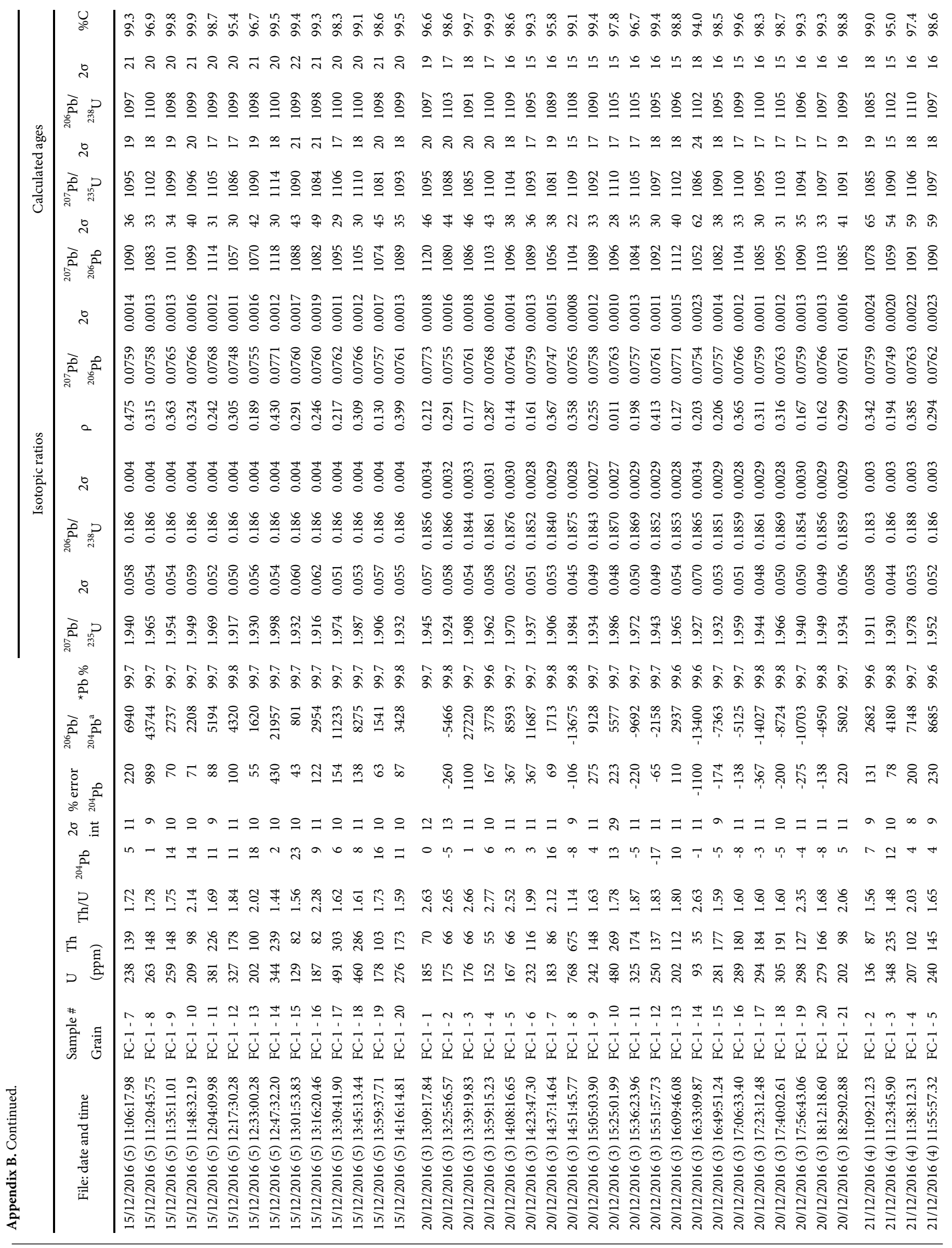




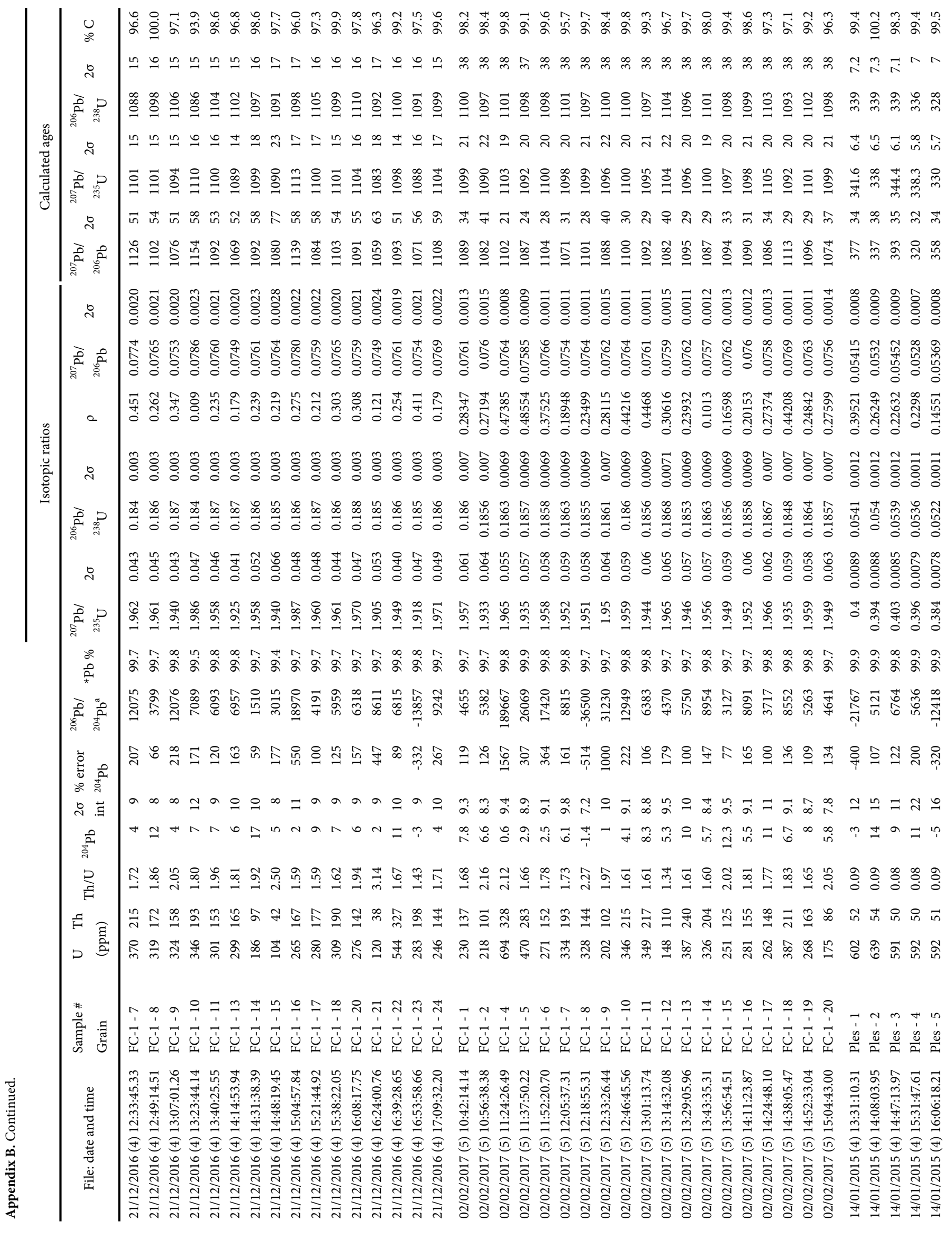




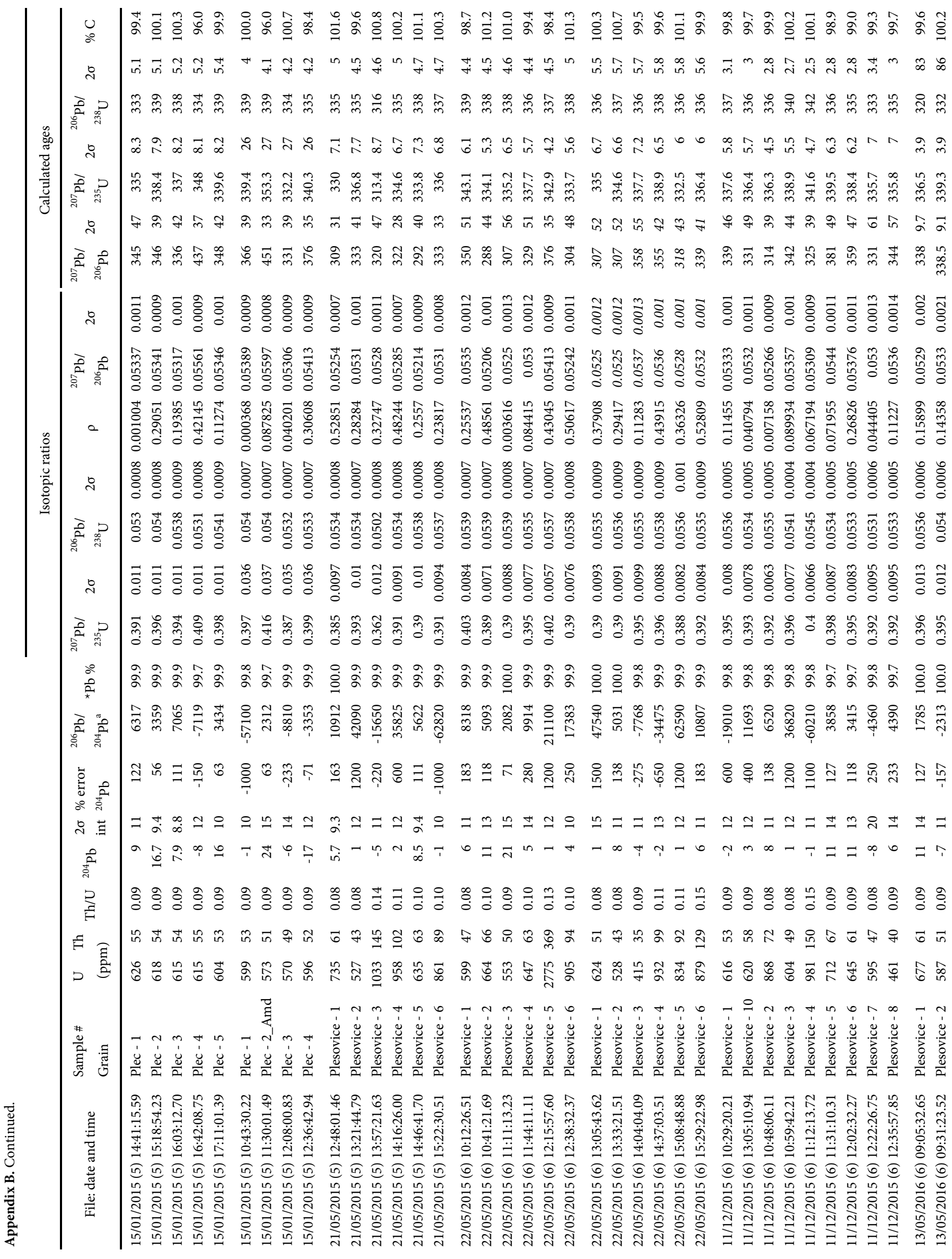




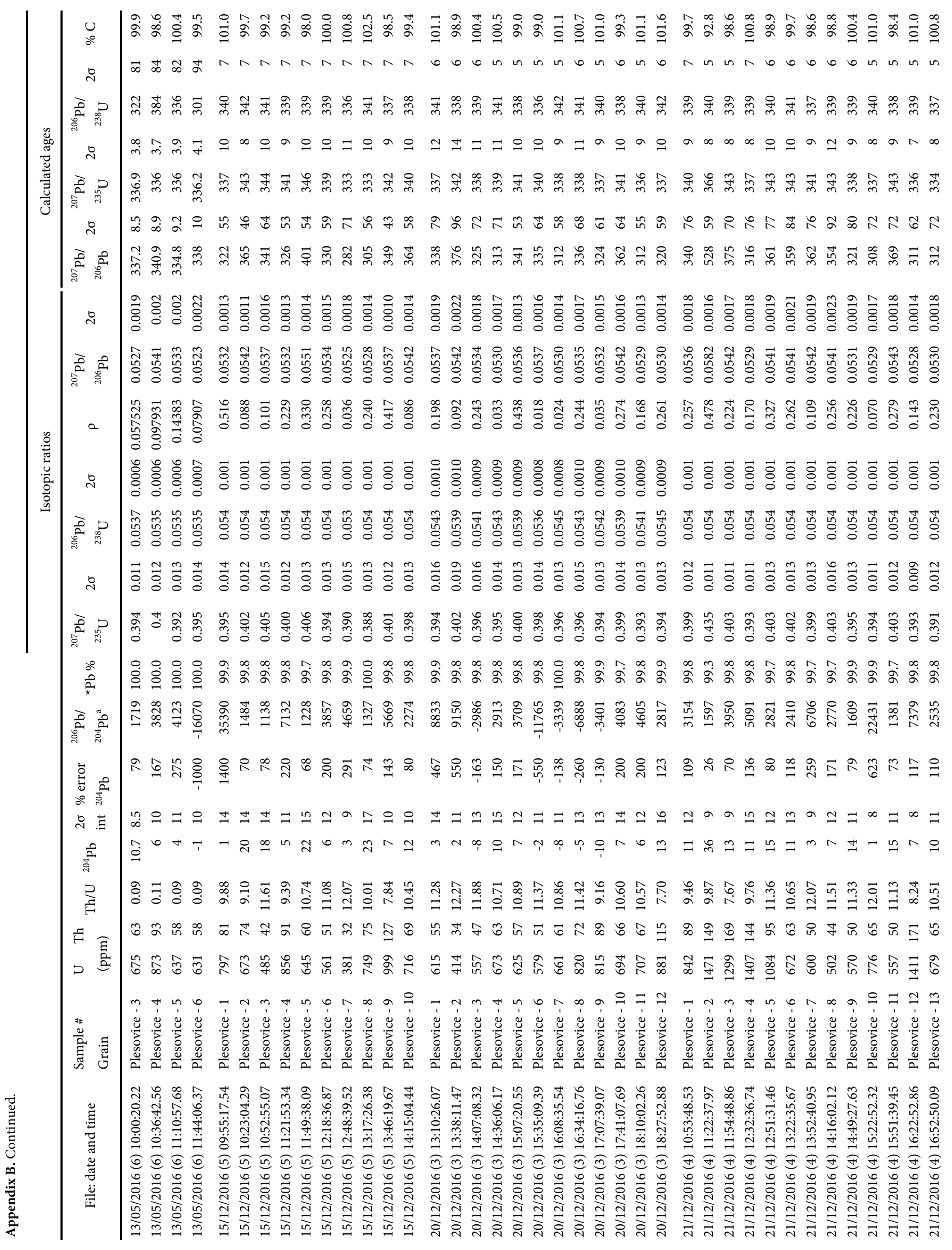




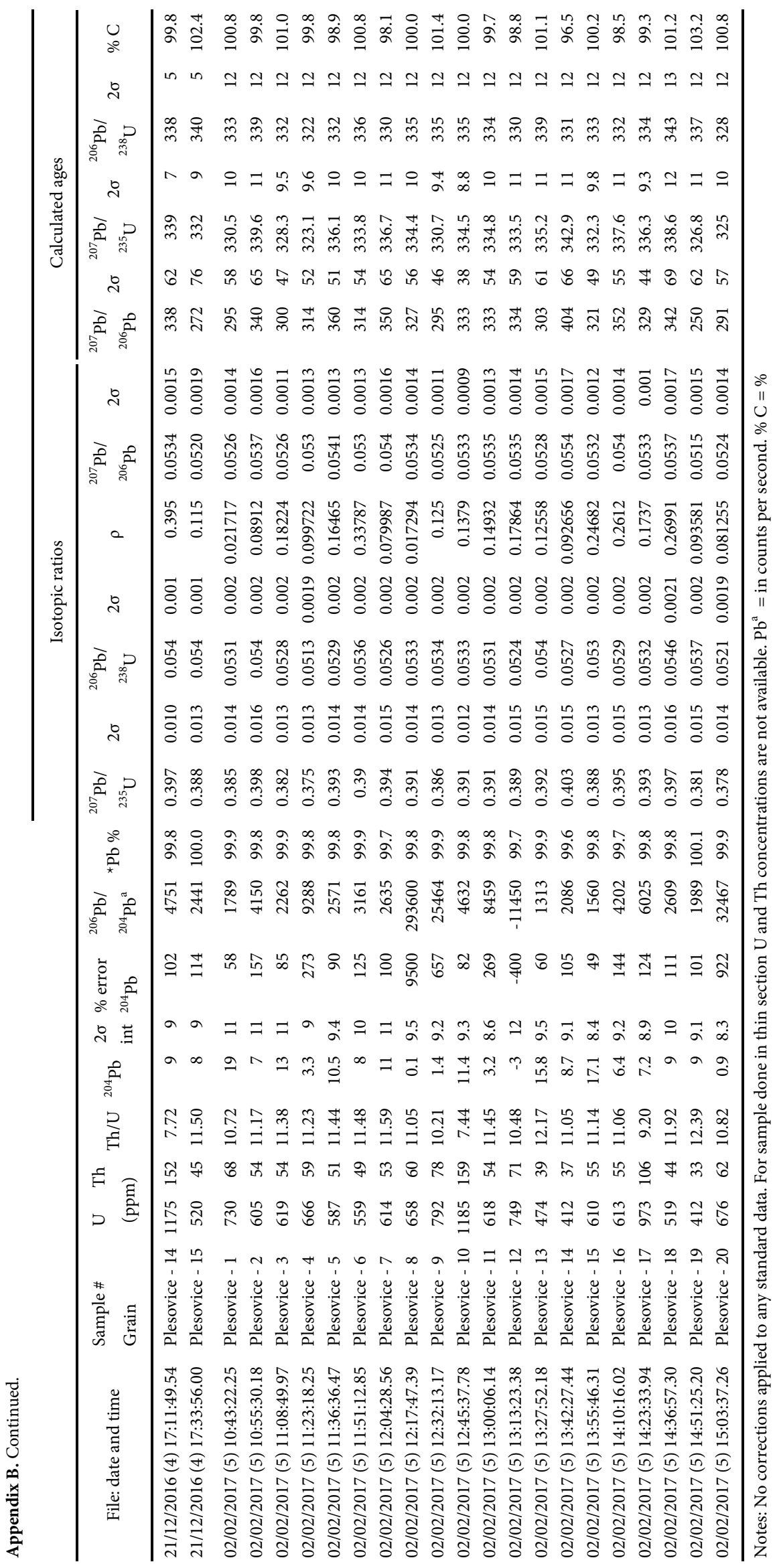

